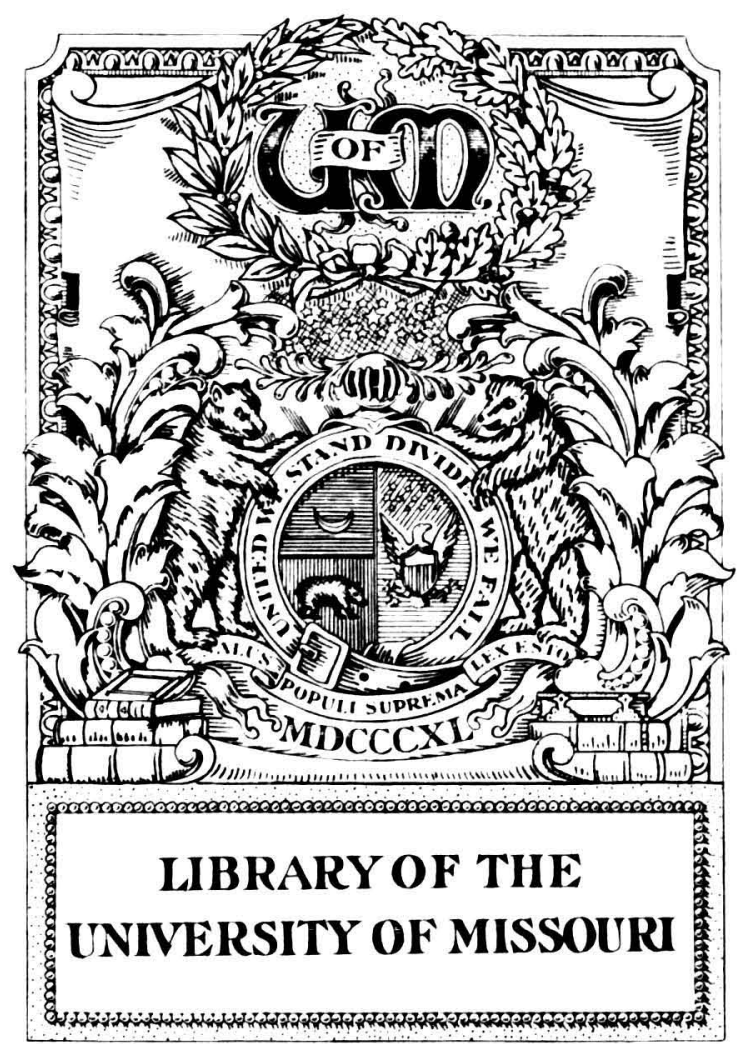


$7)$

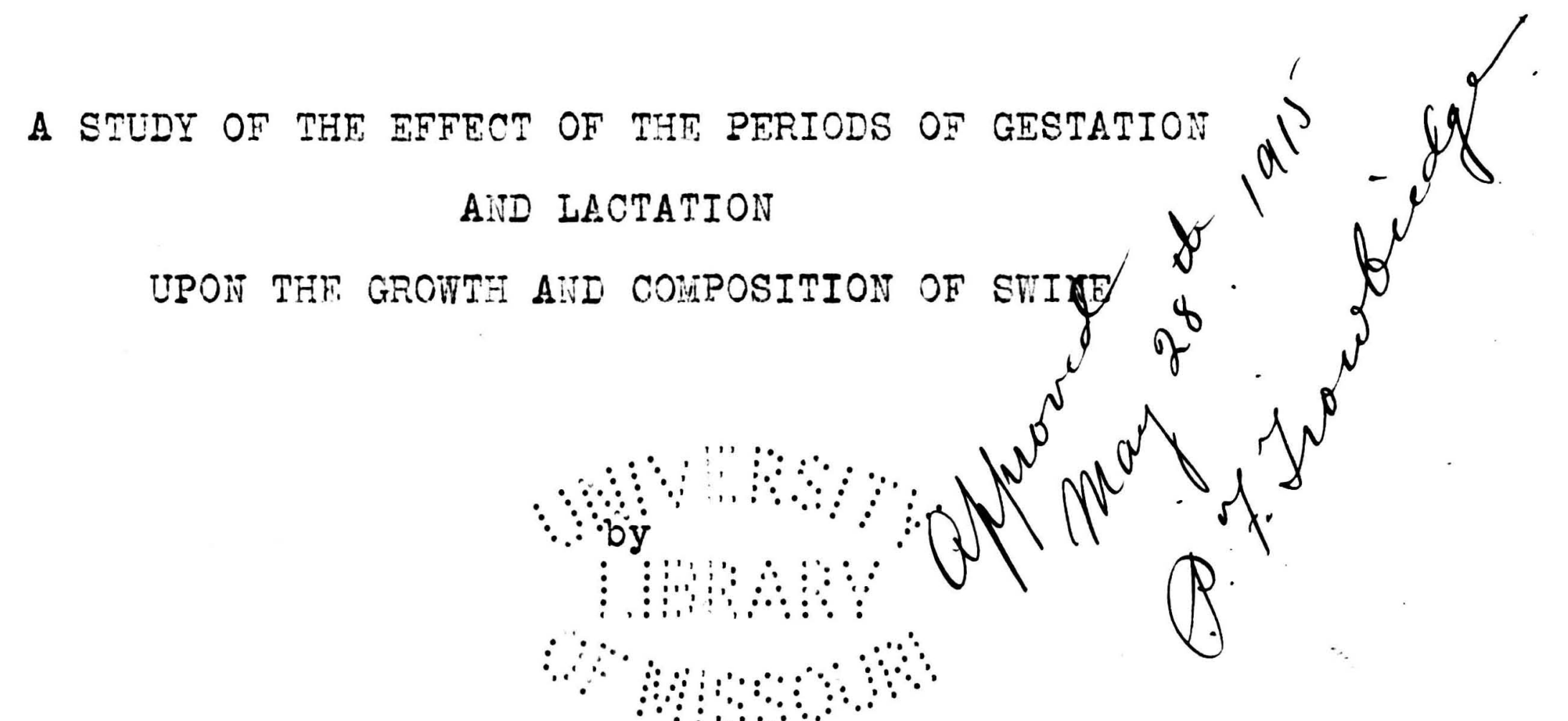

Daniel James Griswold, Jr., B.S.

SUBITTTED IN PARTIAL FUIFIILNFNT OF THE

REQUIRFIENTS FOR THE DEGREF OF

MASTER OF ARTS

in the

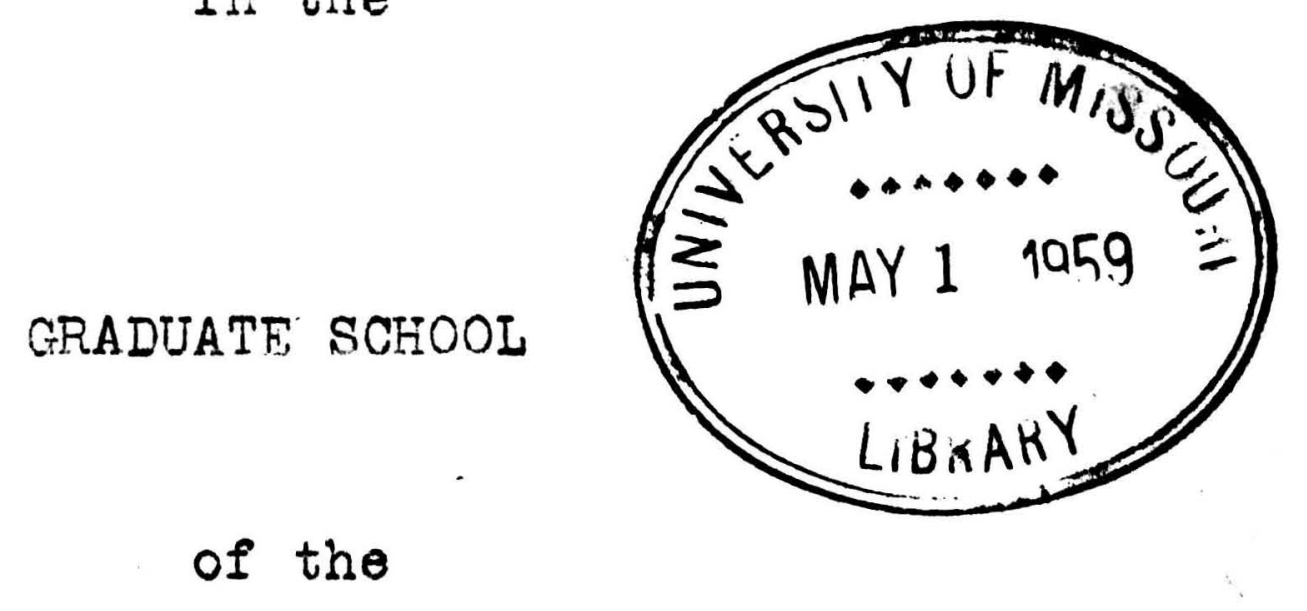

UNIVERSITY OF MISSOURI 
$378.7 \mathrm{M} 71$

$X G 889$

\section{Introduction}

Growth is at the base of organic production. In recent years an increasing importance has been attached to its study and to the conditions affecting it.

Davenport(1) says: "The importance of the study of growth cannot be over estimated. The maintenance of the human race depends upon that property which protoplasm alone displays of increasing 1tself for an indefinite time and to an indefinite amount. The supplies of the world are produced largely by growth each year. *****. The only thing then that limits growth is the limitations in the conditions of growth."

The same author (2) defines organic growth as increase in volume which may result from increase in volume of either the living substance or the formed matter of which organisms are composed.

It is well known that there are many factors that influence growth and development. Among these are light, temperature, moisture, oxygen supply, food, climate, season of year, age, and species. Among factors less easily analyzed and explained, but dependent in greater or less degree upon the foregoing, may be mentioned the inherent tendency to reach a certain size and form, cell actitities, and glandular secretions and excretions, Certain pathological conditions, pregnancy, and lactation may exert very marked influences on growth and development. The purpose of this study was to find the effect on growth of the conditions of pregnancy and lactation. It seems reasonable to expect that the production of 
milk would greatly check growth. The common observation of animals becoming thin in flesh while producing milk is sufficient evidence that the food is used for milk production even when there is not an excess over the amount the animal could use for the maintenance of its own body or for the increase of its own substance.

It is well established that under conditions of insufficient nutrition, material may be drawn from the tissues for the production of milk.

The effects of pregnancy are not so obvious. Unquestionably, the mother must provide the materials for bullding the new individual. Marshall( ${ }^{3}$ says there is evidence that in the early stages of pregnancy the materials, whatever their source and constitution, are broken down and partly resynthesized by the tropoblast, while later in pregnancy they are metabolized by the fetal cells themselves. This being the case, the maternal duties of the mammal do not include, in the latter part of pregnancy, the formation of fetal tissue-components, but only to the supplying of food and oxygen to and the removal of waste matter from the fetus, the frepacation of together with, an organ of nutrition for the new born young. Whether this material for the fetal tissues comes from the tissues of the mother or consists of unorganized substances absorbed from the food, its deflection to the fetus must check the growth of the mother, unless the physiological condition of pregnancy causes her to consume more food, enables her to 
digest a larger proportion of the food consumed, to better utilize the digested food, or causes her metabolism to be more economical.

\section{Historical}

It has been easy to find Iiterature on the subject of growth in general, and on the effects of pregnancy and lactation. Not a great deal, however, has been found dealing with the effects of these two conditions on growth, the greater part of the experimental work on this line having been done with mature animals.

Minot (4) has published the most complete work on this Ine of study that the writer has been able to find. His experimental work extended over a period of more than five years with a large number of guinea pigs. He used increase in welght as the sole criterion of growth.

From the weights of 66 mothers within three days after delivery of litters he found an average body weight of 588.0 grams. The corresponding weights of females not pregnant was 532.1 grams--an excess of 55.9 grams in favor of the gestating females. Taking 68 days, which he found the usual length of the period of gestation, the average dally gain of the pregnant females over the open females was about 0.8 grams. From another table of weights the average daily gain for guinea pigs of the same age thru the same number of days is not far from 1.8 grams. This indicates that the 0.8 grams daily excess Is a decided percentage increase. The impression is not left that increase is uniform thruout the period, but it is specific- 
ally stated that the percentage increase in weight is much greater in the last half of the period. Minot says that his observations confirm the conclusions of Edelfsen and Hensen $(5 t$ that female guinea pigs grow about the same whether they have young or not during their own growing period. He says "So far then as we now know gestation does not represent a tax upon the parent but a stimulus--it does not impede growth, but on the contrary favors it."'

No record is given of the amount of feed consumed by the pregnant and open animals, and therefore this work does not answer the question as to whether the increased gain in weight comes from a greater consumption of feed, better utilization of the feed consumed, or from a less expensive metabolism. Neither has it been determined of what the increased weight consists. Unpublished data from the Missouri Experiment Station shows that an animal may draw material from its tissues and replace it with water, thus keeping its body weight the same when there is an actual loss of dry substance. May this not be the case under the above circumstances? If such is the case, should the increase in weight be called growth?

To quote Minot further, 'It is probable that during gestation there is an accumulation of material in the mother's body which afterwards is exhausted for the production of milk."

It is well known that milch cows take on flesh while pregnant, especially when not producing milk, and become thinner after calving, even when consuming more feed than before parturition. 
Forbes ${ }^{(6)}$ in a review of the literature on phosphorus metabolism during pregnancy presents the following:

Hoffstrom (1910) studied metabolism of a woman during pregnancy, the subject receiving an ordinary mixed diet, and reached the following conclusions:

There was less phosphorus excreted in the urine during the second half of the period than during the first;

There was shown a greater tendency to hold back nitrogen than phosphorus; the average phosphorus storage was 0.331 grams daily, and the entire amount stored reached 56 grams at end of the period; of this amount 18 grams were deflected to the fetus, and consequently 38 grams retained by the mother organism itself.

E. Landsberg(1912) found in human pregnancy a retention of nitrogen four times as great and of sulfur and phosphorus twice as great as that required for the fetus.

Ver Eecke(1900) studied metabolism as affected by pregnancy in rabbits. He connected the decreased phosphorus outgo observed the last few days of pregnancy with the increase in activity of the mammary glands.

These experiments, together with many others, seem to establish beyond question that a pregnant female does store up material in her own body. This increased material does not, however, necessarily represent growth in the ordinary sense of the term.

That the production of milk may be a heavy drain 
upon an animal seems too obvious to require discussion. Oniy one instance of work along this line will be considered. Lusk(7) quoting from the work of Ostertag and Zuntz, says that a sow may yleld milk rich in fat, 12.9 per cent, and in such quantity that the energy content may arount fo from two to five times that required for the mother sow's metabolism. What effect has this drain upon the growth of immature mothers.? Does it retard or stop growth, or is there ''a surplus or reserve capacity for assimilation"' which "would be called in to meet the demand, and the parent organism meanwhile kept on growing as before."? Minot (4) thinks that such is the case in pregnancy, because he found young females that had produced

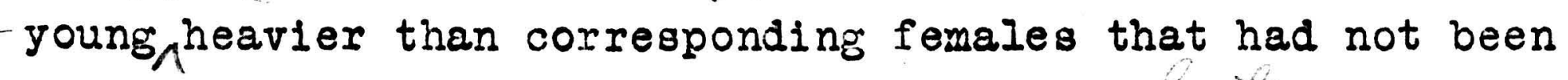
- pregnant; yet he found these same females lose weight while in lactation. Must we then conclude that young females grow when pregnant and ''ungrow'' while producing milk? Evidently some other measure of growth than the weight of the animal is needed. That an animal may remain at constant weight and yet grow has been established,by actual measurements.of cattle at the Missouri Experiment Station. 


\section{Purpose of the Experiment}

The purpose of the experiment is to study the effect of the periods of gestation and lactation on the growth and composition of swine. To gain most from such a study it is necessary to eliminate as many as possible of the other factors that influence growth and compositon. How it was attempted to eliminate these factors will appear in the plan and progress of the experiment.

\section{$\underline{\text { Plan }}$}

The plan yas to secure ten spring gilts as nearly uniform in breeding, age, size, and condition as possible. To breed some of them and to leave others open--all other conditions to be as nearly uniform for all animals as possible. The growth was to be determined by individual dally weights, and measurements, together with the slaughter and analysis of representative animals at the beginning and at the close of the perlods. Plctures were to be taken also.

All the ge gits were to be kept on the same ration for two or three weekgh when one was to be slaughtered as a check animal, six of the gilts were to be bred as soon as possible, and the other three left open as checks. To eliminate the effect of different amounts and kinds of feed, all animals were to be given the same ration thruout the experiment, except for differences in the amount as given below. All were to recelve the same amount of the same ration thruout the period of gestation, the aim being to secure good thrifty growth without fattening. After farrowing, the gilts 
suckling pigs were to receive all the feed they would consume, except one whose ration was to be limited to the amount consumed by the open gilts.

At the close of the gestation period one gilt was to be slaughtered just before farrowing, one just after farrowing, and at the same time one open gilt as a check. The pigs were to be taken from one gilt that she might have the effect of the period of gestation without being subject ${ }_{\lambda}^{-e d}$ to the drain of lactation.

At the close of the lactation period, or when it was considered that lactation had made its greatest drain, there were to be slaughtered one open gilt, the one that had produced a litter but had had no period of lactation, the one that had suckled her litter on a limited ration, and one that had suckled her litter on full feed.

After the close of the lactation period, the open gilt left, and the remaining one that had suckled pigs were to be given full feed untll the latter reached market conditon, when they were both to be slaughtered for analysis.

It was also planned to run digestion trials in each period to compare the digestion coefficients of the open and pregnant gilts and of suckling and non-ouckling gilts.

As was anticipated might be the case, conditions arising in the progress of the experiment made it seem advisable to change some of the details of the plan. While the general plan has been adhered to, such changes were made as seemed best to take advantage of varying conditons which it was imposible to control. 


\section{The Experiment}

Ten Duroc Jersey gilts were secured. Five of these, numbers $1,2,3,4$, and 5 were litter sisters farrowed laroh 1 , 1914. Of the other five, numbers 7 and 8 were litter sisters, farrowed March 23; number 6, farrowed Larch 24 was from a dam that was a full sister of the dam of numbers 7 and 8 ; numbers 9 and 10 were also litter sisters farrowed March 7. All ten gilts were from the same sire.

Numbers 1, 2, 3, 4, and 5 had been fed corn and tankage with oats and rape for forage. The others had been fed corn and tankage on blue grass pasture.

These gilts were delivered at the State Farm October 6, 1914, and were at once given the single serum treatment against cholera. They received this treatment about every sixty days thruout the experiment.

Individual cots, 6 ' $X$ 6' with a sloping roof 4 feet high in front and $21 / 2$ feet high in rear, were placed facing southward, at the north end of pens $91 \times 30$. There is a door in the front of each cot and at top of front side an open window I'X 4', covered with woven wire. The cots have wooden floors and are well made so that they afford good shelter. When the weather became cold, wheat straw was allowed for bedding, and the animals were kept quite comfortable except in the very severest weather. The pens were fenced with 30 inch woven wire with a 6 inch board at top and bottom. Back of the cots was an alley way, from which hurdles were used to set up a runway to scales. These quarters were located on an east hill 
slope where the drainage was good.

The diagram shows the arrangement of pens and coti.

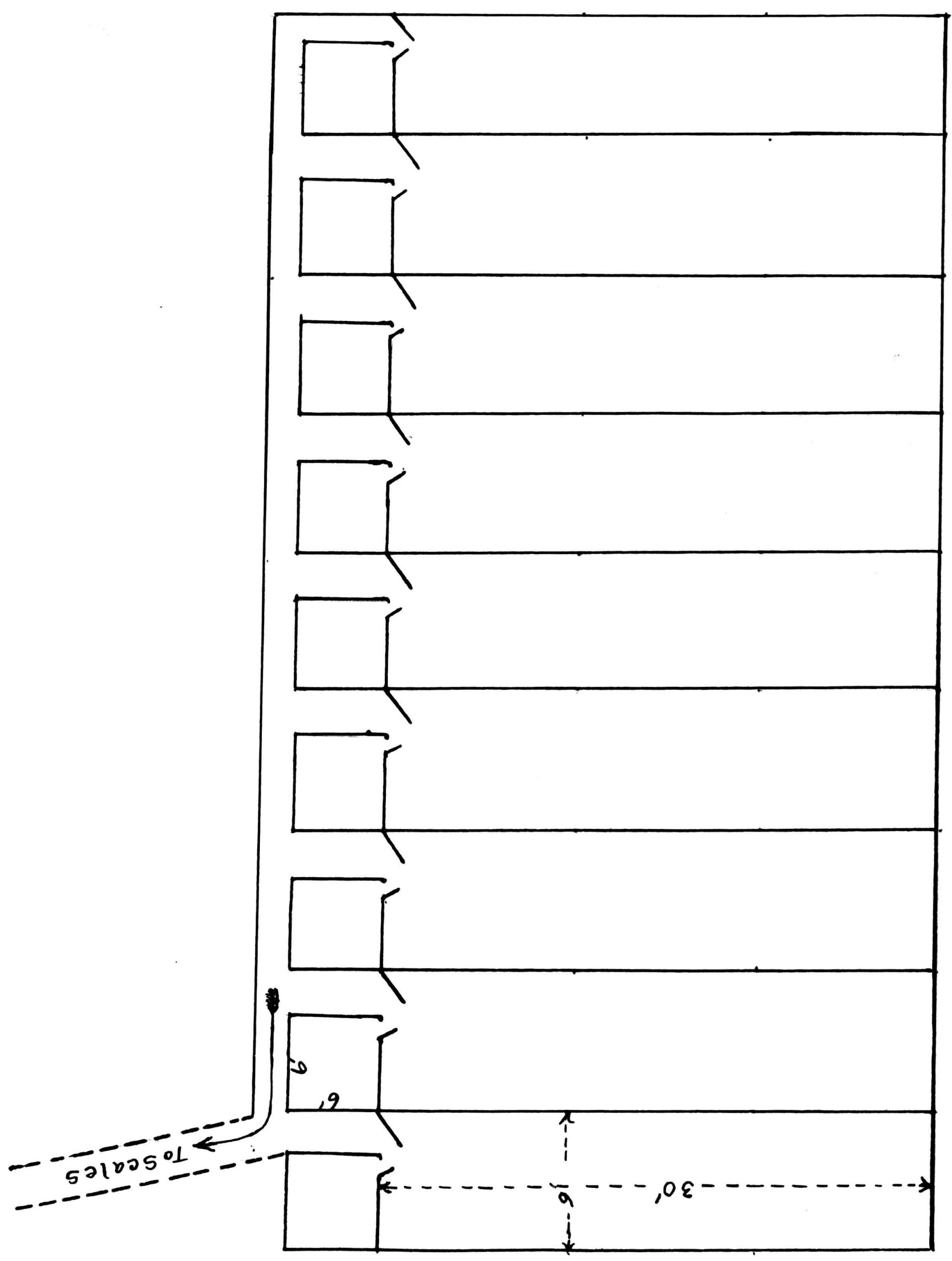


October 8th the animals were placed in separate pens except that Nos. 9 and 10 were kept in the same pen until October 29th when they were separated. From this time each gilt was kept in her own pen all the time so that one could not plok up the droppings of another and thus vary the amount of food ingested.

The pens had been cleared of regetation except for weed and grass roots in the soll. Shortly after the gilts were placed in the pens rains made the ground very soft and the gilts did much rooting, working the soll over very thoroly. After the first few days there was no organic matter left for them to get. All were rung october 14 th. They were sprayed occasionally with oil to free them from lice. A worm eradicator was given two or three times in the feed. This consisted of

3 parts sal soda

3 " Glauber salts

3 i' copperas

3 ' common salts

1 part sulfur

The ration chosen consisted of 4 parts ship stuff, 2 parts corn chop, 2 parts wheat bran, and 1 part linseed meel, old process. This ration has a nutritive ratio of about 1 to 4.5, and is perhaps a better ration for growing or breeding animals than hogs in dry lots usualiy get. According to Forbes $(8)$ this ration probably does not contain enough ash for maximum growth, but it was not the aim of this experiment to study the animals kept under the most favorable conditions 
possible; it was considered better rather to keep the animals under 'good average' conditions. Furthermore, the use of this ration would permit of closer correlation of the results of this experiment with other work in animal breeding at the Missouri Experiment Station.

It was considered impracticable to feed the same amount of feed per hundred pounds live weight, but each gilt was given the same amount. They were fed twice each day. The amount given at first was 4 pounds each dally of the mixed feed, but after two days a few of them did not eat all the feed and the amount was reduced to 3.4 pounds daily. This amount was gradually increased, the aim being to secure good thrifty growth without fattening. The feed was weighed and put in the troughs dry, then water added to molsten thoroly-the animals being shut in the cot while the feed was being prepared. They ate the feed readily and wasted very little, after the feed was eaten, water was put in the troughs that each gilt might have all the water she desired. Salt was given in the feed from time to time.

The gilts were weighed dally after the morning feed, and before they had drunk any water except that given in the feed. The first weighing was october 10th, in the afternoon. The weights were as follows! No. 1, 135 pounds; iNo. 2, 165 pounds; No. 3, 160 pounds; No. 4, 164 pounds; No. 5, 154 pounds; No. 6, 114 pounds; No. 7, 143 pounds; No. 8 if6 pounds; No. 9, 140 pounds; No. 10, 122 pounds. The average welght was 141.3 
poundr; the difference between the largest and smallest was 51 pounds.

\section{Measurements}

The measurements were taken about every thirty days as follows:

1. Height at withers

2. Helght at croup

3. Width of shoulders

4. Width of shoulder points

5. Width of hams

6. Width of ham points

7. Width of head.

This measurement was taken with calipers at the bones just below and back of the ears.

8. Heart girth

9 Paunch girth

10. Flank girth

11. Length of body

This measurement was taken from the first long process of the spinal column, at the withers, to the tall head.

12. Depth of chest

13. Circumference of front cannon bone at smallest place.

14. Circumference of rear cannon bone at smallest place.

15. Distance from elbow to ground

16 Distance from shoulder point to ground. 
In addition to the above measurements an adjustable chain was used to get the contour of the body at the heart girth, at the paunch girth, and at the flank girth. The first measurements were taken October 18th.

Plctures showing side and rear view of each animal were taken at the beginning of the experiment, at the close of gestation, and at the close of the lactation period. The first pictures were made October 28 th.

October 29 th, the first check animal, No. 4, was slaughtered for analysis. The importance of choosing for this check an animal as nearly typical of the whole group as possible was recognized. Mr. L. A. Weaver of the Animal Husbandry Department was asked for assistance and selected iNo. 4 as probably best meeting the requirement.

After the slaughter of No. 4, No. 9 was put into the vacant pen, and it was considered that the experiment was really begun.

The preliminary period, from October 6th to October 29th, is of considerable value because the animals were all getting the same amounts of the same ration. It seems that this period, twenty three days, is long enough to eliminate, or at least greatly reduce, any differences in capacity for growth or utilization of food due to the slight difference in the previous ration. It also serves to indicate differences in the animals due to individuality. To show how nearly uniform were their gains in weight the following table is presented. 
The top line of figures shows the weights in pounds October/0th, The second, the weights October 29 th, and the third line, the gains.

$$
\text { Table no.l. }
$$

No. No. No. No. No. No. No. No. No. No.

$\begin{array}{llllllllll}1 & 2 & 3 & 4 & 5 & 6 & 7 & 8 & 9 & 10\end{array}$

$\begin{array}{llllllllll}135 & 165 & 160 & 154 & 154 & 114 & 143 & 126 & 140 & 122\end{array}$

$\begin{array}{llllllllll}145 & 173 & 173 & 163 & 164 & 124 & 160 & 138 & 155 & 135\end{array}$

$\begin{array}{llllllllll}10 & 8 & 13 & 9 & 10 & 10 & 17 & 12 & 15 & 13\end{array}$

The average gain for this period is 11.7 pounds, 0.6

not far from pounds per day. No. 7 shows a tendency to put on more weight than the others.

After the slaughter of the check, the gilts were bred as soon as possible, on the following dates; No. 3 , November 6; No. 9, November 12 ; No. 5, November 15 ; No. 2 , November 18; No. 1, November 23; and No. 7, December 4. December 26 th No. 7 was again in heat, but was very lame (one hind leg being broken) and it was decided to breed another gilt instead. No. 8 was bred December 30 ,

Beginning January 23rd a ten day digestion trial was run with two pregnant gilts, Nos, 5 and 9 , and two open gilts, Nos, 6 and 10.

It was decided best to let conditions determine which gilt should be slaughtered just before farrowing, which just after farrowing, and which should be allowed to suckle litters. March lst, No. 3 farrowed seven pigs, only two of which were alive. Since this made her litter so small it was decided to slaughter her as the one just after farrowing, 
and she was slaughtered March 2nd. The two live pigs were killed for analysis also.

No. 7 had apparently completely recovered from her injury, her apparent good condition and her gain in weight indicated that she might be used as a check at the close of the gestation period. Accodingly, she was killed at this time. It was found however that she was pregnant, having four pigs in utero. Dr. L. S. Backus of the Veterinary Department was consulted and he decided, after examination, that conception had occurred at the time of breedine, Iecember 4 th. This being the case, the gilt was 88 days in pregnancy. This made it necessary to slaughter another animal as a check at the close of the gestation period. No. 10 was slaughtered Jarch 9 th.

No. 9 farrowed liarch 5th. She produced five ples, but one became chilled so that it died. She killed another, lesving only three. March 10th No. 5 farrowed, producing six pigs. Niarch 13th No. 2 produced three pigs, one of which was only about half normal size and lived only about two days. The morning of March 14 th the three pigs were $\uparrow$ (3) 2 1 . 
only two pigs. She has never seemed to produce much milk.

No. 9 suffered some inconvenience from inflammatior. of the marnary glands for a few days, but soon appeared to be normal and was continued thru the lactation pertod of the other EiIt as being the nearest practicable approach, under the circumstances, to a gilt having the effect of pregnancy for the full period and without the drain of lactation.

April 15th, 106 days after breeding, No. 8 produced five pligs, one of which was dead. The others lived only two days. Postmortem showed they were not fully developed. It had seemed best that iNo. 8 should be carried to market condition after the close of her lactation period, but since her litter was lost it was decided best to slaughter her for analysis as another animal slaughtered after farrowing. She was slaughter $\in d$ Aprid 17th. One pig was found in utero.

March 14th after the three pigs were taken from No. \& and given to No. 3 there were the two gilts with iltters, No. 5 with her own six pige and No. 2 with five pies, two of which were her own. It was decided to feed No, 5 all she would eat and Iimit the ration of $N 0.2$ to the amount that the open gilt would consume. It was impossible to get No. 5 to eat very $\int$ more feed than the non-suckling gilt would eat. She never ate more than 6.6 pounds and that much only for one day. The others readily ate 6 pounds daily and would have eaten some more. April 5th No. 5 went off feed with a severe attack of scours, and was not back on full feed until April Ilth. In this period she ate less than half her usual amount. She was separated from her pigs except for a few minutes at a time See page 90 
No. of Gilt

Date of Birth in 1914

Age in days when rec'd Oct. 6, 1914,

Welght when weighed at Station, 0ct. 10,

Teicht on Oot. 20 when wo.

slaughtered, pounds.

Gain in weight from Oct. 10 to oct. 29 , pounds

\section{Date of Breeding}

Age at Breeding, days

Welght at Breeding, pounds

Date of Farrowing, 1915

Age at Farrowing, days

Welght just before Farrowing, pounds

Weight just at close of Farrowing, pounds

Number of pigs

We1ght of litter, pounds

Number of pigs suckled thru lactation

Welght at close of lactation

\section{Date of slaughter}

Age at time of slaughter, days

Weight at slaughter, pounds

No. of days on from Oct. 29th

Gain in weight from Oct. 29th to slaughter

Averoge gain in we1ght per day Pou ds.

ISee page 16 ¿6ee page $17{ }^{3}$ See page 16

\section{I}

2

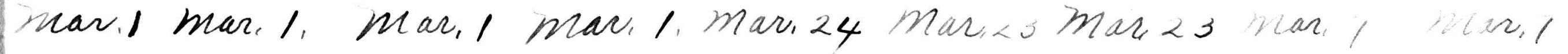

$\begin{array}{llllllllll}220 & 220 & 220 & 220 & 220 & 191 & 198 & 198 & 214 & 214\end{array}$

$\begin{array}{llllllllll}105 & 165 & 160 & 154 & 154 & 114 & 143 & 126 & 140 & 122\end{array}$

$\begin{array}{llllllllll}145 & 173 & 173 & 163 & 164 & 124 & 160 & 138 & 135 & 133\end{array}$

$\begin{array}{lllllllll}10 & 8 & 13 & 9 & 10 & 10 & 17 & 12 & 13\end{array}$

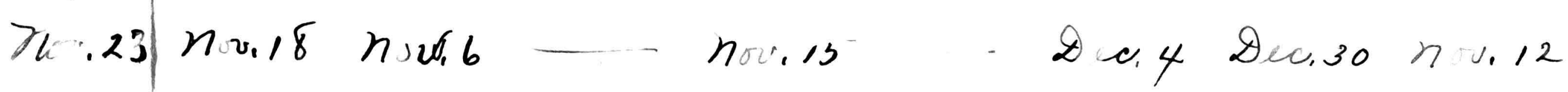

$\begin{array}{lllllll}268 & 263 & 251 & 260 & 257 & 283 & 253\end{array}$

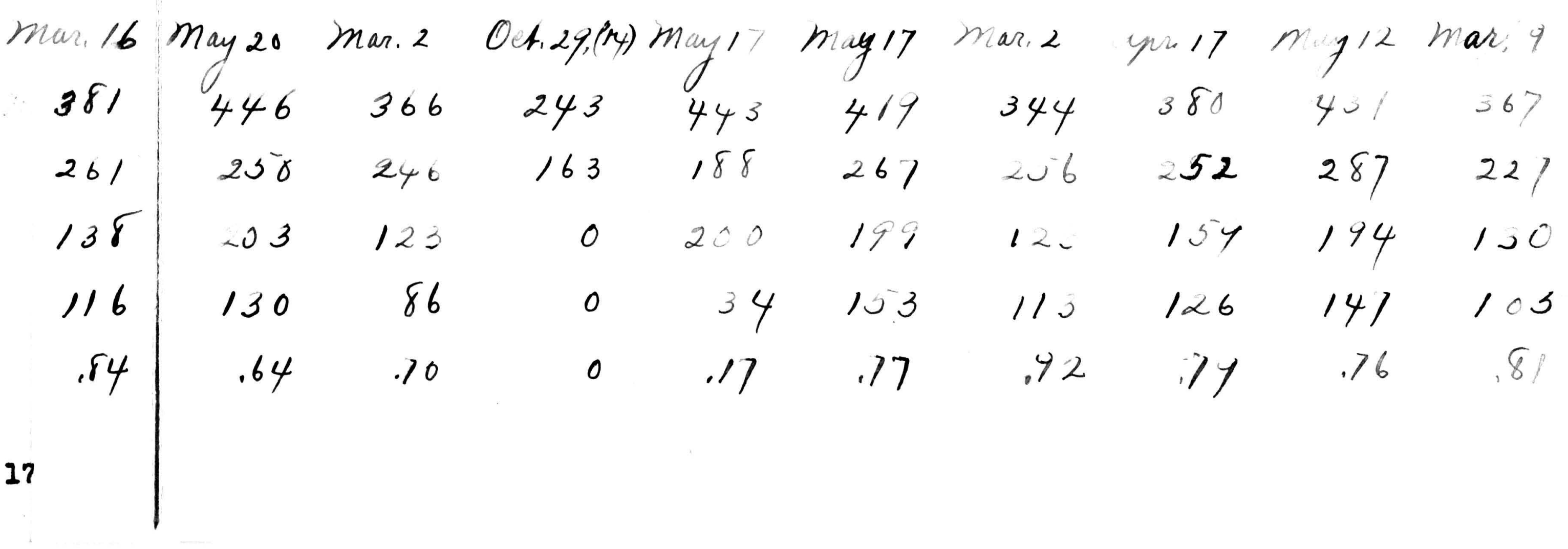

$167 \quad 185 \quad 178 \quad 176$

maví́ mar.13 ma.1, mar. 10

$381 \quad 378 \quad 363 \quad 373$

$260 \quad 274 \quad 270 \quad 272$

$255^{4} 246^{5} \quad 247^{2}$

$10 \quad 3 \quad 1$

18.36

$5.70 \quad 7.75$

2

250

$18 \quad 208 \quad 163$

up. 1s mar,s

$378 \quad 363$

$273^{2} \quad 262$

$253^{5} \quad 242$

6

14,65

4

$4.6^{3}$

65

11.4

6

${ }^{4}$ Four days after ${ }^{5}$ Delivery not complete. See page 17

${ }^{6}$ Seven davs after 
four or fire times a day, and she was allowed some blue grass to hasten her recovery.

April 37th a ten-day digesti on trial was started with Nos, 5, 9, and 6 (No. 5 suckling six plge, No. 9 having produced a I1tter, No. 6 open).

It was thought best to walt a few days after the close of the digestion trial, May 7th, before slaughtering for analy818. Each animal that had produced plgo was to be slaughtered the same number of days after farrowing--the date for slaughter was as fol10rr: No. 9, May 12; Nos, 5 and 6, May 17; and No. 2, May 20.

It should be noted here that May 21, No. 5 went slightly off feed. She not plolently 111, but she soemed to ouffer more than the others from the heat; she appeared to be somewhat rheumatio, a little lame, slow in her morements, and a little uncertain on her foet. Her general appearance reminded the writer of some low ash diet calves, and the analyis of this animal for ash 18 awaited with much interest.

No. 2 was the last of the ten gilts with which the Investigation was begun, thus her slaughter closed the experiment with the ilve animale.

In order to facliltate a study of the ohronology of the experiment the following table, No. 1a, 1s introduced in recapitulation. 


\section{$18 b$}

In the following pages wo hall attempt to describe, in onough detall to give an understanding of the conditiono, ouch phases of the rork as appear to neod any further explanat1on; present enough of the original data to enable the reader to make his own study and dram his own conclusions; and make some comparisons and give some disouselon of the results. 


\section{Weights}

vinot (4) considers weight the best single measure of the growth of an organism. It may be a measure of the increase in fatness as well. These weighings were made under as nearly uniform conditions as was possible with the conditions undet which the work was done. Variations in weight were to be expected. When the pens were muddy each animal might carry more or less mud when she was welghed. Then it was rainy water was carried in the hair. The weight was affected, by whether urination or defacation had occurred just before the animal was driven on the scales. The variation in the weight of a gilt from day to day was frequently three to five pounds, sometimes running as high as six or seven pounds for no apparent reason. Therefore a small variation where only one day's weight is taken cannot be considered significant. The accompanying table makes a comparison of the gains in weight of five pregnant gilts and two open gilts for each half of the gestation period, and for the entire period. The weights for the first half include the reights of the developing I1tters. In the comparisons for the second half and for the entire period, when the welght was known, the welght of litter and afterbirth was subtracted from the total gain because we are trying to find the effect upon the mother, not upon the Iitter. The subtraction of this welght, for the second half of the period introduces an error of whatever weight the young had attained in the first half of the period. There should be deducted only the amount that the young had increased in weight 
Table No. 2

Comparison of Gains in Pounds Live Weight of

Pregnant and Open Gilts.

All Welghts are three day Averages.

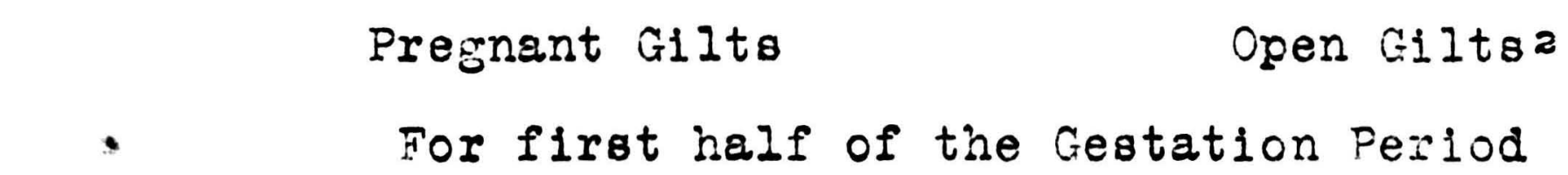

No. 1 No. 2 No. 3 No. 5 No. 9 , No. 6 No. 10

Vielght at Breeding $166.00 \quad 185.00 \quad 177.00 \quad 176.00 \quad 163.00 \quad 132.00 \quad 147.00$

$\begin{array}{llllll}\text { age et aradng,daje } 268 & 263 & 251 & 260 & 253\end{array}$

\begin{tabular}{|c|c|c|c|c|c|c|c|}
\hline $\begin{array}{l}\text { Welght } 57 \text { days } \\
\text { later }\end{array}$ & 206.00 & 238.00 & 216.00 & 220.00 & 210.00 & 178.00 & 186.00 \\
\hline Gain in Weight & 40.00 & 43.00 & 39.00 & 44.00 & 47.00 & 46.00 & 39.00 \\
\hline . Daily gain & 0.70 & 0.75 & 0.68 & 0.77 & 0.82 & 0.80 & 0.68 \\
\hline Av. Daily for & & & 0.75 & & & & .74 \\
\hline
\end{tabular}

For second half of the Gestation Period

Welght at Beginning 206.00 228.00 216.00 220.00 $210.00 \quad 178.00 \quad 186.00$

Welght at Farrowing $260.00 \quad 274.00 \quad 270.00 \quad 272.00 \quad 262.00 \quad 215.00 \quad 222.00$

Gains $\quad \begin{array}{lllllll}54.00 & 46.00 & 54.00 & 52.00 & 52.00 & 37.00 & 36.00\end{array}$

Weight Litter and

Afterbirth $23.00 * 8.00 \quad 10.00 \quad 17.00 \quad 13.00$

$\begin{array}{llllll}\text { Net Gains } \quad 31.00 & 36.00 & 44.00 & 35.00 & 39.00\end{array}$

No. days

$55 \quad 55 \quad 57$

$57 \quad 56$

57

57

Av. Daily Gain

$0.56 \quad 0.67$

0.77

0.61

0.70

0.65

0.63

Av. Daily for Group

0.66

0.64

For Entire Gestation Period

Total Net Gein

$71.00 \quad 81.00$

83.00

79.00

86.00

83.00

75.00

No. Days

$112 \quad 112$

114

112

113

114

114

Av. Da1ly Gain

$0.63 \quad 0.72$

0.73

0.70

0.76

0.73

0.66

Av. Da1ly for Group

0.71

0.70

*This weight is too high to be comparable with the others because It includes the amniotic fluld

a For this comparison the first weights of the open gilts were taken November 15--about the middle of the breeding period. 
thru this period. This error is probably not very great and is somewhat offet by the fact that the weight subtracted does not, except in the case of gilt No. 1, include the weight of the amnlotic fluld, which probably is fuliy as great as the weight attained by the young in the first half of the period.

A comparison for this second period using the gross weight of the pregnant gilts before farrowing shows an average of 0.28 pounds dally gain in favor of the pregnant gilts. Th1s amounts in 57 days to 15.96 pounds. This is 1.76 pounds greater than the average of the amount sutracted as the welght of litter and afterbirth. It should be remembered, however, that the weight subtracted 18, except in the one instance, less than the weight expelled at parturition because the weight of the amniotic fluid could not be ascertained. It may aloo be remarked here that the welght of the mother inciudes the temporarily increased welght of the reproductive organs, which the slaughter house data indicates is from 2 to 3 pounde. To be sure, this increased welght is a part of the mother organism aleo

as is the increased mammary, but it seems questionable whether this temporary increase should be considered growth.

The average dally gains for the two groups in all three of the comparisons show very Iittie difference, 0.01 pounds for the firot half and for the whole period, and 0.02 pounds for the second haif of the gestation period. An examination of the average daily gains of each animal shows in the first half of the period the highest gain by a pregnant gilt, and the second highest by an open gilt, the other open gilt tying 
with another pregnant one for low place. For the second half of the perlod the three highest gains are by pregnant gilts, but the two lowest places are also held by pregnant animals. For the whole period the first place is taken by a pregnant gilt; one pregnant and one open tying for second place, with a pregnant one last.

From this comparison of weights then we can not conclude that there is any difference in the pregnant and open animals, the difference between groups in each case being less than the differences within the groups.

It may be significant that the gilt, No. I, showing the least gain for the second half and for the entire period Is the pregnant gilt that produced the largest litter.

\section{Ration}

Thru the gestation period each animal received the same amount of feed dally, $1 . e .$, the feed for all gilts was increased the same amount at the same time. The different times of breeding, however, resulted in a olight var1ation in the total amount consumed. For example, Gilt No. 3 was bred November 6 th and farrowed Harch 1st, while Gilt No. 1 was not bred t1ll November 23 rd and was slaughtered líarch 16th, presumably one day before farrowing. No. I recelved a little more feed per day after the slaughter of No. 3 than No. 3 received before the breeding of No. 1 .

November 15th, about the middle of the breeding period, was chosen as the beginning date for the open gilts to compare both gains in welght and welght of feed consumed. The variations in the amount of feed consumed seem not large 
enough to make an appreciable difference in the results. Table No. 3 shows the amount consumed by each gilt for the different months. The average for the five pregnant gilts is for the feriod.

2.1 pounds less, than the amount consumed by each open gilt.

We cannot present a complete analysis of all the

feed used in this experiment as the analytical work is not yet completed. Since the same kind of feed was used thruout the experiment a comparison of the amounts consumed will introduce no appreciable error in the results of this one experiment.

In a discussion of the gains in welght during pregnancy it was observed that the smallest average dally gain was made by the gilt producing the largest litter. In this table of feed consumed it is shown that she consumed the greatest amount of feed. The excess is not great, only 3.9 pound for the period more than was consumed by the open gilts, but this makes us sure that her smaller gain was not due to a smaller amount of feed.

\section{Measurements}

That opportunity may be afforded for study of the individual animals and comparison of their growth from time to time, a complete record of the measurements is presented no.'s 4 to/2.
in the following tables, 1 These tables show the growth of the animalo and also serve to indicate the degree of accuracy with which it is possible to make such measurements. 
Table No. 3

Weight of Feed consuried in Pounds

during Preginancy

Pregnent Gilts

Open Gilts for

114 days,

Beginning irov. 15

No. 1 No. 2 No. 3 No. 5 No. 9 iNo. 6 No. 10

Date of

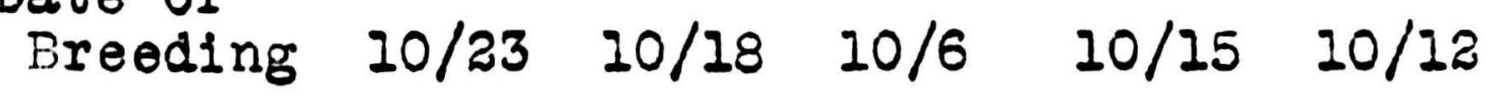

$\begin{array}{llllllll}\text { November } \quad 32.2 & 54.1 & 100.3 & 66.1 & 78.1 & 66.1 & 66.1\end{array}$

$\begin{array}{llllllll}\text { December } & 142.8 & 142.8 & 142.8 & 142.8 & 142.8 & 142.8 & 142.8\end{array}$

$\begin{array}{llllllll}\text { January } & 148.8 & 148.8 & 148.8 & 148.8 & 148.8 & 148.8 & 148.8\end{array}$

$\begin{array}{llllllll}\text { February } & 147.9 & 147.9 & 147.9 & 147.9 & 147.9 & 147.9 & 147.9\end{array}$

$\begin{array}{llllllll}\text { Narch } & 81.0 & 54.0 & 5.4 & 37.8 & 27.0 & 43.2 & 43.2\end{array}$

$\begin{array}{llllllll}\text { Total } & 552.7 & 547.6 & 545.2 & 543.4 & 544.6 & 548.8 & 548.8\end{array}$ 
Table 4

Measurements of Gilt No. I in centimeters.

Date of Birth, Narch 1, 1914.

Date

Weight, Pounds

Hieight at Withers

Helght at Croup

Width of Shoulders

Width of Shoulder Points

Width of Hams

Width of Ham Points

Width of Head

Heart G1rth

Paunch Girth

Flank Girth

Length of Body

Depth of Chest

Clrcumference of Cannon, front

C1rcumference of Cannon, rear

Distance from Elbow to Ground 26.0

Distance from Shoulder

Point to Ground

100.0

90.0

82.0

29.0

14.0

28.0

$$
10 / 18 / 14
$$

$$
140.0
$$

51.0

59.0

26.0

21.0

24.0

19.0

15.0

95.0

15.0

15.0

15.0

16.0

$14.5 \quad 15.0$

29.0

15.5

15.5

16.5

29.5

29.0

28.0
30.0

31.0

30.0

31.0 


\section{Table 5}

Measurements of Gilt No. 2 , in centimeters

Date of Birth, Larch 1, 1914.

Date $10 / 18 / 1411 / 21 / 14$

We1ght, Pounds 168.0

Helght at Withers 52.0

Helght at Croup 61.0

Width of Shoulders

29.0

31.0

$23.0 \quad 23.0$

26.0

21.0

15.5

96.0

Heart Girth

Paunch Girth

Flank Girth

Length of Body

Depth of Chest

Circumference of Cannon, front

Circumference of Cannon, rear

Distance from EIbow to Ground

Distance from

Shoulder Point to Ground

186.0

53.0

63.0

28.0

22.0

16.0

102.0

108.0

99.0

$82.0 \quad 88.0$

30.0

31.0

15.0

15.5

15.5

16.0

27.0

28.0

30.0

30.0
29.0

28.0

28.0

28.0

28.0

31.0

$30.0 \quad 30.0$

30.0

30.0 


$$
\begin{gathered}
\text { Table } 6 \\
\text { Measurements of Gilt No. 3, in centimeters } \\
\text { Date of Birth, March 1, } 1914 .
\end{gathered}
$$

Gilt No. 4

\begin{tabular}{|c|c|c|c|c|c|c|}
\hline Date & $0 / 18 / 14$ & $11 / 21 / 14$ & $12 / 31 / 14$ & $2 / 4 / 152$ & $2 / 28 / 15$ & $10 / 28 / 14$ \\
\hline Weight, Pounds & 165.0 & 186.0 & 217.0 & 245.0 & 271.0 & 254.0 \\
\hline Height at Withers & B 54.0 & 55.0 & 59.0 & 60.0 & 58.0 & 53.0 \\
\hline Helght at Croup & 64.0 & 64.0 & 66.0 & 68.0 & 67.0 & 59.0 \\
\hline $\begin{array}{l}\text { Width of Shoul- } \\
\text { ders }\end{array}$ & 30.0 & 30.0 & 30.0 & 33.0 & 35.0 & 28.0 \\
\hline $\begin{array}{l}\text { Width of Shoul- } \\
\text { der Points }\end{array}$ & 23.0 & 23.0 & 24.0 & 25.0 & 38.0 & 23.0 \\
\hline Width of Hams & 26.0 & 27.0 & 29.0 & 29.0 & 32.0 & 26.0 \\
\hline $\begin{array}{l}\text { Width of Ham } \\
\text { Points }\end{array}$ & 21.0 & 22.0 & 24.0 & 24.0 & 24.0 & 20.0 \\
\hline Width of Head & 15.0 & 15.0 & 16.5 & 16.0 & 17.5 & 15.0 \\
\hline Heart Girth & 98.0 & 105.0 & 110.0 & 119.0 & 121.0 & 95.0 \\
\hline Paunch Girth & 110.0 & 121.0 & 123.0 & 135.0 & 141.0 & 104.0 \\
\hline Flank Girth & 94.0 & 104.0 & 109.0 & 120.0 & 124.0 & 94.0 \\
\hline Length of Body & 82.0 & 89.0 & 90.0 & 96.0 & 97.0 & 82.0 \\
\hline Depth of Chest & 31.0 & 32.0 & 34.0 & 35.0 & 36.0 & 31.0 \\
\hline $\begin{array}{l}\text { Circumference of } \\
\text { Cannon, front }\end{array}$ & 14.5 & 15.0 & 15.5 & 15.0 & 15.5 & 15.5 \\
\hline $\begin{array}{l}\text { C1roumference of } \\
\text { Cannon, rear }\end{array}$ & 15.0 & 15.3 & 15.5 & 15.2 & 15.2 & 15.5 \\
\hline $\begin{array}{l}\text { Distance from El- } \\
\text { bow to Ground }\end{array}$ & -27.0 & 28.0 & 28.5 & 28.0 & 29.0 & 26.0 \\
\hline $\begin{array}{c}\text { Distance from } \\
\text { Shoulder Point } \\
\text { to Ground }\end{array}$ & 29.5 & 30.5 & 31.0 & 29.0 & 32.0 & 29.0 \\
\hline
\end{tabular}

Date of Birth, March 1, 2914 


\title{
Table no. 7
}

\begin{abstract}
Measurements of Gilt No. 5, in centimeters.
Date of Birth, March I, 1914.
\end{abstract}

Date $10 / 18 / 14 \quad 11 / 21 / 14$

$1 / 1 / 15$

$2 / 4 / 25$

$2 / 28 / 15$

$4 / 10 / 155 / 11 / 15$

Weight, Pounds 160.0 180.0 207.0 240.0 265.0 203.0 194.0

Height at Withers 54.0 55.0 $57.0 \quad 59.0$

62.0 57.0 57.0

Hetight at Croup

62.0 60.0 $64.0 \quad 64.0$ 67.0 68.0 66.0

Width of Shoulders

29.0

28.0

$29.0 \quad 33.0$

35.0

30.0

30.0

Width of Shoulder Points 21.0 24.0 24.5 24.0 27.0 $24.0 \quad 26.0$

Width of Hams 27.0 $28.0 \quad 28.0$ 31.0 32.0 $29.0 \quad 28.0$

Width of Ham Points

21.0

21.0

$22.0 \quad 24.0$

25.0

21.0

21.0

Width of Head

16.0

15.5

$17.5 \quad 17.5$

17.5

17.0

17.0

Heart Girth

95.0

98.0

$109.0 \quad 114.0$

126.0

$105.0 \quad 103.0$

Paunch Girth

105.0

116.0

120.0

129.0

140.0

119.0

118.0

Flank Girth

95.0

100.0

107.0118 .0

125.0

$109,0 \quad 107.0$

Length of Body

85.0

88.0

90.0

96.0

95.0

96.0

93.0

Depth of Chest

31.0

31.0

$34.0 \quad 34.0$

38.0

34.0

34.0

Circumference of Cannon, front

15.0

15.0

$16.0 \quad 15.0$

15.5

16.0

16.0

Circumference of

Cannon, rear

15.0

15.8

16.0

16.0

16.0

16.0

15.5

Distance from elbow to Ground

27.0

27.0

28.0

28.5

29.0

31.0

29.5

Distance from Shoulder Point to Ground 
Taple no. 8

Measurements of Gilt No. 6 , in centimefers.

Date of B1rth, March 24, 1914.

Date

$10 / 18 / 1411 / 21 / 14$

$1 / 1 / 15$

$2 / 4 / 15$

$2 / 28 / 15$

$4 / 10 / 155 / 11 / 15$

Welght, Pounds 120.0 139.0 $160.0 \quad 194.0$ 213.0 243.0 260.0

Height at Withers 50.0 $\begin{array}{llll}51.0 & 54.0 & 54.0 & 57.0\end{array}$

61.0

64.0

Helght at Croup 57.0

57.0

$61.0 \quad 60.0$

64.0

68.0

70.0

Width of Shoulders 26.0

26.0

$28.0 \quad 30.0$

32.0

33.0

37.0

Width of Shoulder

Point 8

20.0

21.0

24.0

22.5

25.0

26.0

27.0

jidth of Hams

24.0

26.0

$27.0 \quad 30.0$

31.0

32.0

33.0

Width of Ham

Points

18.0

20.0

$21.5 \quad 21.0$

22.0

24.0

25.0

Width of Head

14.0

14.0

$16.5 \quad 15.5$

17.0

18.0

18.0

Heart Girth

88.0

92.0

$97.0 \quad 106.0$

111.0

118.0

120.0

Paunch G1rth

100.0

104.0

$107.0 \quad 113.0$

122.0

125.0

125.0

Flank Girth

91.0

94.0

$102.0 \quad 105.0$

110.0

127.0

115.0

Length of Body

76.0

79.0

$81.0 \quad 91.0$

93.0

$98: 0$

99.0

Depth of Chest

29.0

29.0

$32.0 \quad 32.0$

33.0

36.0

38.0

Circumference of

Cannon, front

13.5

13.5

$14.0 \quad 14.5$

15.0

15.0

26.0

Circumference of Cannon, rear

13.5

14.0

$14.5 \quad 15.0$

15.5

16.0

16.5

Distance from elbow to Ground

25.0

26.0

$27.0 \quad 26.0$

26.0

29.0

30.0

Distance from Shoulder Point to Ground

27.0

28.0

$28.5 \quad 28.0$

28.0

31.0

33.0 


\section{Table no. 9}

Measurements of Gilt No. 7, in centimeters. Date of Birth, March 23, 1914.

\begin{tabular}{|c|c|c|c|c|c|}
\hline Date & $10 / 20 / 14$ & $11 / 21 / 14$ & $1 / 1 / 15$ & $2 / 4 / 15$ & $2 / 28 / 15$ \\
\hline Nelght, Pounds & 153.0 & 179.0 & 199.0 & 233.0 & 252.0 \\
\hline Neight at Withers & 52.0 & 53.0 & Too & 59.0 & 59.0 \\
\hline Height at Croup & 58.0 & 60.0 & Iame & 62.0 & 62.0 \\
\hline Vidth of Shoulders & 29.0 & 30.0 & to & 36.0 & 37.0 \\
\hline $\begin{array}{l}\text { idth of Shoulder } \\
\text { Points }\end{array}$ & 22.0 & 34.0 & measur & re. 26.0 & 28.0 \\
\hline With of Hams & 28.0 & 29.0 & Leg & 31.0 & 34.0 \\
\hline Math of Ham Points & 21.0 & 22.5 & broken. & 25.0 & 27.0 \\
\hline Widh of Head & 14.0 & 15.0 & & 17.0 & 17.0 \\
\hline Heart Girth & 97.0 & 104.0 & & 119.0 & 122.0 \\
\hline Paunch Girth & 113.0 & 119.0 & & 128.0 & 139.0 \\
\hline Flank Girth & 104.0 & 108.0 & & 110.0 & 120.0 \\
\hline Length of Body & 80.0 & 83.0 & & 90.0 & 92.0 \\
\hline Depth of Chest & 31.0 & 32.0 & & 36.0 & 36.0 \\
\hline $\begin{array}{l}\text { Circumference of } \\
\text { Cannon, front }\end{array}$ & 14.5 & 14.5 & & 16.0 & 16.0 \\
\hline $\begin{array}{l}\text { Circumference of } \\
\text { Cannon, rear }\end{array}$ & 13.5 & 14.5 & & 15.0 & 16.0 \\
\hline $\begin{array}{l}\text { Distance from EI- } \\
\text { bow to Ground }\end{array}$ & 27.0 & 28.0 & & 26.0 & 27.0 \\
\hline $\begin{array}{l}\text { Distance from Shoul- } \\
\text { der Point to Ground }\end{array}$ & $\bar{d} 29.0$ & 29.0 & & 29.0 & 30.0 \\
\hline
\end{tabular}


Table No. 10.

Measurements of Gilt No. 8, in centimeters.

Date of Birth, March 23, 1914.

Date

Weight, Pounds

Height at Withers

Height at Croup

Width of Shoulders

Width of Shoulder Points

Width of Hams

Width of Ham Points

Width of Head

Heart Girth

Paunch Girth

Flank Girth

Length of Body

Depth of Chest

Circumference of Cannon, front

Circumference of

Cannon, rear

Distance from EIbow to Ground

Distance from Shoulder Point to Ground
$10 / 20 / 1411 / 21 / 141 / 1 / 15$

$2 / 4 / 15$

$2 / 28 / 15$

$4 / 10 / 15$

133.0 151.0

$173.0 \quad 210.0$

232.0

272.0

48.0

$51.0 \quad 54.0 \quad 56.0$

61.0

60.0

56.0

57.0

61.0

62.0

65.0

66.0

26.0

27.0

28.0

31.0

32.0

34.0

21.0

22.0

24.0

23.0

26.0

26.0

25.0

27.0

27.5

30.0

31.0

33.0

18.0

20.0

22.0

23.0

23.0

26.0

13.0

14.0

16.0

15.5

17.0

17.5

89.0

89.0

98.0

107.0

115.0

120.0

98.0

105.0

109.0

118.0

127.0

140.0

94.0

92.

100.0

107.0

116.0

125.0

79.0

87.0

$89.0 \quad 93.0$

93.0

100.0

29.0

29.0

$32.5 \quad 33.0$

34.0

37.0

14.5

16.

14.0

15.0

15.5

15.0

13.5

15.0

14.0

14.5

16.0

16.0

26.0

26.0

27.0

28.0

26.0

29.0

28.0

28.0

29.0

30.0

29.0

31.0 


$$
\begin{gathered}
\text { Table No. } \\
\text { Measurements of Gilt No. 9, in centimeters. } \\
\text { Date of Birth, March 7, } 1914 .
\end{gathered}
$$

Date

$$
10 / 20 / 14
$$

$11 / 21 / 14$

148.0

172.0

54.0

62.0

60.0

Width of Shoulders 28.0

28.0

21.0

23.0

25.0

26.0

19.0

21.0

24.0

23.0

14.5

16.0

16.0

99.0

104.0

114.0

113.0

127.0

132.0

107.0

105.

113.0

87.0

88.0

91.0

31.0

34.0

34.0

24.0

16.5

123.0

140.0

127.0

95.0

35.0

24.0

17.5

119.0

134.0

122.0

98.0

38.0

38.0

Circumference of

Cannon, front

Circumference of

Cannon, rear

14.

14.0

15.5

14.5

14.5

15.5

15.0

15.5

Distance from $\mathrm{EI}$ bow to Ground

26.5

15.0

14.5

15.0

16.0

16.0

16.0

$$
28.0
$$

28.5

28.0

28.0

29.0

31.0

Distance from

Shoulder Posnt to Ground
29.
30.0

$31.5 \quad 30.0$

31.0

32.0

33.0 


$$
\text { Table nd. } 12 \text {. }
$$

Measurements of Gilt No. 10, in centimeters.

Date of Birth, March 7, 1914.

\begin{tabular}{|c|c|c|c|c|c|}
\hline Date & $10 / 20 / 14$ & $11 / 21 / 14$ & $1 / 1 / 15$ & $2 / 4 / 15$ & $2 / 28 / 15$ \\
\hline Weight, Pounds & 132.0 & 152.0 & 173.0 & 202.0 & 220.0 \\
\hline Helght at Withers & 50.0 & 53.0 & 54.0 & 57.0 & 59.0 \\
\hline Height at Croup & 58.0 & 60.0 & 61.0 & 64.0 & 65.0 \\
\hline Vidth of Shoulders & 27.0 & 28.0 & 28.0 & 31.0 & 33.0 \\
\hline $\begin{array}{l}\text { Fidth of Shoulder } \\
\text { Boints }\end{array}$ & 19.0 & 22.0 & 24.5 & 22.0 & 26.0 \\
\hline Midth of Hams & 24.0 & 26.0 & 27.5 & 30.0 & 31.0 \\
\hline Width of Ham Points & 19.0 & 21.0 & 22.0 & 23.0 & 23.0 \\
\hline Width of Head & 14.0 & 15.0 & 17.0 & 16.0 & 17.5 \\
\hline Eeart Girth & 87.0 & 94.0 & 98.0 & 103.0 & 110.0 \\
\hline Paunch Girth & 98.0 & 108.0 & 109.0 & 113.0 & 120.0 \\
\hline Flanks Girth & 87.0 & 97.0 & 100.0 & 103.0 & 107.0 \\
\hline Length of Body & 80.0 & 87.0 & 88.0 & 90.0 & 97.0 \\
\hline Depth of Chest & 28.0 & 29.0 & 32.0 & 32.0 & 33.0 \\
\hline $\begin{array}{l}\text { Circumference of } \\
\text { Cannon, front }\end{array}$ & 14.0 & 15.0 & 14.5 & 16.0 & 15.0 \\
\hline $\begin{array}{l}\text { Circumference of } \\
\text { Cannon, rear }\end{array}$ & 15.0 & 15.0 & 15.5 & 16.0 & 15.0 \\
\hline $\begin{array}{l}\text { Distance from EI- } \\
\text { bow to Ground }\end{array}$ & 25.0 & 27.0 & 27.5 & 28.0 & 26.0 \\
\hline $\begin{array}{l}\text { Diatance from Shor } \\
\text { der Point to } \\
\text { Ground }\end{array}$ & 27.0 & 29.0 & 31.0 & 29.0 & 29.0 \\
\hline
\end{tabular}


In table No. 13 is shown a comparison of the gains made by the different animals as determined by these measurements. These gains are from the first measurement October 18, 1914, to the last measurement before farrowing began, February 28, 1915. Th1s covers more time than the gestation period, but the differences from month to month are so small that this Is of little moment, since the time is the same for all the animals.

The averages for gain in height at both withers and croup are in favor of the open gilts, but a comparison of the gains by different individuals does not support the idea that the average represents the true situation. In gain in height at withers one of the pregnant gilts is highest, while two others are higher than one of the open gilts. That is to say that the average for three of the five pregnant gilts is higher than is the average for the two open gilts. In gain in height at croup two of the pregnant gilts have just exactly equalled the two open ones.

In length of body there appears to be a uniform gain in favor of the open ones. In width of head the gain appears to be slightly in favor of the open gilts. The above measurements most nearly indicate skeletal growth, except for the measurements of cannons which show very little alfference. While the average indicate that there is possibly greater growth made by the open animals than by the pregnant, a more careful study points out the fact that the greatest differences are individual differences rather than group differences. In the case of the length of body this is not so apparent, but even. 


\section{3 \\ Table 20.13}

Growth of Gilts as Shown by Measurements, in centimeters, from First Measurement to Close of Gestation Period,

Feb. 28, 1915.

\section{Height at Withers \\ Height at Croup \\ length of Body \\ Distance from elbow to ground \\ Distance from shoulder point to ground \\ Depth of Chest \\ Circumference of front Cannon \\ Circumference of rear Cannon \\ Width of Head \\ Width of Shoulder Points \\ Width of Shoulders \\ Width of Hams \\ Width of Ham Points \\ Heart Girth}

Gain in Weight, Pounds IOC
No.$$
8.0
$$

$7.0 \quad 4.0$

12.015 .0

4.0

3.0

15.0

8.0

7.0
4.0

No. $8^{*}$ No.9

10.0

12.0

6.010 .0

$5.0 \quad 7.0$

$11.0 \quad 14.0$

2.01 .0

2.0

2.0

0.0

2.0

1.5

1.0

$3.0 \quad 0.0$

3.0

2.0

5.0

7.0

5.0

2.0

2.0

4.5

5.0

$2.0 \quad 1.0$

1.5

$\begin{array}{lll}2.5 & 2.0 & 2.0\end{array}$

$2.0 \quad 1.0$

0.21 .0

$2.5 \quad 2.5$

$2.5 \quad 1.5$

3.0

$3.0 \quad 4.0$

6.07 .0

5.0

5.0

6.0

6.0

6.0

3.0

5.0

7.0

4.0

$106.098 .0 \quad 106.0 \quad 105.0$
$25.0 \quad 28.0 \quad 23.0 \quad 31.0$

Average for

five preg-

nant Gilts

\section{Average}

for

No.6 No.10 open Gilts

$\begin{array}{lrrr}\text { Height at Withers } & 7.0 & 9.0 & 8.0 \\ \text { Height at Croup } & 7.0 & 7.0 & 7.0 \\ \text { Length of Body } & 17.0 & 17.0 & 17.0 \\ \begin{array}{lrr}\text { Distance from elbow } \\ \quad \text { to ground }\end{array} & 1.0 & 1.0 & 1.0 \\ \begin{array}{l}\text { Distance from shoulder } \\ \text { point to ground }\end{array} & 1.0 & 2.0 & 1.5 \\ \begin{array}{l}\text { Depth of Chest } \\ \text { Circumference of front }\end{array} & 4.0 & 5.0 & 4.5 \\ \quad & & \\ \text { Cannon } & 1.5 & 1.0 & 1.3 \\ \quad \text { Cannon } & 2.0 & 0.0 & 1.0 \\ \text { Width of Head } & 3.0 & 3.5 & 3.3 \\ \text { Width of Shoulder } & & & \\ \quad \text { Points } & 5.0 & 7.0 & 6.0 \\ \text { Width of Shoulders } & 6.0 & 6.0 & 6.0 \\ \text { Width of Hams } & 7.0 & 7.0 & 7.0 \\ \text { Width of Ham Points } & 4.0 & 4.0 & 4.0 \\ \text { Heart Girth } & 23.0 & 23.0 & 23.0 \\ \text { Gain in Weight, Pounds } & 93.0 & 88.0 & 91.0\end{array}$

*No. 7. 88 days in pregnancy. No. 8, from Jan. I to Apr. 10. These two omitted from average. 
here the difference between the greatest gain by a pregnant gilt and the gain by an open one is only two centimeters, while a difference of five centimeters is shown between the gains of two of the pregnant gilts. Therefore we may conclude that these results indicate that the factor of individuality is strong enough to account for the differences observed.

$$
\begin{aligned}
& \text { Plctures } \\
& \text { pages } 37 t+40
\end{aligned}
$$
for himself something of how nearly uniform the animals were at the beginning of the experiment, and the change in appearance as the experiment progressed.

The first plctures were taken October 28, 1914, the second, February 25, 1915,--120 days later. Pictures were taken again May lath of all the gilts then alive. Each time a rear and ${ }_{1}^{a}$ side view were taken of each animal. The distance was always 320 centimeters. It was not always possible to get the animal to stand just exactly where it was desired and it was necessary to move the camera. Needless to say, we could not take a measurement for each changed position, but the distance was marked on the ground and care was observed to keep the same distance between the camera and the animal.

\section{Digestion Trials}

Each animal on digestion trial was confined in a crate where she could not turn around. Each crate is 5 feet long, 3 feet high, and 22 inches wide. Two iron rods back of the animal prevent it from backing from the crate and 


\section{7 \\ Gilt No. 7 .}

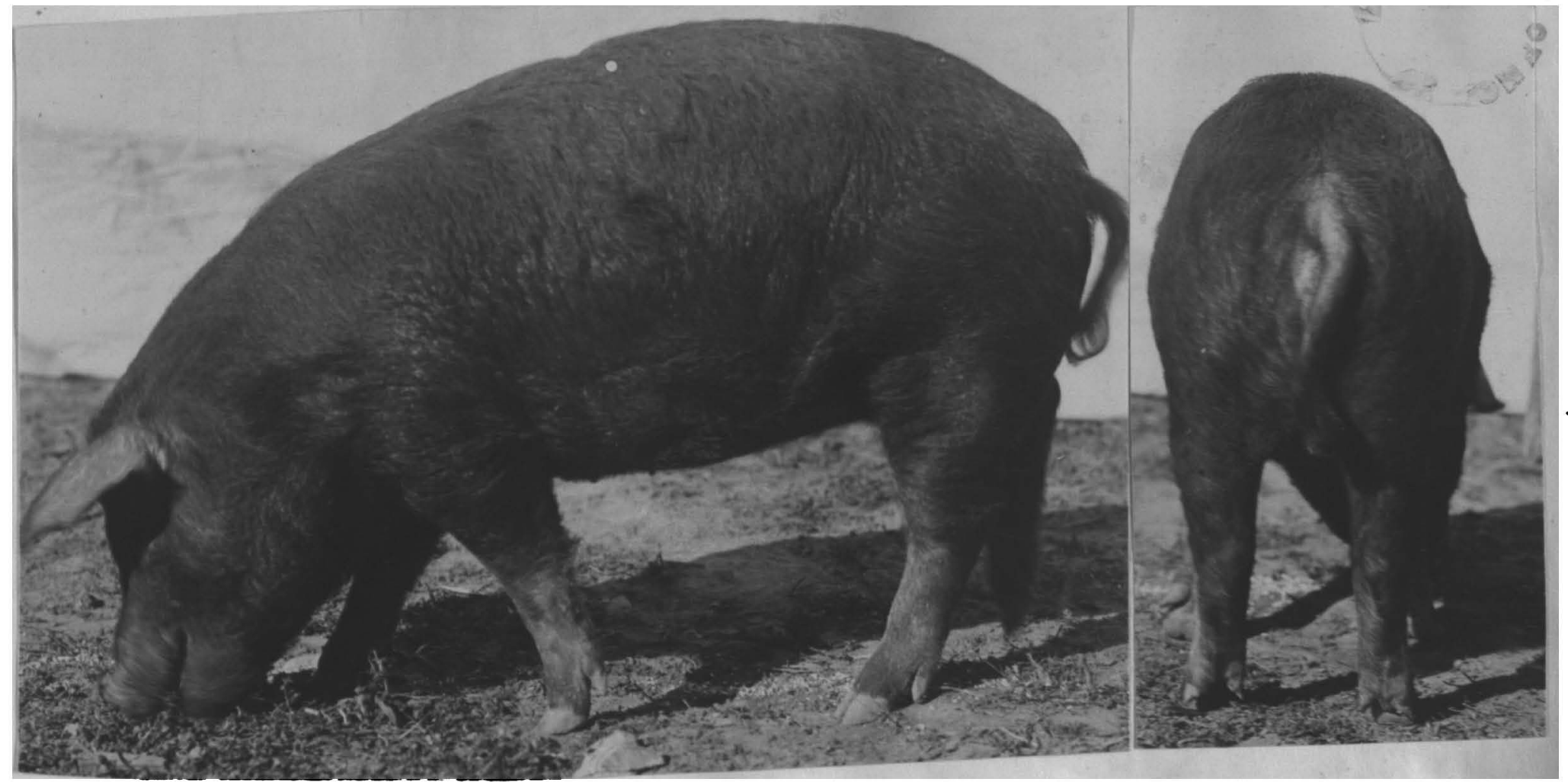

Oct. 29,1914-7mo.29days

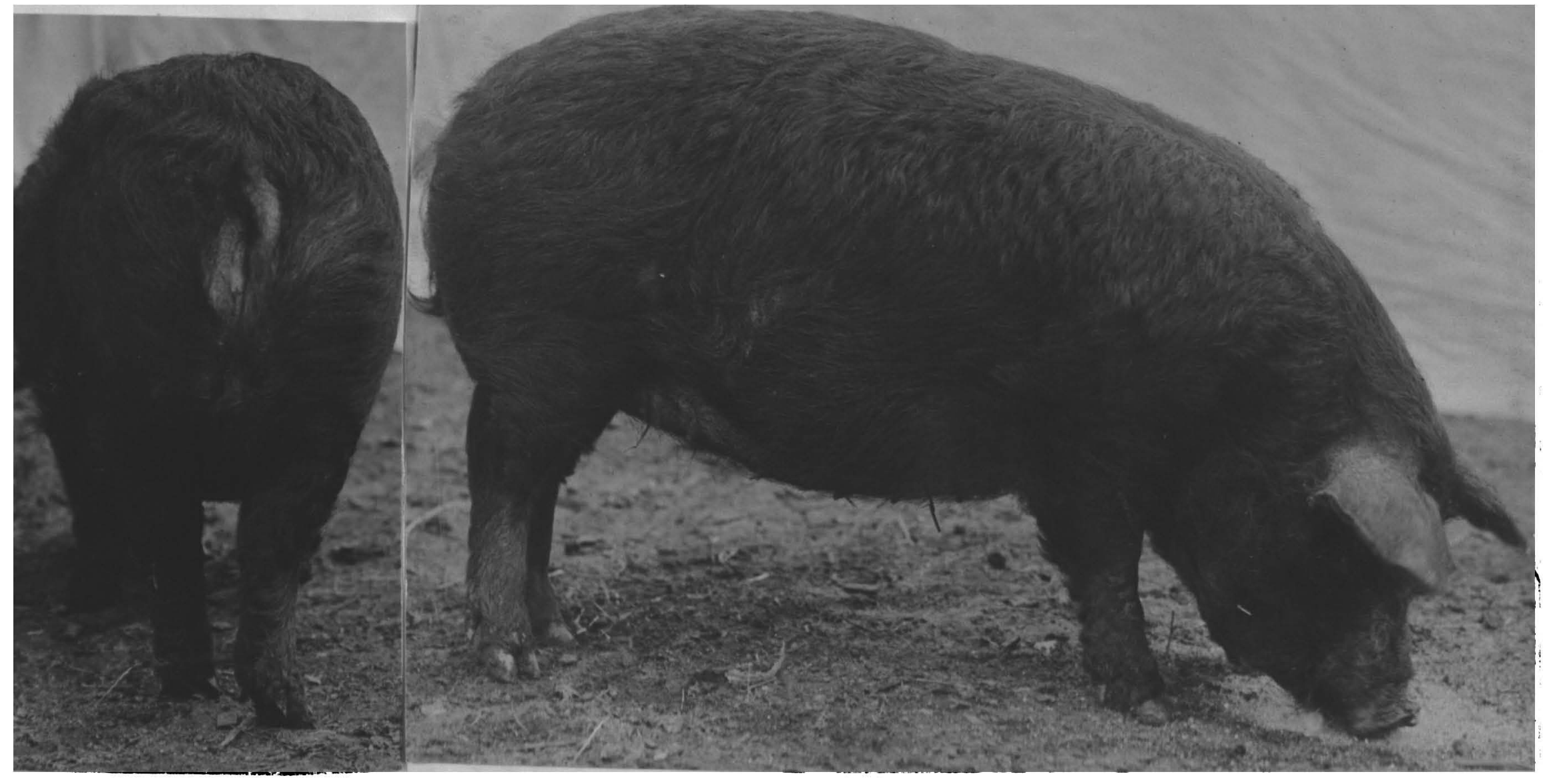

Feb. 25, 1916 - IImo.25days 


\section{$38^{\circ}$ \\ Gilt No.2.}

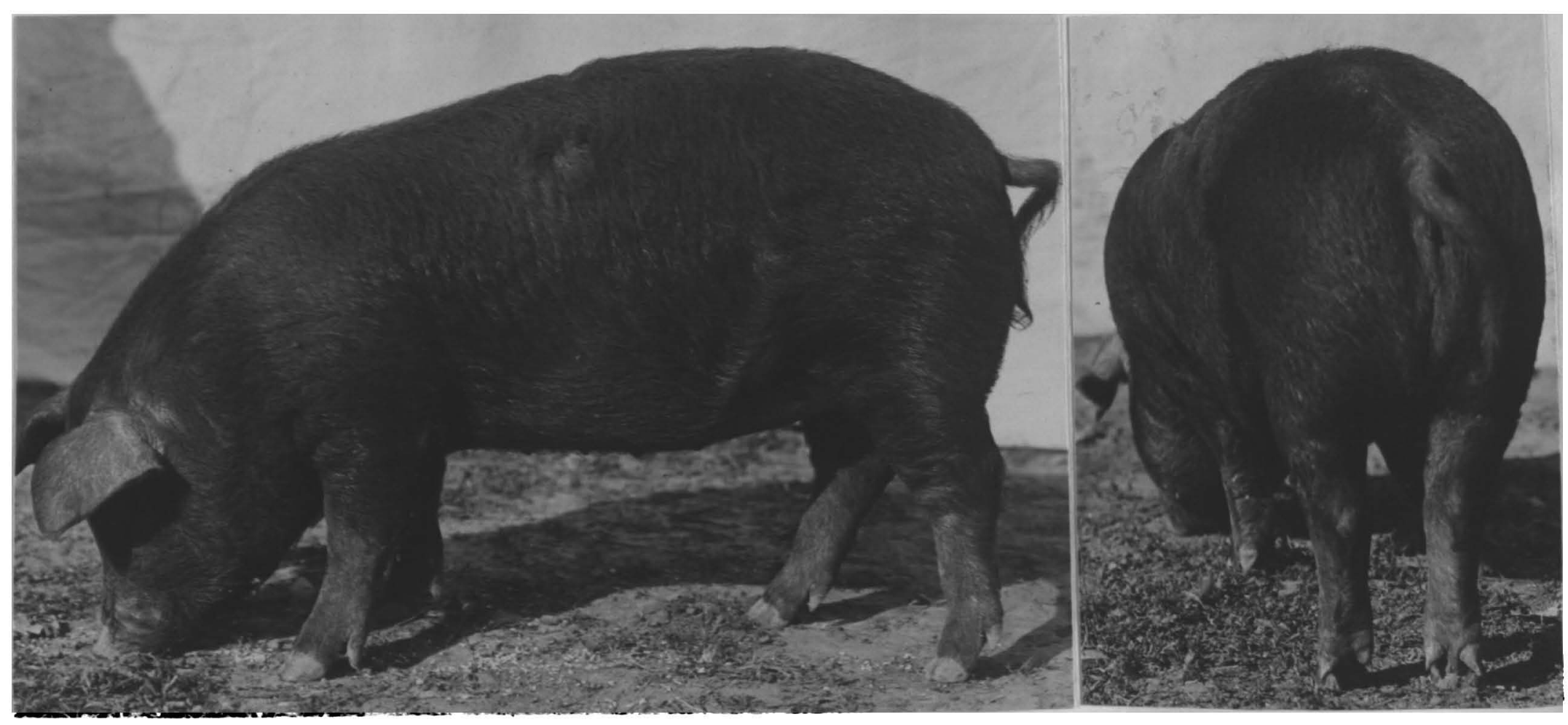

Oct.29,1914-7mo.29.days



Feb.25,1915- 'lmo.25days 


\section{4. \\ Gilt No.3.}



Oct.29.1914- 7 mo. 29days

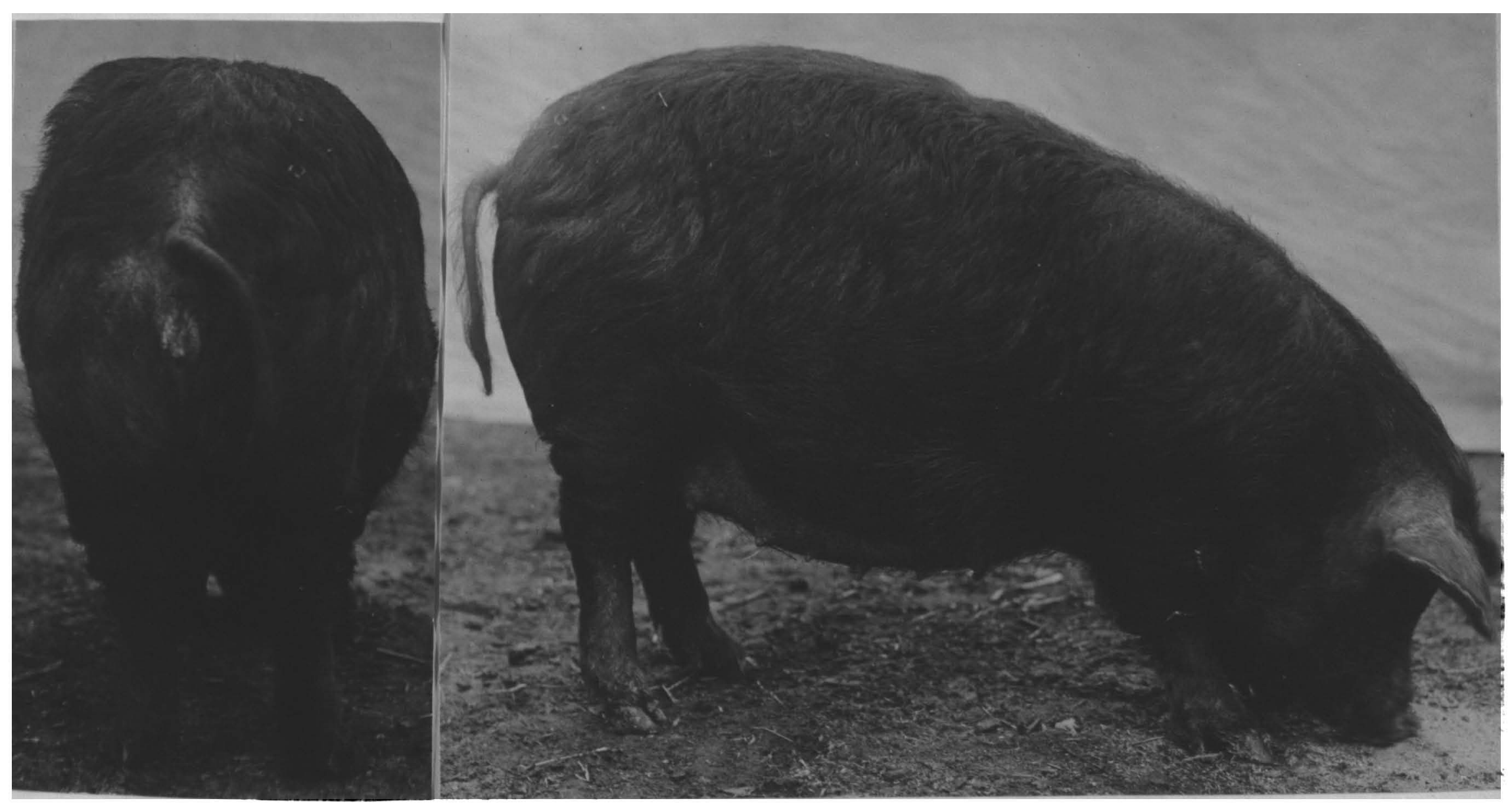

Feb.25,1915-11mo.25days 


$$
\begin{aligned}
& 40 \\
& \text { Gilt No. } 4 .
\end{aligned}
$$

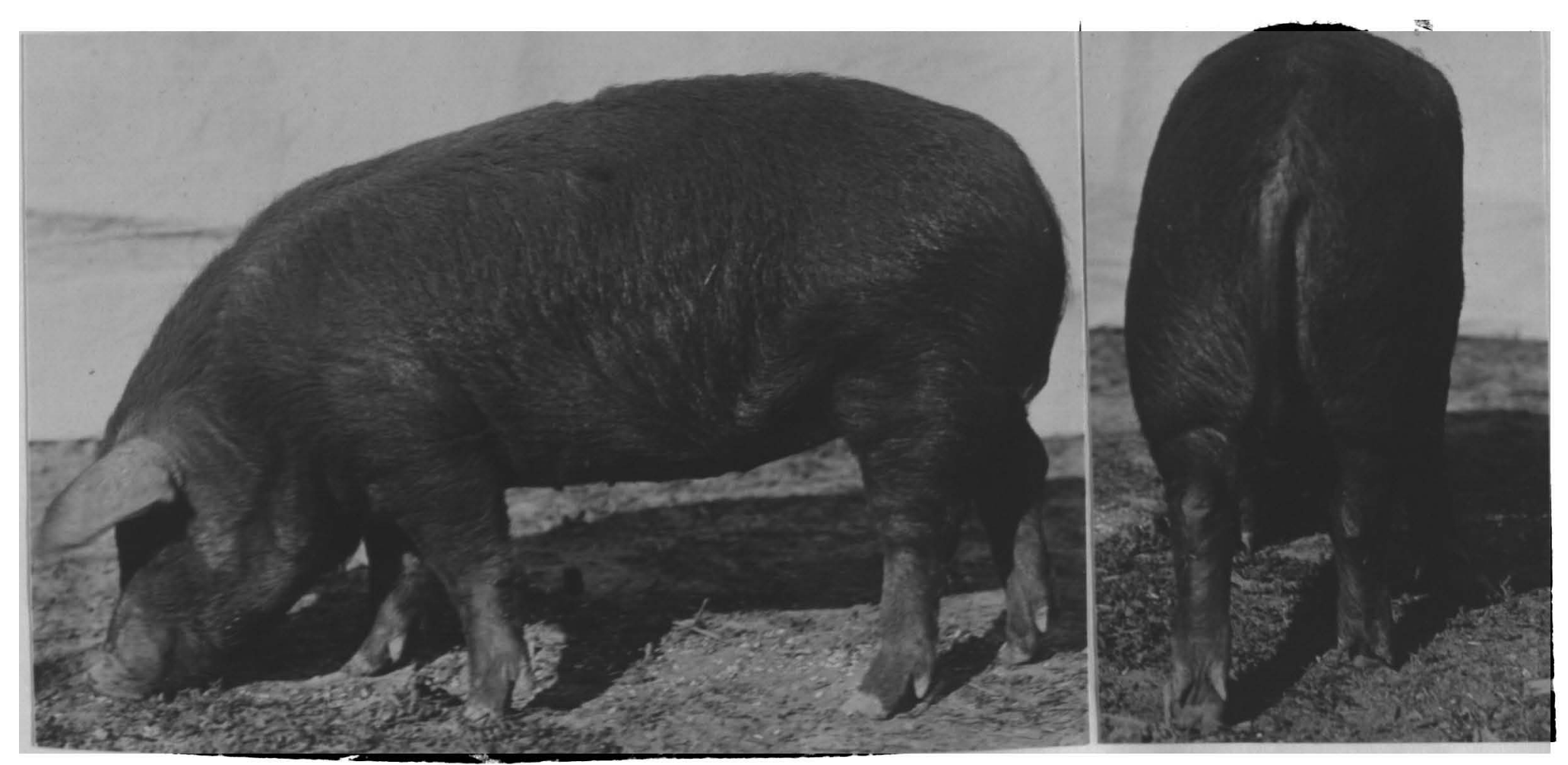

Oct.29,1914-7mo.29days 


\section{1}

\section{Gilt No.5.}



Oct.29.1914-7mo.29days

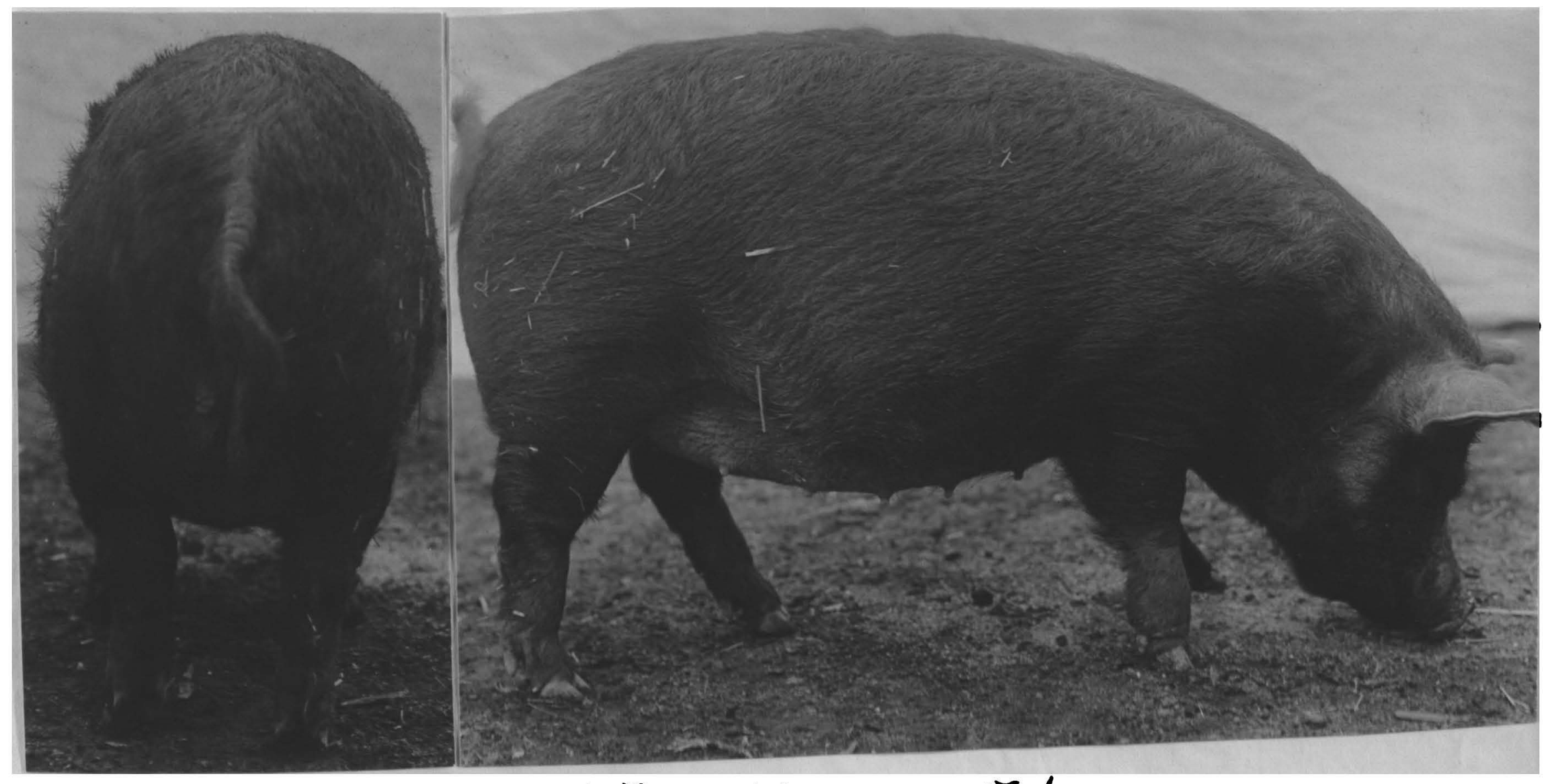

Feb.25,1915- IIm20.25days 
42

Gilt No. 6
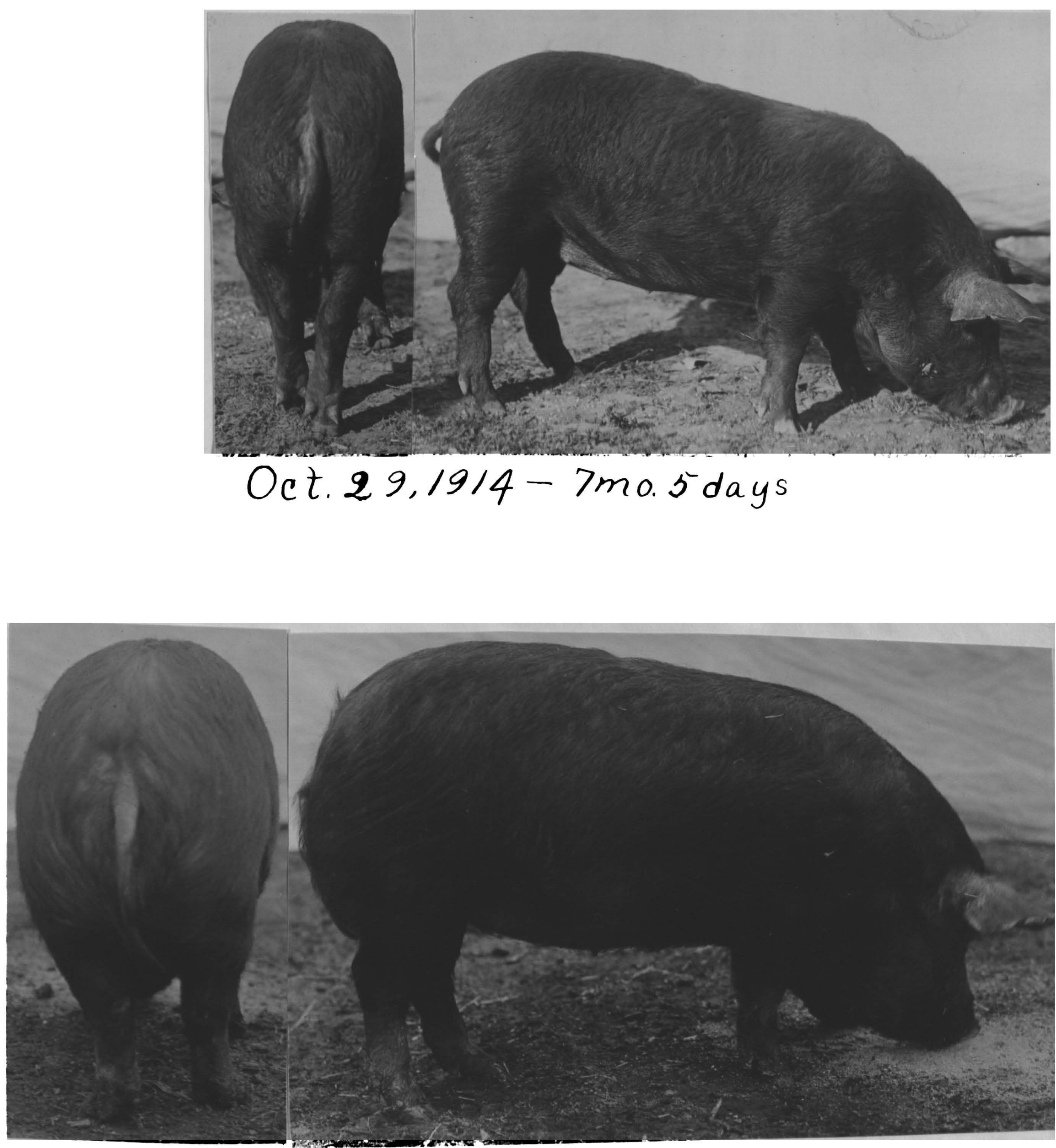

Feb.25,1915- IImo.lday 


\section{3}

Gilt No.9.

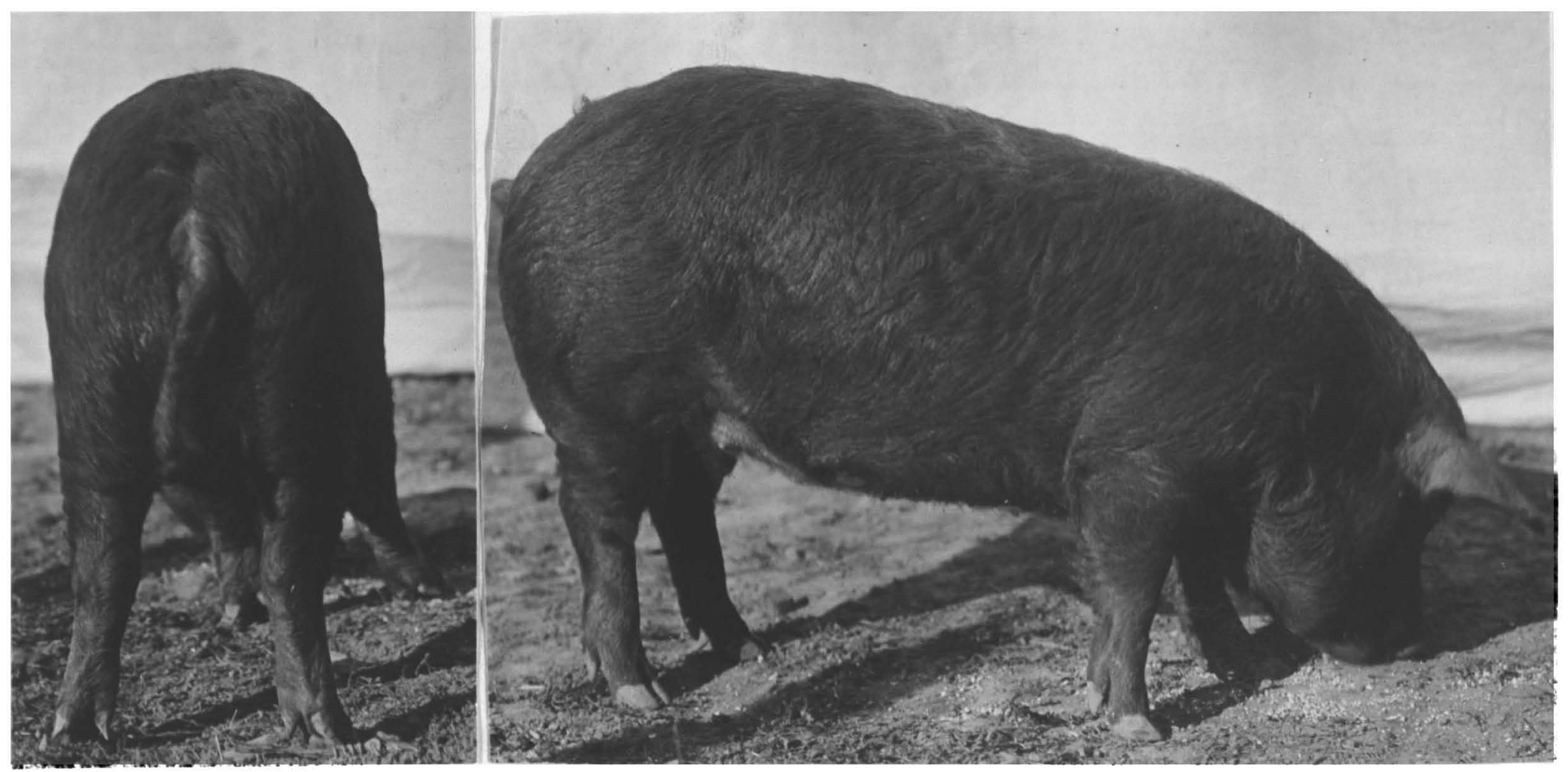

Oct.29,1914-7mo.22dans

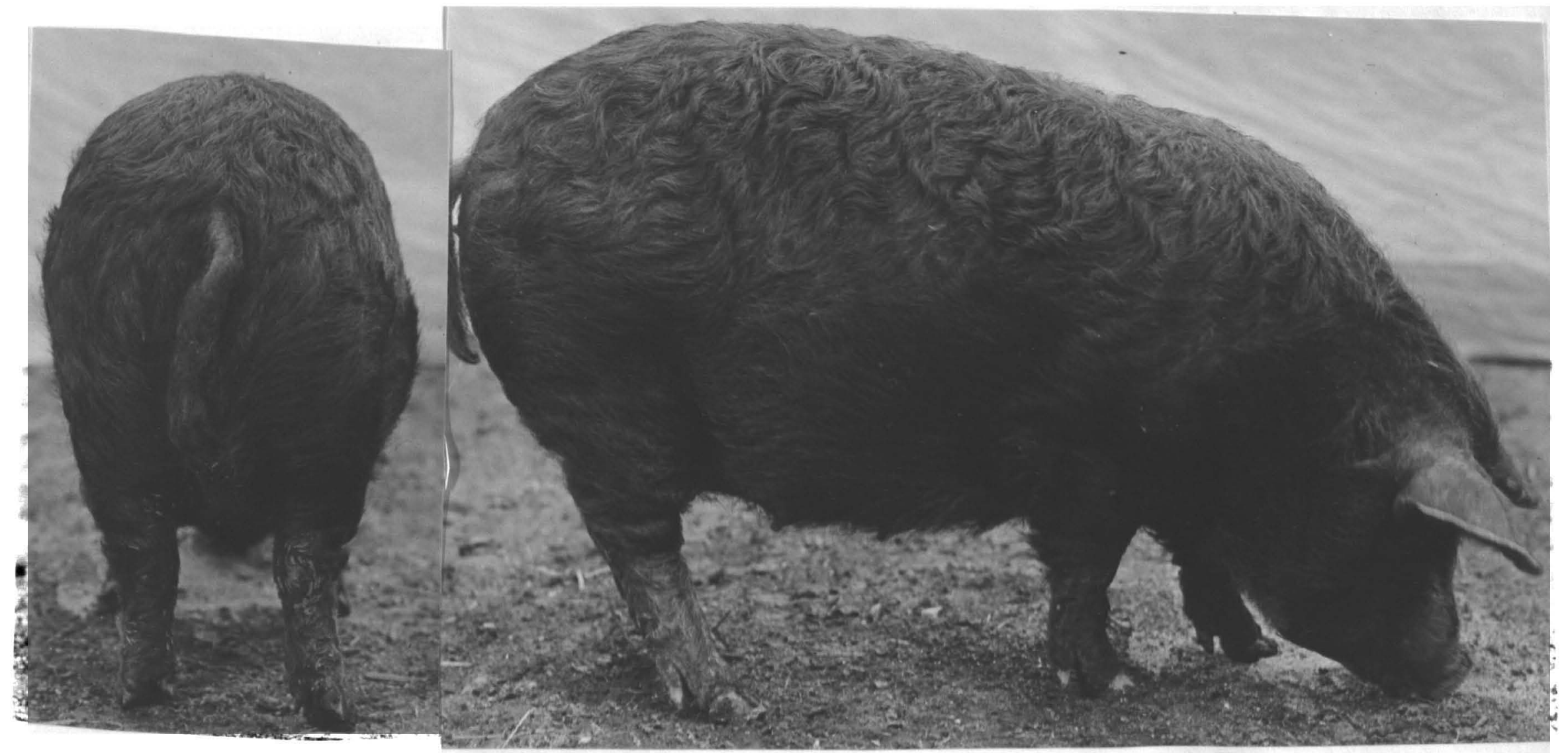

Feb.25,1915-11mo.18days 


\section{6}

Gilt No. 10.

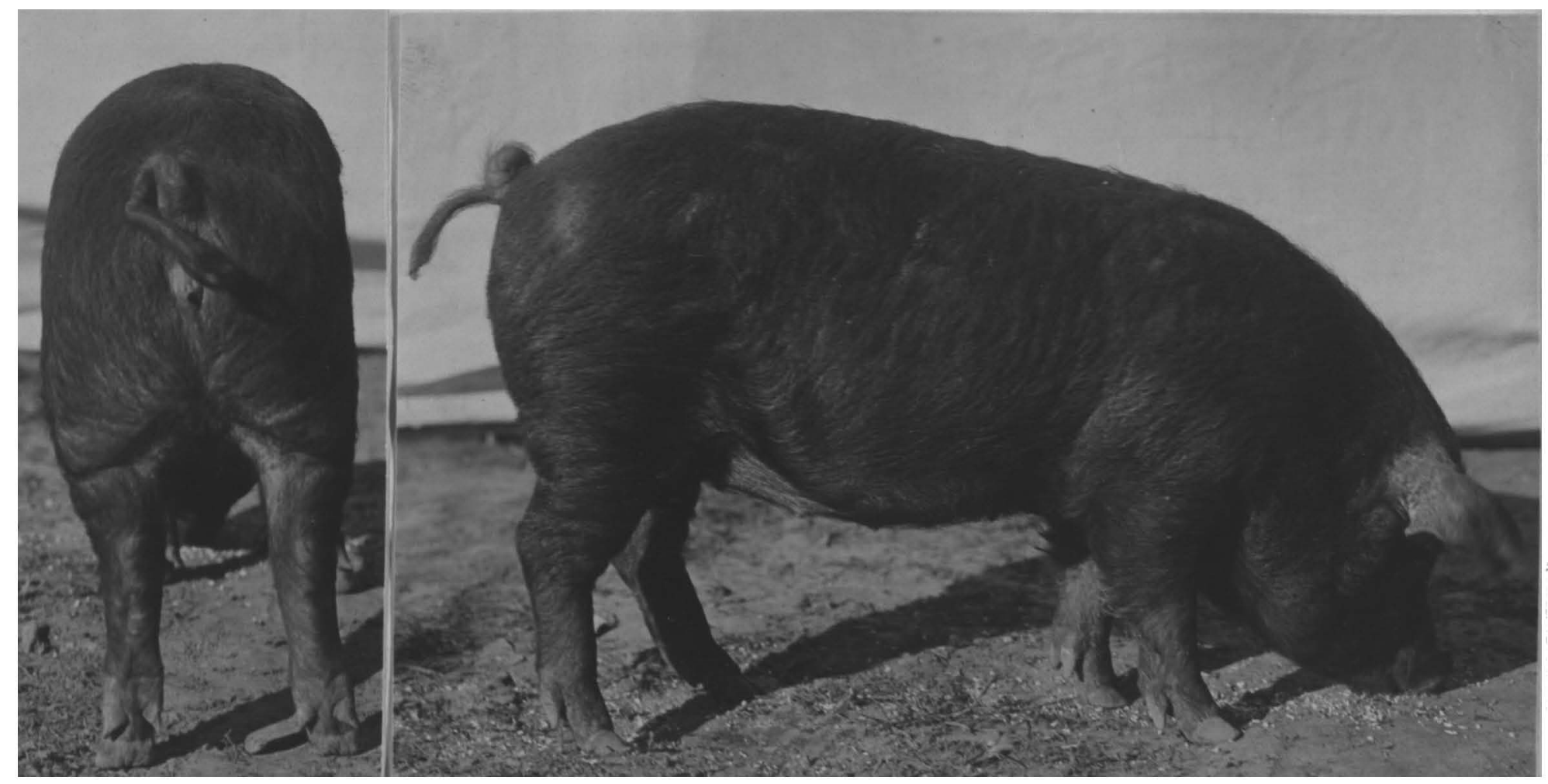

Oct.29,1914 - 7mo.22days

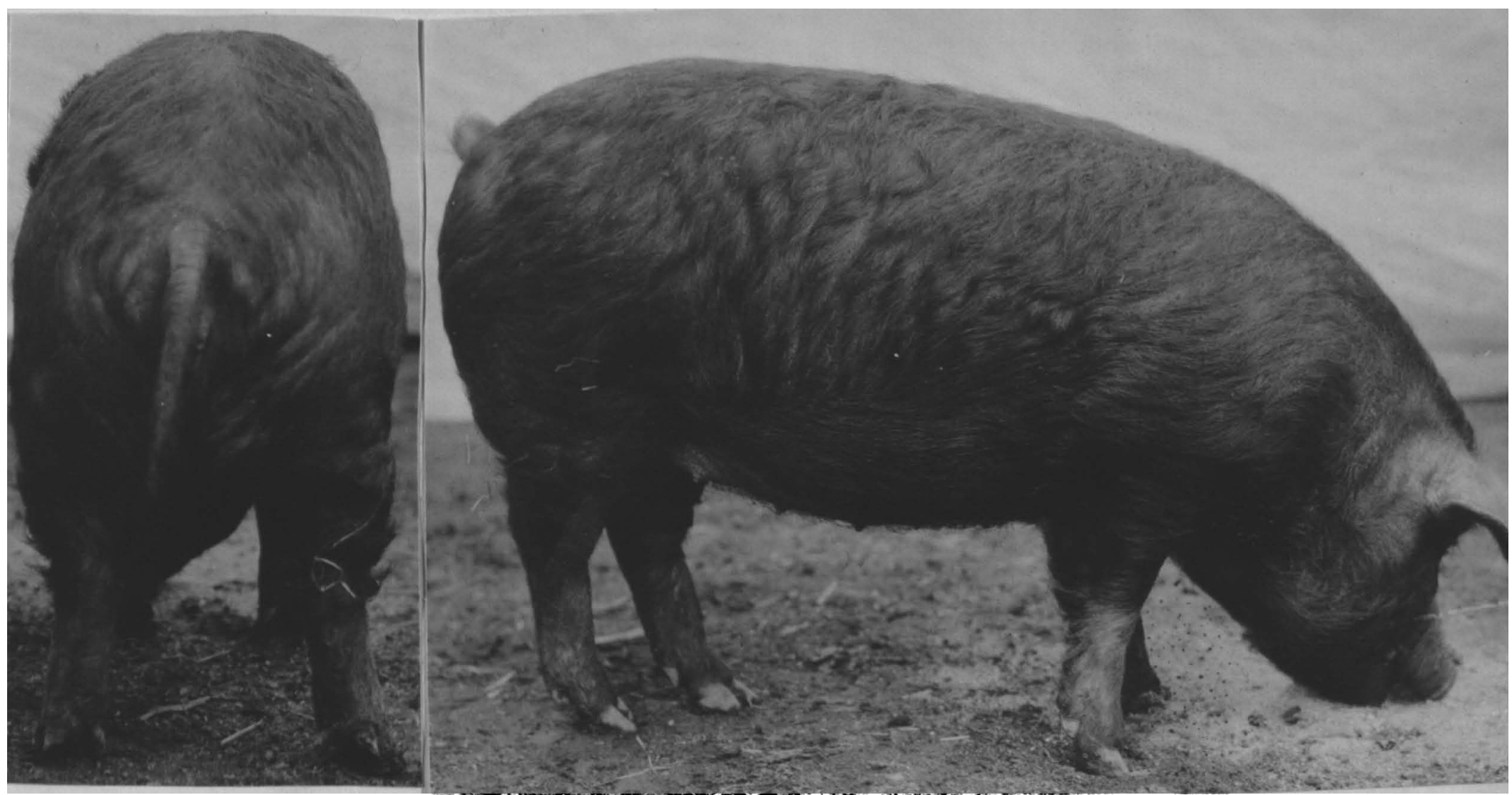

$\mathrm{Feb} 23,1915-11 \mathrm{mo}, 18$ days 


$$
=47
$$

Gilt No. 2 .

May 12,1915-14 mo.12days

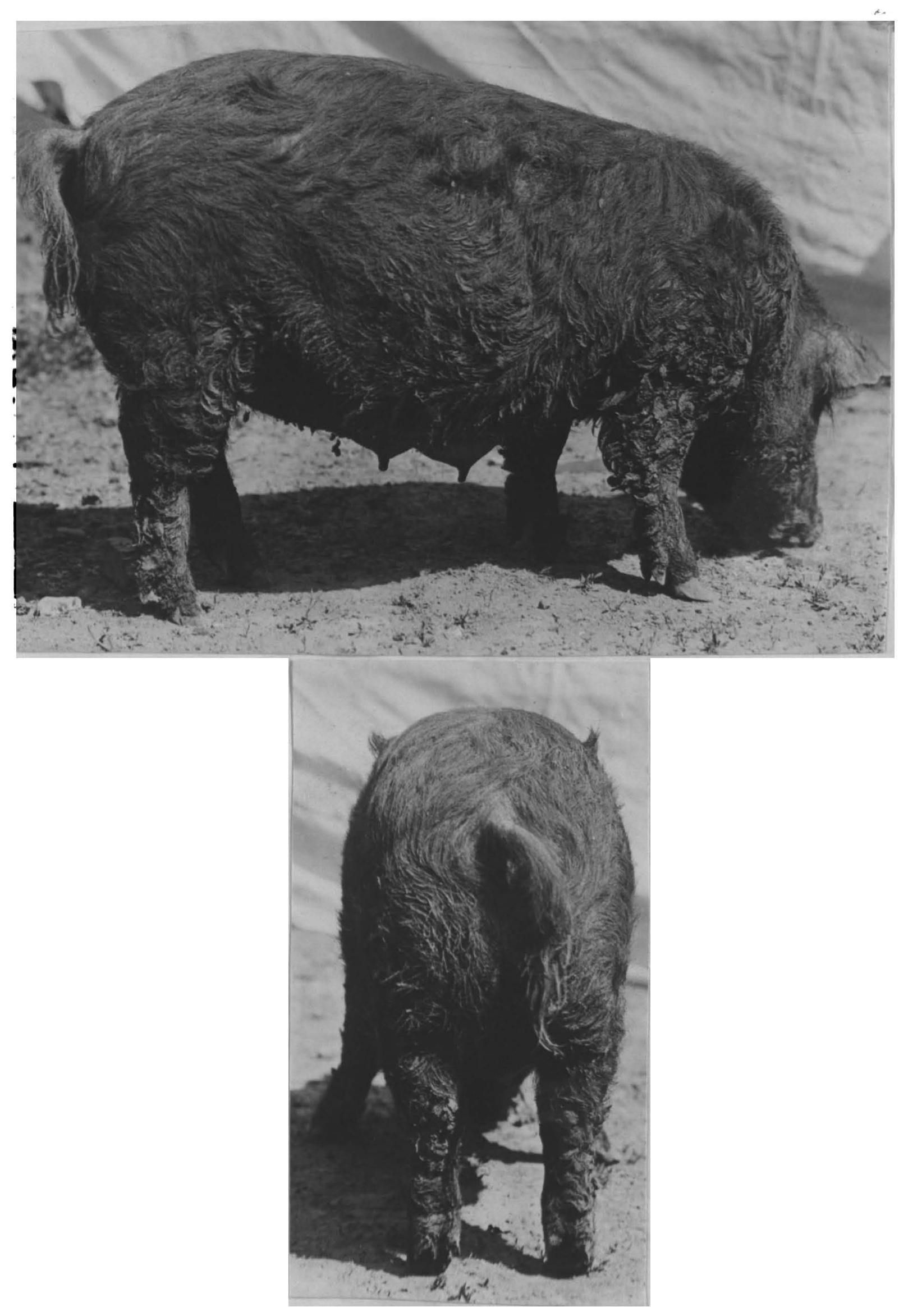




\section{Gilt No.5.}

May 12,1915-14mo.12days



$$
\begin{gathered}
\text { Gilt No.6. } \\
\text { May, } 191915-13 \text { mo.18days }
\end{gathered}
$$
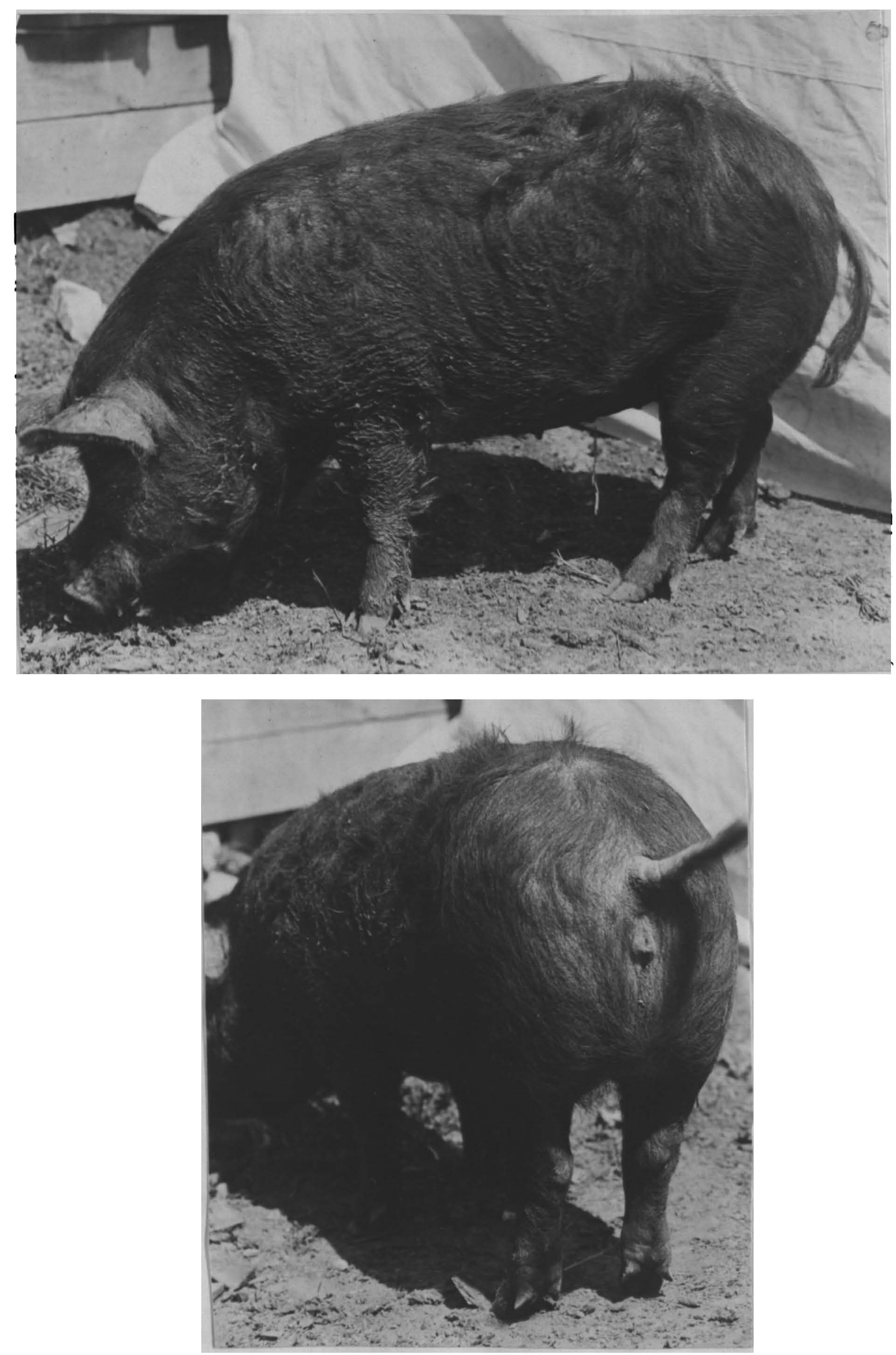


\section{Gilt No. 9.}

May 12,1915-14mo.5 days
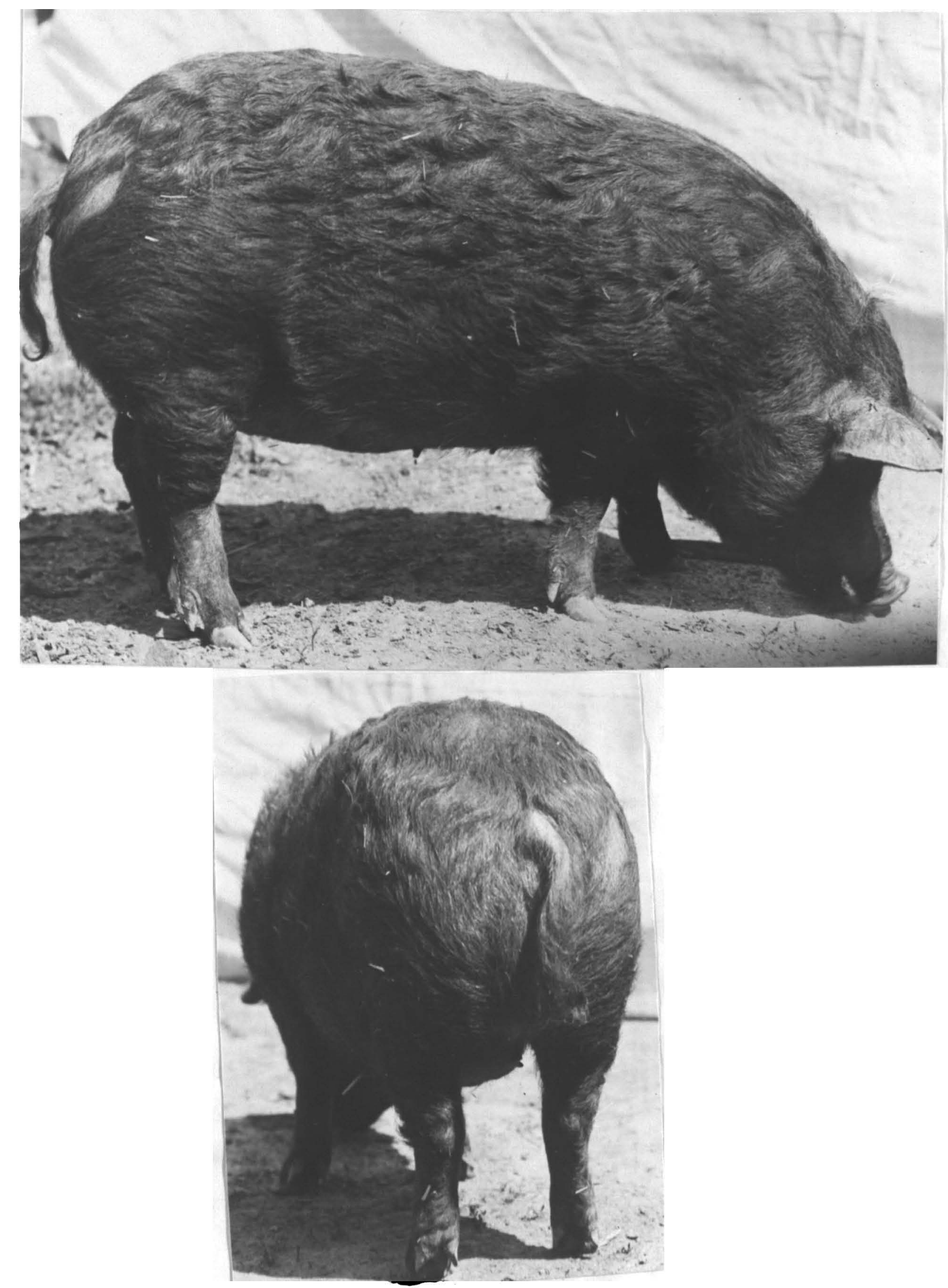
permit the catching of the droppings. The back 28 inches of the bottom of the crate is covered with tin. This allows the droppings to be recovered if they are not caught and prevents the urine from soaking into the boards. A tin pan 24 inches by 4 inches by 2 inches was placed under the rear end of each crate to catch any urine that might not be caught in the dippers. The front of the crate was closed by a sliding door which was raised to allow the animal to step forward to a trough placed at the front of the crate.

Four animals, two pregnant and two open, were placed In these crates in a room where the temperature could be controlled, January 22, 1915. The collection, for composite, of feces and urine began January 33rd. The animals were watched all the time and an effort made to catch all the feces and urine in dippers. Owing to the tendency of the four animals to act in unison, this was not always possible, and It sometimes was necessary to collect some of the feces from the tinned bottom of the crate, and to collect the urine from the tin pan under the rear end of the crate.

The weather was very cold and the temperature in the room thruout the trial was about $2^{\circ}$ to $6^{\circ} \mathrm{C}$. At first It was attempted to make the animals more comfortable by allowing them straw to lie on. It was found to be impossible to keep the straw away from the back part of the crate where the feces dropped if they were not caught, so the straw was all taken away before collections were begun. 
One dipper for feces and one for urine for each animal was marked and tared. Each weighing was recorded as gross weight that no errors would come from attempting to get the net weight. The feces were placed in a tared container with a close fitting lid. A record was kept of the time and amount of each defacation and urination. At 3:00 P. M. each day the weight of feces in the container was compared with the welght for the day as shown by the record to make sure no error had been made. The feces from each animal collected for the twenty four hours was thoroly mixed and an aliquot put in a container for the composite. for toy trtel. All containers for feces were rinsed out with a thymol solution.

At the close of the twenty four hour period the urine collected for the period was thoroly mixed and 50 cubic centimeters drawn off for the composite for analysis. Th1s did not give a true composite because the amount of urine volded varied from day to day, but since the digestion coefficient does not depend upon the urine, it was decided to use this plan rather than to add to the amount of labor at time of sampling. A little chloroform was added to the urine composite.

To see if there was any difference in the first and last parts of the ten-day trial, separate composites were made for the first and second five-day periods.

That the animals might be kept as nearly normal as possible each gilt was taken from her crate and driven about the room for fiftein to twenty minutes each day.

The four gilts were each given the ame amount, 5 pounds daily, of the same feed thruout the trial. This was 
the same amount they had been receiveng for elghteen days before the trial began.

All animals seemed to be in good health thruout the trial. All ate well and did not seem much distressed by the confinement and the small amount of exercise.

At the time of this digestion trial the two pregnant gilts had reached the sixty-ninth and seventy-second day of the per1od. That is to say, about six-tenths of the gestation period had passed.

It so happened that both open gilts were in heat at the beginning of the trial. They were, however, no more restless while this condition lasted than they were

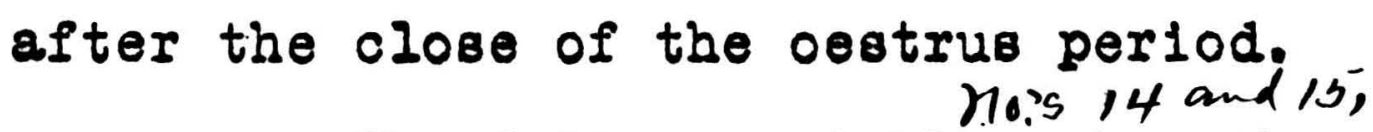

The following tableg, show the amount of feces and urine volded dally, the number of times of volding dally, and the average amount at one volding. The amounts of urine are seen to vary considerably from day to day for each animal. The total highest amount volded during the period was by a pregnant g1lt, and the next greatest arnount by an open one. In the number of times of volding there is a similar condition, except it is reversed for the groups. There seems to be no relation between the number of times of volding and the total amount. No. 5 with 39 voldings for the ten days yielded a greater amount than did No. 6 at 116 voldings. The frequency of volding may serve as an index of the restlessness of the animal. 


$$
\text { Table No. } 14
$$

Welght of Feces volded Daily
Ounces

Pregnant

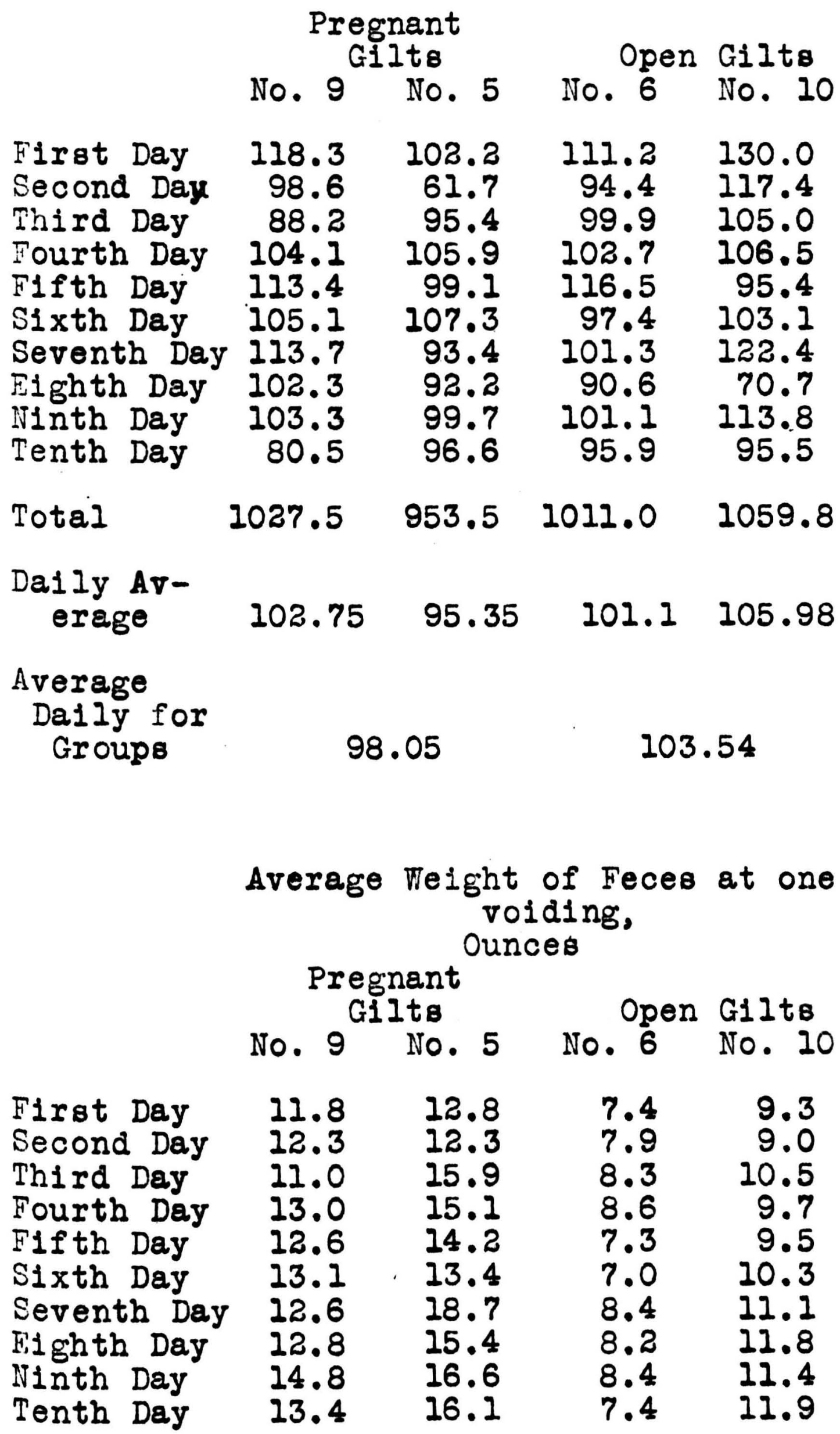

Number of times Feces were volded Daily

Pregnant Gilts Open Gilts No.6 No.10

10
8
8
8
9
8
9
8
7
6

$\begin{array}{rrr}8 & 15 & 14 \\ 5 & 12 & 13 \\ 6 & 12 & 10 \\ 7 & 12 & 11 \\ 7 & 16 & 10 \\ 8 & 14 & 10 \\ 5 & 12 & 11 \\ 6 & 11 & 6 \\ 6 & 12 & 10 \\ 6 & 13 & 8\end{array}$


Table no.15

Weight of Urine volded Dally,
Ounces

Pregnant

Gilts Open Gilts
Number of times Urine was volded Daily

\section{Pregnant}

Gilts

Open Gilts

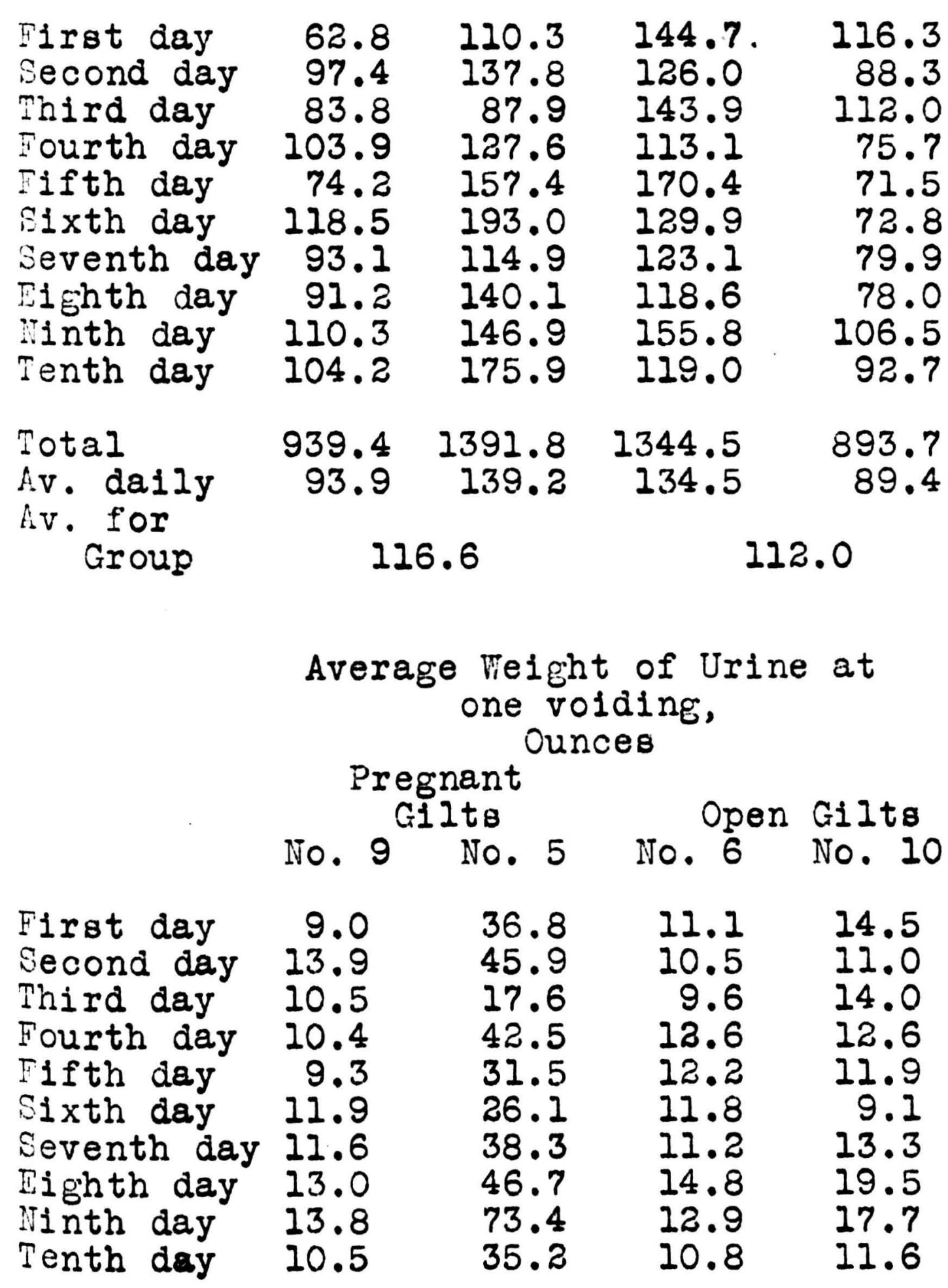


Thru the whole trial No. 5 was noticeably the most quiet and INo. 6 was decidedly the most restless.

Also in the amount of feces volded there are dally variations, and again the two animals volding the greatest amounts are not in the same group. In the number of times of volding the same two animals hold the places for greatest and least frequency--No. 5 with 64 for the ten days, and No. 6 with 129.

The urine analysis table, No.16, gives the percentages and welghts of solids, nitrogen, and ash in the urine. The averages show that the pregnant gilts gave of $f_{1} 18.8$ grams more solids, 1.0 gram less nitrogen, and 28.8 grams less of ash. Here again we fall to find consistency in the groups, except for the solids.

The analytical tables, Nos. 77,18 , and 9 , of the feces give the percentage of nutrients in the feces volded, the weights of nutrients volded, and a comparison of the amount of nutrients volded by the open and pregnant gilts.

There is found from a study of the table, No.18, of weights of nutrients in the feces the following!

(1) In the first five days three animals voided in the feces more dry matter, three volded more protein, two volded more fiber, three volded more ash, and all volded more nitrogen free extract than in the second five days of the trial. This was to be expected since confining them in the crates virtually reduces the amount of feed by depriving the animal of the chance to eat its own droppings. 


\section{Table No. 16}

Analysis of Urine.

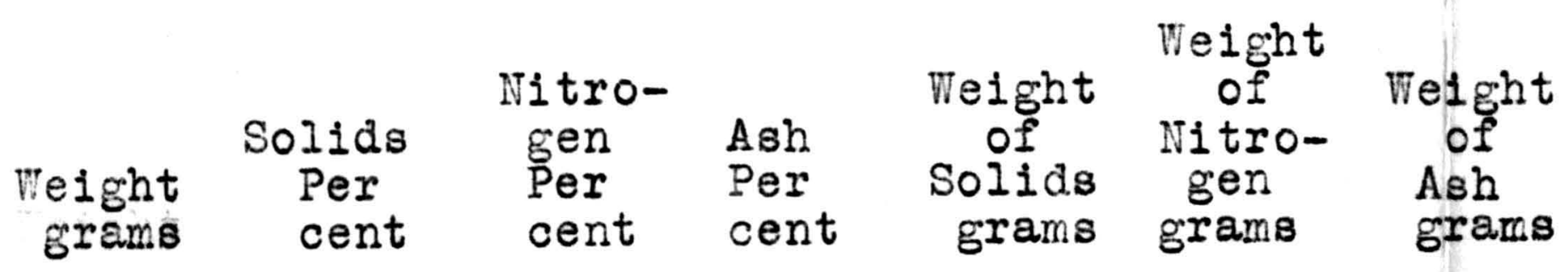

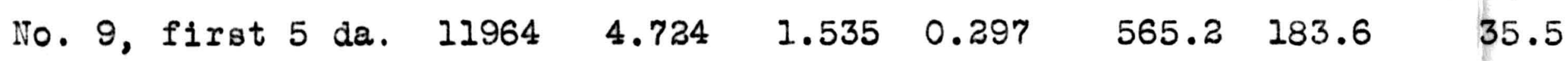

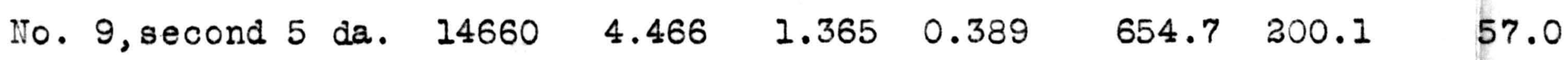

No. 9 , ten days $\quad \begin{array}{lllllll}26624 & 4.579 & 1.440 & 0.347 & 1219.9 & 383.7 & 92.5\end{array}$

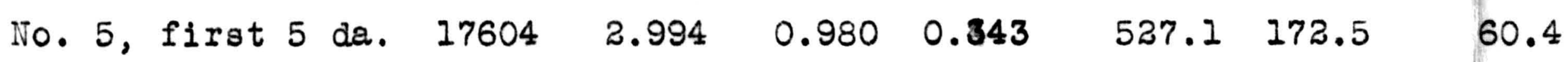

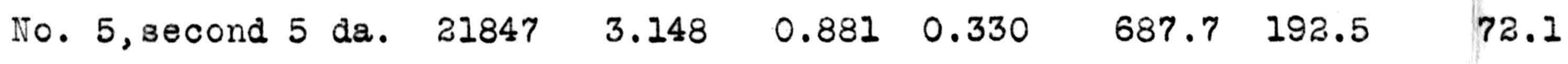

No. 5 , ten days $\quad \begin{array}{lllllll}39451 & 3.080 & 0.925 & 0.336 & 1214.8 & 365.0 & 132.5\end{array}$

No. 6, first 5 da. $\begin{array}{lllllll}19788 & 2.750 & 0.966 & 0.314 & 544.2 & 191.2 & 62.1\end{array}$

No. 6 , second 5 da. $\begin{array}{llllllll}18323 & 3.544 & 1.026 & 0.511 & 649.4 & 188.0 & 93.6\end{array}$

No. 6 , ten days $\quad \begin{array}{lllllll}38111 & 3.132 & 0.995 & 0.409 & 1193.6 & 379.2 & 155.7\end{array}$

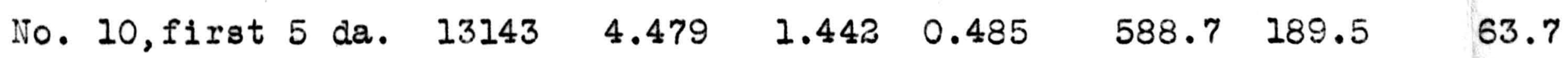

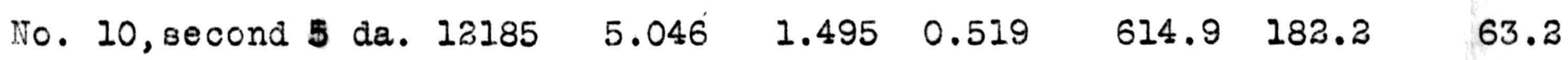

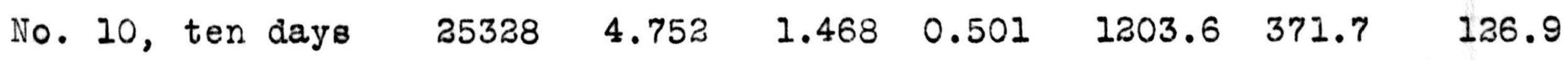

Average for Pregnant Animals, ten days

33038

Average for Open

Animals, ten days 31720
$1217.4 \quad 374.4 \quad 112.5$

$1198.6 \quad 375.5 \quad 141.3$ 
Tabie No. I?

Percentage Composition of Feces.

Animal*

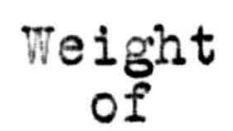

Feces

grams
Noisture Nitrogen

Per

Cent
Per

Cent
Crude

Fiber

Per
Ash N.E.E.

Per Per

Cent Cent

It No. 9, Ist $5 \mathrm{da} .14,813 \quad 77,610 \quad 0.572 \quad 1.704 \quad 4.0472 .858 \quad 10.206$

lt ivo. 9 , and 5 da. $14,310 \quad 77,760 \quad 0.547 \quad 2.076 \quad 3.863 \quad 2.826 \quad 10.056$

It io. 5 , let 5 da. $13,160 \quad 76.854 \quad 0.571 \quad 1.654 \quad 3.873 \quad 2.813 \quad 11.137$ it No. 5 , and 5 da. $13,866 \quad 77.216 \quad 0.602 \quad 2.212 \quad 3.9132 .769 \quad 10.12$ ?

lt No. 6, lst 5 da. 14,870 $77.018 \quad 0.632 \quad 1.925 \quad 3.7272 .666 \quad 10.714$

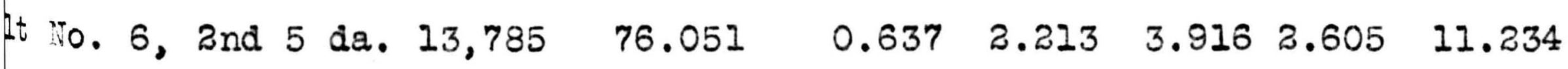

It No. 10, 1st 5 da. 15,712 $77.940 \quad 0.671 \quad 1.832 \quad 3.225 \quad 2.633 \quad 10.176$ It io. 10, 2nd 5 da. 14,330 $77.528 \quad 0.589 \quad 2.067 \quad 3.7102 .556 \quad 10.458$

'Nos. 9 and 5 pregnant. Nos, 6 and 10 open. 


$$
\text { Table no. } 18
$$

Weight of Nutrients in Feces, grams

$\begin{array}{lccccccc}\text { Imal* } & \begin{array}{c}\text { Weight } \\ \text { of } \\ \text { Feces }\end{array} & \begin{array}{c}\text { Dry } \\ \text { Matter }\end{array} & \begin{array}{c}\text { Protein } \\ (N \mathrm{X} 6.25)\end{array} & \text { Fat } & \begin{array}{c}\text { Crude } \\ \text { F1ber }\end{array} & \text { Ash } & \text { N.F.E. } \\ \text { Lst 5 da. } & 14,813 & 3316.6 & 529.4 & 252.4 & 599.5 & 423.4 & 1511.9 \\ \text { 3nd } 5 \text { da. } & 14,310 & 3182.5 & 489.4 & 297.1 & 552.8 & 404.4 & 1439.0 \\ \begin{array}{l}\text { for ten } \\ \text { yys }\end{array} & 29,123 & 6499.1 & 1018.8 & 549.5 & 1152.3 & 827.8 & 2950.9\end{array}$

$\begin{array}{lllllll}\text { Lst } 5 \text { da. } 13,160 & 3046.0 & 469.4 & 217.7 & 509.7 & 383.4 & 1465.6\end{array}$ ind da. $13,866 \quad 3159.2 \quad 521.9 \quad 306.7 \quad 542.6 \quad 383.9 \quad 1404.2$ for ten $\begin{array}{llllllll}\text { days } & 27,026 & 6205.2 & 991.3 & 524.4 & 1052.3 & 767.3 & 2869.8\end{array}$

lst 5 de. $14,870 \quad 3417.4 \quad 587.5 \quad 286.2 \quad 554.2 \quad 396.4 \quad 1593.2$ $\begin{array}{llllllll}\text { Ind } 5 \text { da. } & 13,785 & 3301.4 & 548.8 & 305.1 & 539.8 & 359.1 & 1548.6\end{array}$ for ten days 8 $28,655 \quad 6718.8 \quad 1136.3$ $591.3 \quad 1094.0 \quad 755.5 \quad 3141.8$

$\begin{array}{lllllll}\text {. lst } 5 \text { da. } 15,712 & 3466.1 & 658.8 & 287.8 & 506.7 & 413.7 & 1598.9\end{array}$ $\begin{array}{lllllll}\text {.2nd. } 5 \text { da. } 14,330 & 3220.2 & 527.5 & 296.2 & 531.6 & 366.3 & 1498.6\end{array}$ for ten $\begin{array}{llllllll}\text { days } & 30,042 & 6686.3 & 1186.3 & 584.0 & 1038.3 & 780.0 & 3097.5\end{array}$

*Nos, 9 and 5 pregnant, Nos, 6 and 10 open. 


\section{Table no. 19}

Comparison of weights of Nutrients in Feces from

Pregnant and Open Gilts.

Grams.

Weight
of

Feces Matter (N X 6.25) Fat Fiber Ash N.F.E.

$\begin{array}{llllllll}9 \text { Pregnant } & 29,123 & 6499.1 & 1018.8 & 549.5 & 1152.3 & 827.8 & 2950.9\end{array}$

$\begin{array}{llllllll}5 \text { Pregnant } & 27,026 & 6205.2 & 991.3 & 524.4 & 1052.3 & 767.3 & 2869.8\end{array}$

1 from

Pregnant

$\begin{array}{lllllll}56,149 & 12704.3 & 2010.1 & 1073.9 & 2204.6 & 1595.1 & 5820.7\end{array}$

age from

regnant

$\begin{array}{lllllll}38,075 & 6352.2 & 1005.1 & 537.0 & 1102.3 & 797.6 & 2910.4\end{array}$

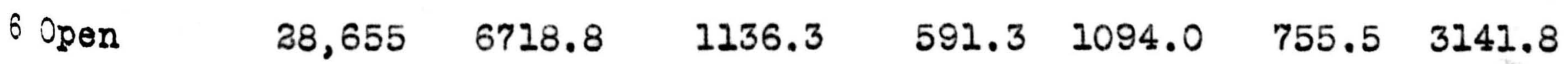

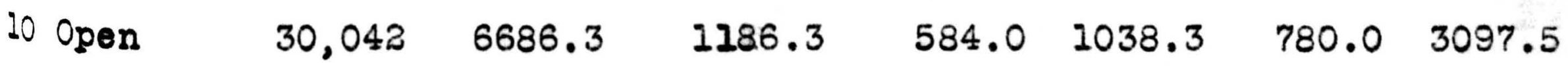

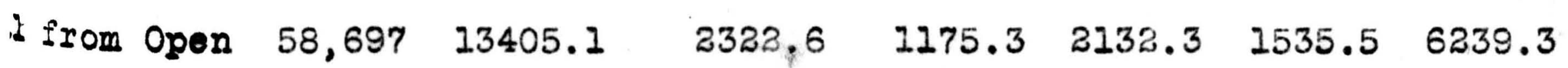

age from

ogen

$\begin{array}{lllllll}29,349 & 6702.6 & 1161.3 & 587.7 & 1066.2 & 767.8 & 3119.7\end{array}$

ase excess

reted by

in Gilts

$\begin{array}{llllll}350.4 & 156.2 & 50.7- & 36.1 & -29.8 & 209.3\end{array}$ 
(2) All animals volded more fat in second five days than in the first fire days. Did the confinement impair the ability to digest the fat? This would seem quite likely, but it does not seem to hold consistently for the other nutrients.

(3) The greater amount of ash excreted in the feces by each animal during the first five days of the trial is probably due in large measure to the animals' eating dirt while out in the pens; this of course was prevented by placing them in the crates.

In the table, No.19, showing a comparison of the total nutrients in the feces excreted by the pregnant and open animals it is seen that each pregnant gilt excreted less dry matter, protein, fat, and nitrogen freo extract than did either open animali. The average daily excess for an open gilt for the ten days 18 as follows: dry matter, 35.0 grams; protein, 15.62 grams; fat, 5.07 grame; and N. F. E., 20.93 grams.

In case of the crude fiber the groups are not consistent but the average amount excreted is highest for the pregnant gilts. The aame is true of the ash. The daily average excess bo: fiber, 3.61 grams; :ash, 2.98 grams. Since the amount of nutrients was the same for all animals, a smaller amount of any nutrient excreted by an animal means a larger amount of that nutrient digested by the animal; that is to say, a higher digestion coefficient. If these amounts be taken as average for the whole gestation period and compared with the amounts of constituents 
found by analysis in the largest litter we have the following:

$$
\begin{gathered}
\text { Weight Grams } \\
\text { Dry Watter Protein }
\end{gathered}
$$

Excess digested by

pregnant gilt

3994.6

1780.7

Constituents in

litter

1257.9

799.8

Excess digested over

amount in the litter

2736.7

980.9

This would look as if a pregnant gilt may, because of more efficient digestion, take enough more protein and dry matter from her food for the development of her litter.

The weight of each animal at beginning and close of table 20.

the digestion trial is givenin The welghts are three day averages.

Table no. 20

Pregnant Gilts Open Gilts

No. 9 No. 5 No. 6 No.10

Welght at beginning, pounds $223 \quad 230 \quad 180 \quad 192$

Welght at close, pounds

231

239

193201

Gain

8

9

13

9

The surprising thing here was the greater gain of Gilt No. 6. Her smaller size gave her more feed per hundred pounds live weight, but she was so much more restless than any other one that the opposite result was expected. From the data now avallable it does not appear that her digestion coefficlent can be much higher than that of the others. She volded in her feces more total dry matter than each of two of the others, 
more protein and crude fiber than each of two of the others, and more fat and nitrogen free extract than any other one.

Is her smaller weight and consequent lower maintenance cost sufficient to account for her greater gain? It may be possible to find an answer to this question when the analysis of the feed is completed. In addition to whatever amount the confinement may have impalred digestion it should not be forgotten that the digestion coefficient determined from this digestion trial will probably be too low to indicate the amount of nutriment actually digested by the animals In the pens where each had access to her droppings.

\section{Slaightering}

The animals were not stunned, but were hung up by the hind feet before bleeding, so they would bleed out well and all the blood could be caught. The scalding was done in a barrel and all hair and scurf carefully saved for analysis. After soraping and washing, the animal was opened and the internal organs removed. These organs were separated and each organ weighed. The stomach and intestines were emptied of their contents, cleaned and weighed, the weight of contents noted. The length of large and small intestines was measured. If intestines became smeared with the contents they were washed and carefully wiped with cloths.

After the removal of the internal organs the carcass was split in halves and hung up to chill before cutting up. 
The following gross cuts were made for each half: head, shoulder, side, and ham. Each cut was trimmed and the weight of the trimmed cut and trimmings recorded. All the cuts and trimmings from the right half of the animal were hand separated into akin, fat, lean, and bone, and weights of each taken. The area of the total skin sample was measured to determine surface area of the animal. The weights of the anatomical parts of the skeleton were obtained. In all the cutting, trimming, and separating, all parts were kept in closed containers except when actually being worked upon. All this work was done as rapidly as possible to keep down the $108 \mathrm{~s}$ from evaporation.

The trimmed cuts from the left side--shoulder, bacon, and ham--were cured for later comparison.

From a study of Table No.2/ of the weights of the internal organs is seen the large increase in weight of reproductive organs during pregnancy. Comparing the pregnant animals with the check, there is a suggestion that there may be an increase in the weight of intestines and liver due to pregnanoy.

Table No.12 gives weights of parts with the percentages of parts referred to the "'empty weight' of the animal. It was desired to use as the empty weight the weight of the live ainal less the weight of the contents of the stomach and intestines and the contents of the uterus. Since it was impossible to control the 108 s of urine and feces in scalding, this weight could not be ascertained by subtracting the weight of the con- 
Weights of Internal Organs of Gilts, pounds.

No. 4

Check

7 mo.

29 days
No. 7 88 days in In
0.70

0.15

0.90

0.30

0.20

1.70

2.15

0.40

0.65

2.40

0.25

0.35

0.10

0.35

0.27

0.10

Spinal Cord

Eyes and attend. $t$ issue
0.12
Uterus, Vagina,
Ovaries

Brain
No. 1 Before Farrowing $12 \mathrm{mo} 16 \mathrm{da}$
No. 3 After I2 mo.2
0.63

0.19

1.44

0.28

0.38

1.94

0.63

0.22

1.63

0.41

0.46

2.22

2.79

0.58

0.80

4.00

0.04

0.53

0.11

0.14

2.69

0.26

0.11

0.14

0.14

4.29

3.91

0.23

0.28

0.13

0.16

0.16

3.63

0.59

0.91

3.78

0.09

0.67
No. 10 Check da. 2 da. arrowing

$12 \mathrm{mo}$. 24 da.

0.58

0.60

0.20

0.17

1.38

1.38

0.41

0.29

0.34

0.26

1.85

1.89

2.35

3.19

0.57

0.61

1.11

0.90

3.05

3.72

0.04

0.03

0.62

0.45

0.11

0.16

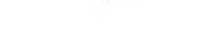




$$
\text { Table 20.22. }
$$

Weight of Parts of Gilts and Percentages of

Parts referred to the Empty Weight.

Pounda.

No. 4 No. 7 No. 1 No. 3 No. 8 No. 10

Live Weight at

Slaughtering

We1ght Hung Up

Weight Hair and Scurf

Welght of Blood

Total Weight

Weight Contents Digestive Tract

Teight Contents of jterue

Empty Weight

Per cent Empty Welght to Live Welght

Per cent Blood to Empty We1ght

Weight Internal Organs

Per Cent Internal Organs to Empty Welght

Weight Lean

Per cent Lean to Empty Weight

We1ght Fat

Per cent Fat to Empty

Weight Skin

$$
\text { We1ght }
$$

Per cent Skin to Empty Weight

Weight Bone

Per cent Bone to Empty Weight
163.500

256.000

257.000

248.000

245.000

224.000

151.950

239.500

243.000

234.500

233.450

214.250

2.440

5.170

4.030

4.100

5.000

3.620

5.650

9.450

9.240

9.300

7.550

6.630

160.040

254.120

256.270

247.900

14.600

22.270

18.730

$7.950 \quad 23.68$

145.440

223.900

213.860

24.700

1.25

221.950

83.210

89.500

94.330

91.240

3.885

4.221

4.321

4.190

3.267

3.244

11.990

18.740

19.950

19.720

17.170

15.190

8. 244

8.370

9.329

8.885

7.430

7.432

68.860

103.180

94.560

93.180

99.760

89.320

47.346

46.083

44.216

41.982

43.167

43.703

25.360

52.760

49.720

61.380

64.180

53.740
$17.437 \quad 23.564$

23.249

27.655

11.780

10.340

6.697

5.056

5.508

15.060

18.880

18.400

4.659

19.880

8.604

8.95

27.772

10.120

26.294

11.740

10.355
4.379

19.640

5.744

19.320

8.498

9.453 
tents found when the animal was opened from the weight before slaughtering. This 'empty weight' was determined as follows: to the weight of the animal after scalding and scraping was added the weight of the blood, hair and scurf, and toe's or hoofs, if they had been removed. In the table this sum is called the total weight, and from this total weight the weight of the contents of stomach, intestines, and uterus was subtracted. In no one of the ten animals slaughtered was any urine found in the urinary bladder. The empty weight found in this way is greater than the true empty weight by whatever welght of water has been added to the hair and scurf, but this weight is not large.

In percentace of blood to empty weight three of the producing gilts, Nos. 7, 1 , and 3, show a decldedly higher figure than do either of the checks, No. 4 or No. 10. (adipoutissue) In percentage of fat they are considerably higher than No. 4, slaughtered about 4 months earlier, and but little below No. 10, slaughtered at the same age. So difference in fatness does not account for this difference in percentage of blood. We should be inclined to think that perhaps in pregnancy a gilt increases the amount of her blood were it not for the fact that No. 8, another producing gilt, had about the same percentage as the older check, No. 10. It may be remarked here that the litter of No. 8 was delivered prematurely. The plgs were alive but did not Iive two days. Postmortem showed they had not reached normal development. 
In table No.23 a calculation was made of the weights of parts of the gilts at time of slaughtering the first check. Th1s calculation was based on the aseumption that at this time all animals were alike except in size. For instance, the slaughterhouse data showed that in the check animal the empty weight was 88.95 per cent of the live weight. Then if we assume that this percentage holds for each animal, the empty weight may be found by taking 88.95 per cent of Its live weight. Unquestionably these results do not represent the actual condition for there are individual differences in the animals that this method disregards.

For table No.24 these calculated weights were compared with the actual weights of the animals at slaughtering to determine the gains made. The inaccuracy of such a method of calculation has already been admitted, but if the results all point in the same difection there would appear to be some significance. While it is recognized that results that appear to be shown by such a calculation in the study of a few animals must be confirmed by wider studies, it does not seem reasonable to try to explain differences that appear to be consistent on the score of differences in the individuals, (without very positive evidence that such differences exist,) until a more extended study fails to confirm the results under consideration.

A comparison of the gain in weight of bone shows the gain by the open gilt was more than 30 per cent greater 


\section{$-64$ \\ Taple Nr.23.}

Theights of Parts of Gilts, Oct. 29, 1914

Calculated from Data on Gilt No. 4, Slaughtered Jct. 29, 1914. Pounds

No. 4 No. 7 No. 1 No. 3 No. 8 No. 10

Live Weight oct.

29, $1914 \quad 163.500 \quad 162.000 \quad 145.000 \quad 174.000 \quad 138.000 \quad 137.000$

Per cent Empty

Weight to Live

Weight

$\begin{array}{llllll}88.95 & 88.95 & 88.95 & 88.95 & 88.95 & 88.95\end{array}$

Empty We1ght

$\begin{array}{llllll}145.440 & 144.090 & 128.980 & 154.770 & 122.750 & 121.860\end{array}$

Per cent Blood

to Empty Weight

$\begin{array}{llllll}3.885 & 3.885 & 3.885 & 3.885 & 3.885 & 3.885\end{array}$

Welght of Blood

$\begin{array}{llllll}5.650 & 5.600 & 5.010 & 6.010 & 4.770 & 4.730\end{array}$

Per cent Internal

Organs to Empty

Weight

$8.244 \quad 8.244$

8.244

$8.244 \quad 8.244$

8.244

Weight of Internal Organs

$11.990 \quad 11.880$

10.630

12.760

$10.120 \quad 10.050$

Per cent Lean Flesh

to Empty Weight

$\begin{array}{llllll}47.346 & 47.346 & 47.346 & 47.346 & 47.346 & 47.346\end{array}$

We1ght of Lean Flesh/68.860

68.220

61.070

73.280

$58.120 \quad 57.700$

Per cent Fat to

Empty Weight

Welght of Fat

$\begin{array}{llllll}17.437 & 17.437 & 17.437 & 17.437 & 17.437 & 17.437\end{array}$

Per cent Skin to

Empty Weight

Weight of Skin

$25.360 \quad 25.120$

$22.490 \quad 26.99$

$21.4000 \quad 21.250$

Per cent Bone to

Empty Welght

$6.697 \quad 6.697$

6.697

6.697

6.697

6.697

9.740

9.650

$8.640 \quad 10.360$

8.220

8.160

Weight of Bone

$\begin{array}{llllll}10.355 & 10.355 & 10.355 & 10.355 & 10.355 & 10.355\end{array}$

$\begin{array}{llllll}15.060 & 14.920 & 13.360 & 16.030 & 12.710 & 12.620\end{array}$ 
Table no. 24

Actual weights at Slaughtering, with Gains over

Calculated Weights, pounds.

\begin{tabular}{|c|c|c|c|c|c|}
\hline & $\begin{array}{c}\text { No. } 7 \\
88 \text { days } \\
\text { in } \\
\text { Pregnancy }\end{array}$ & $\begin{array}{c}\text { No. } 1 \\
\text { Before } \\
\text { Farrowing } \\
12 \text { mo.16 da. }\end{array}$ & $\begin{array}{l}\text { No. } 3 \\
\text { After } \\
\text { Farrowing } \\
\text { la mo. } \\
\text { 2 da. }\end{array}$ & $\begin{array}{l}\text { No. } 8 \\
\text { After } \\
\text { Farrowing } \\
\text { I2 mo. } \\
\quad 24 \text { da. }\end{array}$ & $\begin{array}{l}\text { No. } 10 \\
\text { Check } \\
12 \text { mo. } \\
2 \text { da. }\end{array}$ \\
\hline Live Weight & 356.00 & 257.00 & 248.00 & 245.00 & 224.00 \\
\hline Gain in Iive Weight & 94.00 & 112.00 & 74.00 & 107.00 & 87.00 \\
\hline Empty We1ght & 223.90 & 213.86 & 221.95 & 231.10 & 204.38 \\
\hline Gain in Empty Weight & 79.81 & 84.88 & 67.18 & 108.35 & 82.52 \\
\hline Welght of Blood & 9.45 & 9.24 & 9.30 & 7.55 & 6.63 \\
\hline $\begin{array}{l}\text { Gain in Weight of } \\
\text { Blood }\end{array}$ & 3.85 & 4.23 & 3.29 & 2.78 & 1.90 \\
\hline $\begin{array}{l}\text { We1ght of Internal } \\
\text { Organs }\end{array}$ & 18.74 & 19.95 & 19.72 & 17.17 & 15.19 \\
\hline $\begin{array}{l}\text { Gain in Weight of } \\
\text { Internal Organs }\end{array}$ & 6.86 & 9.32 & 6.96 & 7.05 & 5.14 \\
\hline Weight of Lean Flesh & 103.18 & 94.56 & 93.18 & 99.76 & 89.32 \\
\hline $\begin{array}{l}\text { Gain in Feight of } \\
\text { Lean Flesh }\end{array}$ & 34.96 & 33.49 & 19.90 & 41.64 & 31.62 \\
\hline Woight of Fat Flesh & 52.76 & 49.72 & 61.38 & 64.18 & 53.74 \\
\hline $\begin{array}{c}\text { Gain in We1ght of } \\
\text { Fat Flesh }\end{array}$ & 27.68 & 27.23 & 34.39 & 42.78 & 32.49 \\
\hline We1ght of Skin & 11.32 & 11.78 & 10.34 & 10.12 & 11.74 \\
\hline $\begin{array}{l}\text { Gain in weight of } \\
\text { Skin }\end{array}$ & 1.67 & 3.14 & -0.02 & 1.90 & 3.58 \\
\hline Weight of Bone & 18.88 & 18.40 & 19.88 & 19.64 & 19.32 \\
\hline $\begin{array}{c}\text { Gain in Weight of } \\
\text { Bone }\end{array}$ & 3.96 & 5.04 & 3.85 & 6.93 & 6.70 \\
\hline
\end{tabular}


than any producing gilt except Gilt No. 8 which, on account of late breeding, had about 30 per cent more time than any of the others. This appears to indicate that with the conditions under which these animals were kept, the increase In weight of skeleton of a gilt is retarded by gestation. While it cannot be proved that this apparent difference does not come from crediting Gilt No. 10 with less weight of skeleton than she actually had at the beginning of the period, yet she has never been judged to have a noticeably heavier bone than the others.

The greater gain in weight of internal organs of the producing gilts is what would naturally be expected because of the great increase in weight of uterus. The greater gain in weight of blood of the same animals is in line with the greater per cent of blood to empty weight.

The gains in live weight do not occur in the same order as the gains mentioned above, the check animal making a smaller gain than any producing gilt except No. 3.

\section{Chemical Analyots}

The Samples Analyzed

The amples for analysis were blood, hair, and scurf, skin and toes, internal organs, lean, fat, and bone. The skin, lean, fat, and bone were from the right side of the animal. From the left side were taken the following special samples: lean loin from just back of last rib, subdermal fat from back at. withers, and a sample of the kidney fat. Analysis was made of the placenta and amniotic fluid of the 
two slaughtered before parturition; also of the pigs of these two animals, as well as two pigs born alive and killed before they had received any nourlshment.

\section{Obtaining the Samples}

Blood: Wile the animal was bleeding, blood was caught in a beaker and poured at once into tared receptacles provided with tight covers. These were at once taken to the laboratory and weighed to obtain an accurate weight of the fresh samples.

Hair and scurf: This sample consists of all the hair and scurf, collected from the scalding barrel and from the table and floor where the scraping was done. The water was drained from the scalding barrel and the hair and scurf collected; all excess water was squeezed out. The molst welght obtained, tho, for this sample is too high, but it was not possible to determine the exact weight on the animal. Since the amount of the constituents is computed from the percentage composition on the basis of this molst welght no error is introduced. There is in the hair more or less dirt which increases the ash in this sample. Internal organs: This term is used for the sample made up, except as noted, of the following: tongue, oesophagus, stomach, intestines, liver, gall bladder and gall, spleen, pancrea, kidneys, ovaries, uterus, vagina, urinary bladder, heart, pericardium and large arterles, diaphragm, lungs, brain, spinal cord, and eyes. 
Skin and toes: This sample consists of the skin from the entire right side of the animal, and the toes or hoofs from the right side. The right ear, entire, was inciuded.

Lean: the lean sample consists of all the hand separated lean from the right side. This necessarily contains some fat. The rule is for no lean to be left with the fat.

Fat: This sample consists of all the hand separated fat (adipose tissue) from the head, shoulder, side, and ham of the right side, together with one-half the internal fat.

Bone: This ample consists of all the bones from the right side of the animal, including half the tail and half the larynx, trachea, and tongue bones. Also the teeth from the right half of the head. No attempt was made to remove the tendons from the bones. A very little flesh was also left on the bones because its complete removal would require so much time that the error from increased evaporation would exceed that introduced by leaving this very small amount on the bones, Grinding Samples.

Each sample except the blood and the bone was Eround thru a coarse knife of an electrio Enterprise meat grinder, thoroly mixed, ground thru a finer knife, mixed and quartered down, and mixing and grinding continued, 
using finer knives, until the material was ground very fine and made as nearly uniform thruout as possible. The bones were ground thru a Hann's poultry bone cutter and mixed as thoroly as possible. Large samples of bone were taken for molsture and preliminary fat determination, after which the samples were finely ground for complete analyeis.

Thruout the separating, grinding and mixing all cuts, samples, and parts of samples were kept in closed containers as much as possible to reduce the loss from evaporation. The samples were kept in a cold room until weighed for analysis. A composite of all parts of the animal was made for ash analysis.

\section{Analyse日}

The analyses were made in triplicate according to methods adopted by the American Association of Official Agricultural Chemists. Determinations of molsture, nitrogen, fat, ash, and phosphorus were made on all the regular samples, except that no fat determinations were made on the blood. Analyses at the Missouri Experiment Station of many samples of blood of cattle have shown the amount of fat too small to be determined by the ordinary method of ether extraction. It was assumed that the same is true of the blood of swine. The determinations of ash and phosphorus were not made on the special samples of lean and fat. 


$$
\text { no.s } 25 \text { to } 34 \text {. }
$$

In the following pages are the analytical tables $\wedge_{\wedge}$ for five gilts, one slaughtered as a check at the beginning of the experiment, one that was 88 days in pregnancy when slaughtered, one slaughtered the day before she was due to farrow, one just after farrowing, and a second check slaughtered at the same age as those farrowing. In these tables are given the weights of the samples, blood, hair and scurf, internal organs, fat flesh or adipose tissue, lean flesh, skin, and bone; the percentage composition of each sample as determined by chemical analysis; the weights of the constituents in each sample; and the percentage composition and weights of constituents of the total animal. In one gilt, No. I, a separate analysis was made of the uterus and vagina. The analysis of the litters, afterbirth, and amniotic fluid have not been completed.

Table No.35 Gives a comparison of the percentage composition of parts of the different animals. For the total animal the per cent of fat is higher in the older animals and the per cent of water lower. There is no evidence that this condition is due to pregnancy. On the contrary, the highest per cent of fat and the lowest per cent of water is found in the older check. The difference here is not great enough, however, to seem to be significant. The ash per cent is lower for older gilts, but somewhat higher for the older check than for the producing gilts. The per cent of nitrogen does not vary significantiy. 


\section{$76^{-}$}

$$
\text { Table No.25 }
$$

Percentage Composition, Gilt No. 4,

Slaughtered as check, age 7 mo., 29 days.

\begin{tabular}{|c|c|c|c|c|c|c|}
\hline $\begin{array}{l}\text { Designation } \\
\text { of part }\end{array}$ & $\begin{array}{l}\text { We1ght } \\
\text { grams }\end{array}$ & $\begin{array}{l}\text { Mo1s- } \\
\text { ture } \\
\text { Per } \\
\text { cent }\end{array}$ & $\begin{array}{l}\text { Nitro- } \\
\text { gen } \\
\text { Per } \\
\text { cent }\end{array}$ & $\begin{array}{l}\text { Fat } \\
\text { (Ether } \\
\text { sol.) } \\
\text { Per } \\
\text { cent }\end{array}$ & $\begin{array}{l}\text { Ash } \\
\text { Per } \\
\text { cent }\end{array}$ & $\begin{array}{l}\text { Phos- } \\
\text { phorus } \\
\text { Per } \\
\text { cent }\end{array}$ \\
\hline Blood & 2563 & 77.850 & 3.511 & $*$ & 0.682 & 0.060 \\
\hline $\begin{array}{l}\text { Hair and } \\
\text { Scurf }\end{array}$ & 1107 & 58.111 & 6.512 & 0.604 & 1.668 & 0.080 \\
\hline $\begin{array}{r}\text { Intermal } \\
\text { Organs }\end{array}$ & 5439 & 66.975 & 2.599 & 13.438 & 1.125 & 0.188 \\
\hline $\begin{array}{c}\text { Skin and } \\
\text { Toes }\end{array}$ & 4509 & 45.829 & 4.517 & 27.144 & 0.513 & 0.049 \\
\hline Skeleton & 6831 & 40.517 & 3.201 & 15.418 & 22.982 & 4.167 \\
\hline $\begin{array}{c}\text { Adipose } \\
\text { Tissue }\end{array}$ & 11503 & 13.930 & 0.654 & 81.632 & 0.200 & 0.035 \\
\hline Lean & 31234 & 69.378 & 2.920 & 13.796 & 0.960 & 0.168 \\
\hline $\begin{array}{l}\text { Total } \\
\text { Animal }\end{array}$ & 63186 & 54.422 & 2.487 & 26.452 & 3.180 & 0.563 \\
\hline
\end{tabular}

* Not determined. Analyses of many samples of blood of cattle show the amount of fat too small to be determined by ordinary method of ether extraction. 


\section{7.}

$$
\text { Table no.26 }
$$

Wolght of Constituents in grams---Gilt No. 4, Slaughtered as check, age 7 mo., 29 days.

\begin{tabular}{|c|c|c|c|c|c|}
\hline $\begin{array}{l}\text { Designation } \\
\text { of Part }\end{array}$ & $\begin{array}{c}\text { Dry } \\
\text { Substance }\end{array}$ & Nitrogen & $\begin{array}{l}\text { Crude } \\
\text { Fat } \\
\text { (Ether } \\
\text { sol.) }\end{array}$ & Ash & Phosphorus \\
\hline Blood & 567.7 & 90.0 & $*$ & 17.5 & 1.54 \\
\hline $\begin{array}{l}\text { Hals and } \\
\text { Scurf }\end{array}$ & 463.6 & 72.1 & 6.7 & 18.5 & 0.89 \\
\hline $\begin{array}{r}\text { Internal } \\
\text { Organs }\end{array}$ & 1796.1 & 141.4 & 730.8 & 61.2 & 10.22 \\
\hline $\begin{array}{l}\text { Skin and } \\
\text { Toes }\end{array}$ & 2442.4 & 203.7 & 1223.8 & 23.1 & 2.21 \\
\hline Skeleton & 4063.3 & 218.7 & 1053.2 & 1566.1 & 284.65 \\
\hline $\begin{array}{l}\text { Ad1 pose } \\
\text { TIssue }\end{array}$ & 9900.7 & 75.3 & 9390.2 & 33.0 & 4.03 \\
\hline Lean & 9564.5 & 912.0 & 4309.1 & 299.9 & 52.47 \\
\hline $\begin{array}{l}\text { Total } \\
\text { Animal }\end{array}$ & 38798.3 & 1713.1 & 16713.8 & 2009.3 & 356.01 \\
\hline
\end{tabular}

* Not determined. Analyses of many samples of blood of cattle show the amount of fat too small to be determined by ordinary method of ether extraction. 


$$
\begin{gathered}
77678 \\
\text { Table } \operatorname{la}_{2}{ }^{7}
\end{gathered}
$$

Percentage Composition, Gilt No.?,

\begin{tabular}{|c|c|c|c|c|c|c|}
\hline $\begin{array}{c}\text { Designation } \\
\text { of Part }\end{array}$ & $\begin{array}{l}\text { We1ght } \\
\text { grame }\end{array}$ & $\begin{array}{l}\text { Mols- } \\
\text { ture } \\
\text { Per } \\
\text { cent }\end{array}$ & $\begin{array}{l}\text { Nitro- } \\
\text { gen } \\
\text { Per } \\
\text { cent }\end{array}$ & $\begin{array}{l}\text { Fat } \\
\text { (Ether } \\
\text { ool.) } \\
\text { Per } \\
\text { cent }\end{array}$ & $\begin{array}{l}\text { Ash } \\
\text { Per } \\
\text { cent }\end{array}$ & $\begin{array}{l}\text { Phos- } \\
\text { phosus } \\
\text { Per } \\
\text { cent }\end{array}$ \\
\hline Blood & 4286 & 78.054 & 3.708 & $*$ & 0.794 & 0.079 \\
\hline $\begin{array}{l}\text { Ha1r and } \\
\text { Sourf }\end{array}$ & 2345 & 60.033 & 6.298 & 0.646 & 2.207 & 0.061 \\
\hline $\begin{array}{r}\text { Internal } \\
\text { Organs }\end{array}$ & 8500 & 72.491 & 2.547 & 8.285 & 1.112 & 0.195 \\
\hline $\begin{array}{c}\text { Skin and } \\
\text { Toes }\end{array}$ & 5135 & 40.144 & 4.353 & 32.377 & 0.505 & 0.052 \\
\hline Skeleton & 8564 & 42.182 & 2.943 & 20.200 & 17.803 & 3.397 \\
\hline $\begin{array}{l}\text { Adipose } \\
\text { T1 s8ue }\end{array}$ & 23931 & 12.778 & 0.498 & 84.649 & 0.188 & 0.033 \\
\hline Lear & 46801 & 64.148 & 3.035 & 15.355 & 0.970 & 0.175 \\
\hline $\begin{array}{l}\text { Total } \\
\text { Animal }\end{array}$ & 99562 & 49.887 & 2.549 & 31.694 & 2.240 & 0.407 \\
\hline
\end{tabular}

88 days in pregnancy, age 11 mo., 26 days.

* Not determined. Analyses of many samples of blood of cattle show the amount of fat too small to be determined by ordinary method of ether extraction. 


$$
\text { Table no. } 28
$$

Weight of Constituents in grams---Gilt No.?,

88 days in pregnancy, age 11 mo., 26 days.

\begin{tabular}{|c|c|c|c|c|c|}
\hline $\begin{array}{l}\text { Designation } \\
\text { of Part }\end{array}$ & $\begin{array}{c}\text { Dry } \\
\text { Substance }\end{array}$ & Nitrogen & $\begin{array}{l}\text { Crude } \\
\text { Fat } \\
\text { (Ether } \\
\text { Bol.) }\end{array}$ & Ash & Phosphorus \\
\hline Blood & 940.7 & 158.9 & * & 34.0 & 3.39 \\
\hline $\begin{array}{l}\text { Hair and } \\
\text { Scurf }\end{array}$ & 937.3 & 147.7 & 15.3 & .51 .8 & 1.43 \\
\hline $\begin{array}{r}\text { Internal } \\
\text { Organs }\end{array}$ & 2338.3 & 216.5 & 704.2 & 94.5 & 16.57 \\
\hline $\begin{array}{c}\text { Skin and } \\
\text { Toes }\end{array}$ & 3073.4 & 223.5 & 1662.4 & 25.9 & 2.67 \\
\hline Skeleton & 4951.4 & $=252.0$ & 1729.9 & 1524.6 & 290.91 \\
\hline $\begin{array}{l}\text { Adipose } \\
\text { Tissue }\end{array}$ & 20873.5 & 119.2 & 20257.7 & 45.0 & 7.90 \\
\hline Lean & 16779.3 & 1420.4 & 7186.3 & 454.0 & 81.90 \\
\hline $\begin{array}{l}\text { Total } \\
\text { Animal }\end{array}$ & 49893.8 & 2538.2 & 31555.7 & 2229.8 & 404.77 \\
\hline
\end{tabular}

* Not determined. Analyses of many samples of blood of cattle show the amount of fat too small to be determined by ordinary method of ether extraction. 


$$
\text { Table no. } 29
$$

Percentage Composition, Gilt No. 1,

Slaughtered just before farrowing, age 12 mo., 16 days.

\begin{tabular}{|c|c|c|c|c|c|c|}
\hline $\begin{array}{c}\text { Designation } \\
\text { Of Part }\end{array}$ & $\begin{array}{r}\text { Weight } \\
\text { grams }\end{array}$ & $\begin{array}{l}\text { Mols- } \\
\text { ture } \\
\text { Per } \\
\text { cent }\end{array}$ & $\begin{array}{l}\text { Nitro- } \\
\text { gen } \\
\text { Per } \\
\text { cent }\end{array}$ & $\begin{array}{l}\text { Fat } \\
\text { (Ether } \\
\text { sol.) } \\
\text { Per } \\
\text { cent }\end{array}$ & $\begin{array}{l}\text { Ash } \\
\text { Per } \\
\text { cent }\end{array}$ & $\begin{array}{l}\text { Phos- } \\
\text { phorus } \\
\text { Per } \\
\text { cent }\end{array}$ \\
\hline Blood & 4191 & 78.968 & 3.377 & * & 0.744 & 0.078 \\
\hline $\begin{array}{l}\text { Hair and } \\
\text { Sourf } \\
\text { Internal or- } \\
\text { gans (less } \\
\text { uterus and } \\
\text { vagina) }\end{array}$ & 1828 & 56.584 & 7.012 & 9.524 & 1.103 & 0.072 \\
\hline $\begin{array}{c}\text { Skin and } \\
\text { Toes }\end{array}$ & 5343 & 39.357 & 4.756 & 30.773 & 0.534 & 0.058 \\
\hline Skeleton & 8346 & 38.000 & 2.961 & 23.591 & 19.074 & 3.541 \\
\hline $\begin{array}{l}\text { Adipose } \\
\text { Tissue }\end{array}$ & 23553 & 9.547 & 0.589 & 70.502 & 0.143 & 0.029 \\
\hline Lean & 42891 & 59.794 & 2.856 & 20.957 & 0.837 & 0.163 \\
\hline $\begin{array}{l}\text { Uterus and } \\
\text { Vagina }\end{array}$ & 1946 & 84.601 & 2.077 & 5.828 & 0.814 & 0.117 \\
\hline $\begin{array}{l}\text { Total } \\
\text { AnImal }\end{array}$ & 94200 & 52.632 & 2.498 & 31.006 & 2.290 & 0.423 \\
\hline
\end{tabular}

* Not determined. Analyses of many samples of blood of cattle show the amount of fat too small to be determined by ordinary method of ether extraction. 


$$
\text { Table no. } 30
$$

Welght of Constituents in grams, ----Gilt No. 1,

Slaughtered just before farrowing, age $12 \mathrm{mo}, 16$ days.

\begin{tabular}{|c|c|c|c|c|c|}
\hline $\begin{array}{c}\text { Designation } \\
\text { of Part }\end{array}$ & $\begin{array}{c}\text { Dry } \\
\text { Substance }\end{array}$ & Nitrogen & $\begin{array}{l}\text { Crude } \\
\text { Fat } \\
\text { (Ether } \\
\text { sol.) }\end{array}$ & Ash & Phosphorus \\
\hline Blood & 881.5 & 141.5 & $*$ & 31.2 & 3.27 \\
\hline $\begin{array}{l}\text { Hair and } \\
\text { Scurf } \\
\text { Internal Orgas } \\
\text { (Iess Uterus } \\
\text { Vagina) }\end{array}$ & $\begin{array}{l}793.6 \\
\text { ns } \\
\text { and } \\
2103.1\end{array}$ & 128.2 & 676.5 & 20.0 & $\begin{array}{r}1.32 \\
16.76\end{array}$ \\
\hline $\begin{array}{c}\text { Skin and } \\
\text { Toes }\end{array}$ & 3240.3 & 254.1 & 1644.3 & 28.5 & 3.10 \\
\hline Skeleton & 5174.6 & 247.1 & 1968.9 & 1591.9 & 295653 \\
\hline $\begin{array}{l}\text { Adipose } \\
\text { T1seue }\end{array}$ & 20399.4 & 132.8 & 15900.0 & 32.3 & 6.54 \\
\hline Lean & 17344.9 & 1225.0 & 8988.7 & 359.0 & 69.91 \\
\hline $\begin{array}{l}\text { Uterus and } \\
\text { Vag1 na }\end{array}$ & 399.7 & 40.4 & 27.5 & 15.8 & 2.38 \\
\hline $\begin{array}{l}\text { Total } \\
\text { Animal }\end{array}$ & 50136.1 & 2358.7 & 29208.3 & 2157.1 & 398.71 \\
\hline
\end{tabular}

* Not determined. Analyses of many samples of blood of cattle show the amount of fat too small to be determined by ordinary method of other extraction. 


\section{2 \\ Table no.}

Percentage Composition, Gilt No. 3,

Slaughtered just after farrowing, age 12 mo., 2 dgys.

\begin{tabular}{|c|c|c|c|c|c|c|}
\hline $\begin{array}{c}\text { Designation } \\
\text { of Part }\end{array}$ & $\begin{array}{l}\text { We1ght } \\
\text { grams }\end{array}$ & $\begin{array}{l}\text { Mo1s- } \\
\text { ture } \\
\text { Per } \\
\text { cent }\end{array}$ & $\begin{array}{l}\text { Nitro- } \\
\text { gen } \\
\text { Per } \\
\text { cent }\end{array}$ & $\begin{array}{l}\text { Fat } \\
\text { (Ether } \\
\text { sol.) } \\
\text { Per } \\
\text { cent }\end{array}$ & $\begin{array}{l}\text { Ash } \\
\text { Per } \\
\text { cent }\end{array}$ & $\begin{array}{l}\text { Phos- } \\
\text { phorus } \\
\text { Per } \\
\text { cent }\end{array}$ \\
\hline Blood & 4218 & 80.776 & 3.935 & * & 0.823 & 0.074 \\
\hline $\begin{array}{l}\text { Halr and } \\
\text { Sourf }\end{array}$ & 1960 & 60.606 & 6.582 & 0.627 & 1.318 & 0.063 \\
\hline $\begin{array}{r}\text { Internal } \\
\text { Organs }\end{array}$ & 8945 & 73.814 & 2.474 & 8.425 & 1.179 & 0.181 \\
\hline $\begin{array}{c}\text { Skin and } \\
\text { Toes }\end{array}$ & 4690 & 39.333 & 5.093 & 29.913 & 0.542 & 0.063 \\
\hline Skeleton & 9017 & 36.262 & 2.934 & 23.675 & 20.902 & 3.863 \\
\hline $\begin{array}{l}\text { Adipose } \\
\text { TIssue }\end{array}$ & 27841 & 11.915 & 0.526 & 84.724 & 0.200 & 0.041 \\
\hline Lean & 43266 & 64.001 & 2.974 & 16.881 & 0.888 & 0.149 \\
\hline $\begin{array}{l}\text { Total } \\
\text { Animal }\end{array}$ & 98937 & 47.181 & 2.450 & 35.403 & 2.534 & 0.451 \\
\hline
\end{tabular}

* Not determined. Analyses of many samples of blood of cattle show the amount of fat too small to be determined by ordinary method of ether extraotion. 


$$
\text { Table no.32 }
$$

Welght of Constituents in grams, Gilt No. 3, Slaughtered just after farrowing, age $12 \mathrm{mo}, 2$ days.

\begin{tabular}{|c|c|c|c|c|c|}
\hline $\begin{array}{c}\text { Designation } \\
\text { of Part }\end{array}$ & $\begin{array}{c}\text { Dry } \\
\text { Substance }\end{array}$ & Nitrogen & $\begin{array}{l}\text { Crude } \\
\text { Fat } \\
\text { (Ether } \\
\text { sol.) }\end{array}$ & Ash & Phosphorus \\
\hline Blood & 810.9 & 166.0 & $*$ & 34.7 & 3.12 \\
\hline Hair and & 771.9 & 129.0 & 13.3 & 25.8 & 1.23 \\
\hline Internal & 2343.3 & 221.3 & 716.8 & 105.5 & 16.19 \\
\hline $\begin{array}{c}\text { Skin and } \\
\text { Toes }\end{array}$ & 2845.4 & 238.9 & 1403.0 & 25.4 & 2.91 \\
\hline Skeleton & 5747.5 & 264.6 & 2134.9 & 1884.8 & 348.34 \\
\hline Adipose & 24534.1 & 146.5 & 23588.3 & 55.7 & 11.41 \\
\hline Lean & 15315.2 & 1357.4 & 7134.8 & 375.3 & 62.98 \\
\hline \multicolumn{6}{|l|}{$\begin{array}{l}\text { Total } \\
\text { Animal }\end{array}$} \\
\hline $\begin{array}{l}\text { * Not d } \\
\text { cattle show } \\
\text { ordinary met }\end{array}$ & $\begin{array}{l}\text { ermined. } \\
\text { amount } \\
\text { of ethe }\end{array}$ & $\begin{array}{l}\text { Analyses } \\
\text { fat too } \\
\text { xtractio }\end{array}$ & $\begin{array}{l}\text { of many } \\
\text { small to } \\
\text { on. }\end{array}$ & $\begin{array}{l}\text { samples } \\
\text { be dete? }\end{array}$ & $\begin{array}{l}\text { of blood of } \\
\text { mined by }\end{array}$ \\
\hline
\end{tabular}




$$
\begin{gathered}
84 \\
\text { Table no.33 }
\end{gathered}
$$

Percentage Composition, Gilt No. 10,

\begin{tabular}{|c|c|c|c|c|c|c|}
\hline $\begin{array}{c}\text { Designation } \\
\text { of Part }\end{array}$ & $\begin{array}{r}\text { Weight } \\
\text { grams }\end{array}$ & $\begin{array}{l}\text { Mols- } \\
\text { ture } \\
\text { Per } \\
\text { cent }\end{array}$ & $\begin{array}{l}\text { Nitro- } \\
\text { gen } \\
\text { Per } \\
\text { cent }\end{array}$ & $\begin{array}{l}\text { Fat } \\
\text { (Ether } \\
\text { sol.) } \\
\text { Per } \\
\text { cent }\end{array}$ & $\begin{array}{l}\text { Ash } \\
\text { Per } \\
\text { cent }\end{array}$ & $\begin{array}{l}\text { Phos- } \\
\text { phorus } \\
\text { Per } \\
\text { cent }\end{array}$ \\
\hline Blood & 3007 & 78.123 & 3.601 & * & 0.838 & 0.072 \\
\hline $\begin{array}{l}\text { lair and } \\
\text { Scurf }\end{array}$ & 1642 & 61.987 & 5.970 & 1.076 & 1.438 & 0.045 \\
\hline $\begin{array}{r}\text { Internal } \\
\text { Organs }\end{array}$ & 6891 & 71.880 & 2.600 & 8.653 & 1.207 & 0.189 \\
\hline $\begin{array}{c}\text { Skin and } \\
\text { Toes }\end{array}$ & 5325 & 51.201 & 4.282 & 23.833 & .0 .509 & 0.056 \\
\hline Skeleton & 8763 & 34.402 & 3.598 & 20.234 & 22.115 & 4.061 \\
\hline $\begin{array}{c}\text { Adipose } \\
\text { Tissue }\end{array}$ & 34376 & 10.827 & 0.447 & 88.712 & 0.193 & 0.054 \\
\hline Lean & 40515 & 63.151 & 2.963 & 18.032 & 0.961 & 0.188 \\
\hline $\begin{array}{l}\text { otal } \\
\text { Animal }\end{array}$ & 90518 & 46.715 & 2.473 & 35.999 & 3.799 & 0.513 \\
\hline
\end{tabular}

Slaughtered as check, age 12 mo., 2 days.

* Not determined. Analyses of many samples of blood of cattle show the amount of fat too small to be determined by ordinary method of ether extraction. 


$$
\begin{aligned}
& 85 \\
& \text { Table } 10.34
\end{aligned}
$$

Weight of Constituents in grams, Gilt No. 10, Slaughtered as check, age 12 mo., 2 days.

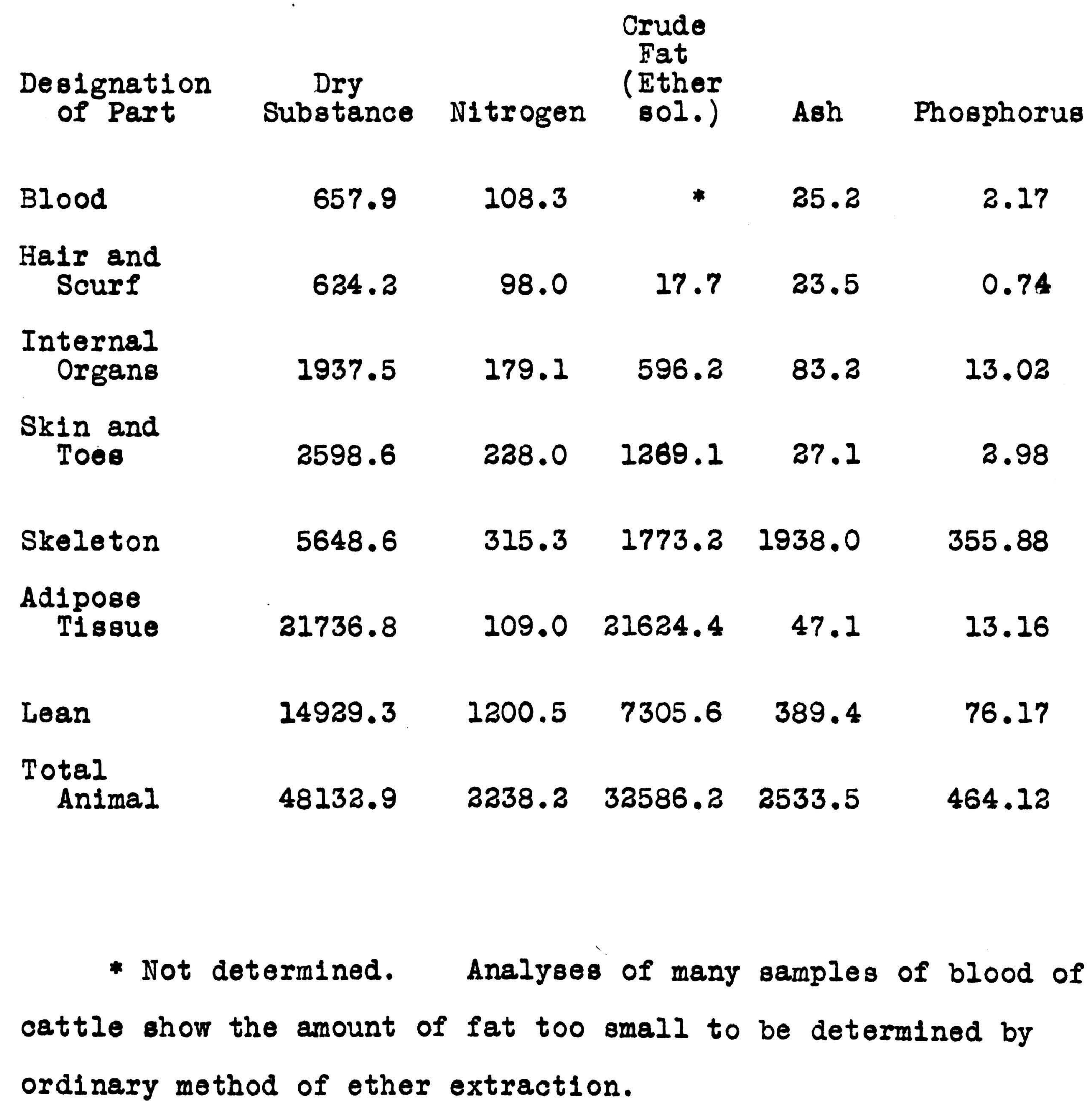




$$
\text { Table No.35- }
$$

Comparison of Percentage Composition of Parts of Different Animals.

$\begin{array}{ccccc}\text { No. } 4 & \text { No. } 7 & \text { No. } 1 & \text { No. } 3 & \text { No. } 10 \\ \text { Check } & 88 \text { days } & \text { Before } & \text { After } & \text { Check } \\ 7 \text { mo. } & \text { in } & \text { Farrowing Farrowing } & 12 \text { mo. } \\ 29 \text { da. Pregnancy } & 12 \text { mo.16 da. } 12 \text { mo.2 da. } & 2 \text { da. }\end{array}$

\begin{tabular}{|c|c|c|c|c|c|c|}
\hline Bone & Water & 40.517 & 42.182 & 38.000 & 36.262 & 34.402 \\
\hline Bone & Fat & 15.418 & 20.200 & 23.951 & 23.675 & 20.234 \\
\hline Bone & Ash & 22.982 & 17.803 & 19.074 & 20.902 & 22.115 \\
\hline Bone & Nitrogen & 3.201 & 2.943 & 2.961 & 2.934 & 3.598 \\
\hline $\begin{array}{c}\text { Internal } \\
\text { Organs }\end{array}$ & Water & 66.975 & 72.491 & 70.406 & 73.814 & 71.880 \\
\hline $\begin{array}{c}\text { Internal } \\
\text { Organs }\end{array}$ & Fat & 13.483 & 8.285 & 9.524 & 8.425 & 8.653 \\
\hline $\begin{array}{c}\text { Internal } \\
\text { Organs }\end{array}$ & Ash & 1.125 & 1.212 & 1.203 & 1.179 & 1.207 \\
\hline $\begin{array}{c}\text { Internal } \\
\text { Organs }\end{array}$ & Nitrogen & 2.599 & 2.547 & 2.585 & 2.474 & 2.600 \\
\hline $\begin{array}{l}\text { Lean } \\
\text { Flesh }\end{array}$ & Water & 69.378 & 64.148 & 59.794 & 64.001 & 63.151 \\
\hline $\begin{array}{l}\text { Lean } \\
\text { Flesh }\end{array}$ & Fat & 13.796 & 15.355 & 20.957 & 16.881 & 18.032 \\
\hline $\begin{array}{l}\text { Lean } \\
\text { Flesh }\end{array}$ & Ash & 0.960 & 0.970 & 0.837 & 0.888 & 0.961 \\
\hline $\begin{array}{l}\text { Lean } \\
\text { Flesh }\end{array}$ & Nitrogen & 2.920 & 3.035 & 2.856 & 2.974 & 2.963 \\
\hline $\begin{array}{l}\text { Total } \\
\text { Animal }\end{array}$ & Water & 54.422 & 49.887 & 52.632 & 47.181 & 46.715 \\
\hline $\begin{array}{l}\text { Total } \\
\text { Animal }\end{array}$ & Fat & 26.452 & 31.694 & 31.006 & 35.403 & 35.999 \\
\hline $\begin{array}{l}\text { Total } \\
\text { Animal }\end{array}$ & Ash & 3.180 & 2.240 & 2.290 & 2.534 & 2.799 \\
\hline $\begin{array}{l}\text { Total } \\
\text { Animal }\end{array}$ & Nitrogen & 2.487 & 2.549 & 2.498 & 2.450 & 2.473 \\
\hline
\end{tabular}


The high per cent of fat in the internal organs of the first check is perhaps due to rore fat being left on the organs than was the case with the other animals.

The greatest differences are found in the bone. The per cent of nitrogen is lower in the bone of the three producing gilts than in either of the checks. The percentage of fat in the bone is higher in two of the producing animals, while for weter the per cent is not consistent for the groups. The most striking difference, however, is found in the per cent of ash in the bone. The younger check has the highest per cent and all three producers fall below the older check. This would seem to indioate that pregnancy hinders the ossification of the skeleton. A comparison of the tro checks would also indicate that older animals have less ash in the bones. This is not ordinarily the case. Analyses of bones of many cattle at the Misouri Experiment Station show that the older cattle have a higher per cent of ash in the bone than do the younger ones. The analyois of the pigs is not completed; so that It 18 imposible to say with certainty, but a careful approximation of what may be expected leaves so wide a margin that it seems sure the weight of ash in the young added to that of the mother's bone will still leave the percentage lower than that of the checks.

This lower ash in the producing animals and in the older check may be due to insufficlent ash in the feed. Prior to the beginning of the experiment the gilts had had a ration much higher in ash than the one used here. The lower ash ration might be responsible for the animals' failing to put 
the same ratio of ash into the developing skeleton.

Table No.36, giving a comparison of the percentage composition of the internal organs, lean flesh, and total animal on the molbture- and fat-free basis, shows a higher percentage of phosphorus in the internal organs of the producing gilts, and lower in the lean flesh than is found in the flesh of the others. This suggests that a producing animal may concentrate phosphorus in the internal organs at the expense of her flesh.

On this basis of comparison the ash is again markedly lower for the producing than for the non-producing gilts. 


\section{9}

$$
\text { Table no.36 }
$$

Percentage Composition of Internal Organs, Lean Flesh, and Total Animal on Moisture- and Fat-Free Basis.

$\begin{array}{ccccc}\text { No. } 4 & \text { No. } 7 & \text { No. } 1 & \text { No. } 3 & \text { No. } 10 \\ \text { Check } & 88 \text { days } & \text { Before } & \text { After } & \text { Check } \\ 7 \text { mo. } & \text { in } & \text { Farrowing Farrowing } & 12 \text { mo. } \\ 29 \text { da. } & \text { Pregnancy } & 12 \text { mo.16 da. } 12 \text { mo.2 da. } & 2 \text { da. }\end{array}$

\section{Internal}



\section{Internal}

Organs Ash

5.744

5.784

5.496

6.639

6.200

\section{Internal}

Organs

Phosphorus

0.960

1.014

1.176

1.019

0.971

Lean

Flesh Nitrogen

17.354

14.807

14.837

15.556

15.746

Lean

Flesh Ash

5.705

4.731

4.348

4.645

5.107

Lean

Flesh Phosphorus

0.998

0.854

0.847

0.779

0.999

Total

Animal

Total

Animal Ash

16.627

12.161

13.996

14.550

16.192

Total

Animal

Phosphorus

2.944

2.210

2.585

2.589

2.968 
Discussion of Tables and Results of Lactation Period

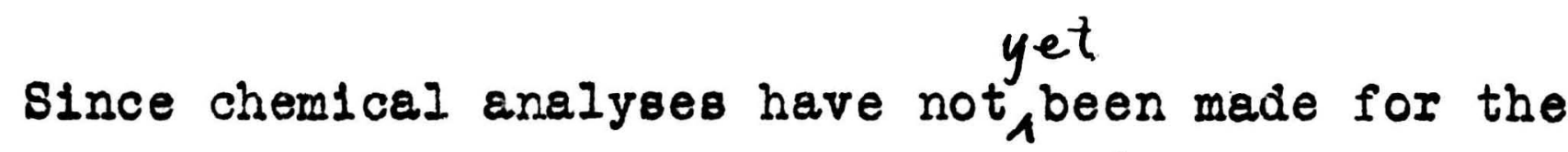
lactation period, the tables and discussions are based upan the records of feed consumed, live weights, measurements, and upon the slaughter house records.

A careful stuly of the feed record reveals the fact that in apite of the attempt to feed No. 5 more than any of the others, she actually ate less for the whole lactation perlod than any other one. The amounts comsumed by each animal, deducting for all feed refused, follow:

No. $6,391.3$ pounds; No. $9,382.0$ pounds; No. $2,393.5$ pounds; No. 5,368 pounds.

(When feed was refused the wet feed was taken to the laboratory, alcohol poured over it to prevent fermentation, and dried to air dry condition.)

Refusal of feed is responsible for different amounts recelved by Nos. 6,9 , and 3 .

Digestion Trial of Suckling and Non-Suckling Gilts.

April 27th a ten-day digeation trial was begun with the following animals: No. 5, suckling a litter of six plgs; No. 6 , a check that had never been bred, and No. 9 that had produced a litter but suckled for only elght days. (Nos. 5 and 9 were the pregnant gilts of the first digestion trial, and No. 6 was one of the open ones.) Th1s trial began 53 days after No. 9 had farrowed, and 48 days after the farrowing of No. 5. The pigs were allowed to suck six time every 
twenty four hours. There was a noticeable difference in the behavior of the animals. No. 5 had been the most quiet animal in the first digestion trial, but this time she was the most restless; while No. 6 , which had been decidedly the most restless in the first trial was the quietest this time, The restlessness of No. 5 was due in part at first to uneasiness on account of her pigs. After the first day or two, however, she seemed satisfied about them, but still. was more restless than either of the others. Thru this trial No. 5 received 6.2 pounds of feed dally; each of the others, 6.0 pounds. All the gilts gave indication of lack of mineral in their ration--trying when out of the crates to eat plaster from the wall.

\section{Table $\operatorname{No} 37$}

Weights of Animals at Beginning and Close of Digestion Trial. pounds, weights three day average.

$\begin{array}{lr}\text { No. } 5 & \text { No. } 9 \\ \text { Sucking } & \text { Without } \\ 6 \text { pigs } & \text { Lactation }\end{array}$

Weight at Beginning 198 264

Velght at Close Gain
195 $-3$ $\underline{279}$

15
No. 6 Check

The analytical work from this trial has not been completed. 
Table No. $3 \delta$ gives a comparison of the gains shown by the meavurements. These gains indicate that the check animal, No. 6, grew slightly more than did the gilt, No. 9, that had produced a litter but did not suckle the pigs. It should be remembered, however, that parturition came in this period and that she did suckle her pigs for elght days.

All except two of the measurements show a loss for No. 5. These two are only 0.5 centimeter gein, and such an apparent gain or loss is insignificant. No. 2 appears to have made but little if any growth.

The table of weighti, No.39, shows about the same gain for the check and No. 9. No. 2 just about maintained her welght thru the whole period, while No. 5 lost 60 pounds.

Table No.40 shows the length of intestines, the surface areas of the animals, and weighte fintermal for

Table No. 41 seems to indicate that the heart and lungs of the suckling animals are somewhat smaller than the others. The actual difference is small, 0.2 pound, but on a percentage basis the difference is worthy of note. It may be due wholly to individuality. The smaller amount of fat of the suckling gilts may account for the entire difference. It does not seem possible, however, that either or both those causes can be responsible for the great difference in weight of the uterus and vagina in the different animals. Th1s appears to be a shrinkage of the uterus due to lactation. 


\section{3}

$$
\text { Table } n_{0.38}
$$

Growth in Centimeters during the Lactation Period as shown by leasurements, Feb. 28 to hay 11.

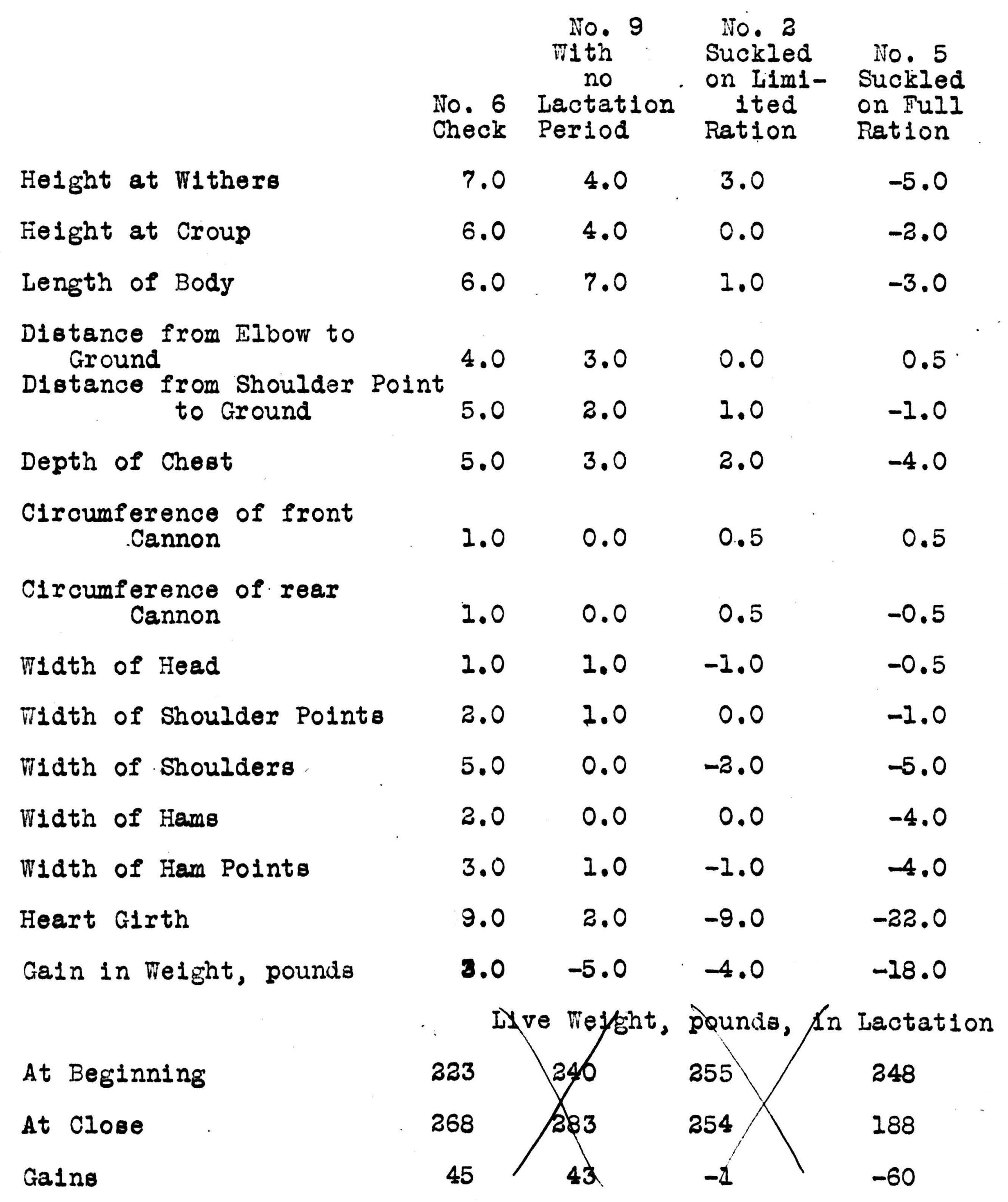


Table No. 39

Live Weight, in pounds, of Gilts thru

Iactation.

\begin{tabular}{|c|c|c|c|c|}
\hline & $\begin{array}{l}\text { No. } 6 \\
\text { Check }\end{array}$ & $\begin{array}{l}\text { No } 9 \\
\text { Without } \\
\text { Lactation } \\
\text { Period }\end{array}$ & $\begin{array}{l}\text { No. } 2 \\
\text { Suckled } \\
\text { on } \\
\text { Limited } \\
\text { Ration }\end{array}$ & $\begin{array}{l}\text { No. } 5 \\
\text { Suckied } \\
\text { on } \\
\text { Full } \\
\text { Ration }\end{array}$ \\
\hline Weight at Beginning & 223 & 240 & 255 & 248 \\
\hline Weight at Glose & 268 & 283 & 254 & 188 \\
\hline Gains & 45 & 43 & $-I$ & -60 \\
\hline
\end{tabular}

Table No. 40

Length of Intestines, Weight of Internal Fat,

and Surface Area of Animals.

$$
\text { No. } 6 \text { No. } 9 \text { No. } 2 \text { No. } 5
$$

Length of Small Intestines

c.m.

$1,512 \quad 1,641$

1,621

1,575

Length of Large Intestines c.m.

540

641

742

621

Weight of Internal Fat, Pounds

7.01

11.56

6.69

3.67

Surface Area, sq. c.m. 


\section{$95^{-}$ \\ Table no. 41}

Weight of Internal Organs of Gilts in Pounds

at Slaughtering.

\begin{tabular}{|c|c|c|c|c|}
\hline Age at Slaughtering & $\begin{array}{l}\text { No. } 6 \\
\text { Oheck } \\
\text { I3 mo. } \\
23 \mathrm{da} .\end{array}$ & $\begin{array}{l}\text { No. } 9 \\
\text { Without } \\
\text { Iacatation } \\
\text { Period } \\
\begin{array}{l}14 \mathrm{mo} . \\
5 \mathrm{da} .\end{array}\end{array}$ & $\begin{array}{l}\text { No. } 2 \\
\text { Suciled } \\
\text { on limi- } \\
\text { ted } \\
\text { Ration } \\
\text { I4 mo. } \\
23 \mathrm{da.}\end{array}$ & $\begin{array}{l}\text { No. } 5 \\
\text { Suckled } \\
\text { on FulI } \\
\text { Ration } \\
\frac{14 \mathrm{mo} .}{17 \mathrm{da} .}\end{array}$ \\
\hline Weight at Slaughtering & 266.00 & 284.00 & 250.00 & 188.00 \\
\hline Tongue & 0.66 & 0.82 & $0: 69$ & 0.72 \\
\hline Gullet & 0.19 & 0.22 & 0.17 & 0.16 \\
\hline Stomach & 1.34 & 1.73 & 1.67 & 1.45 \\
\hline Pancreas & 0.47 & 0.60 & 0.54 & $0.4 I$ \\
\hline Spleen & 0.36 & 0.39 & 0.24 & 0.25 \\
\hline Small Intestines & 2.14 & 1.85 & 2.60 & .11 \\
\hline Large Intestines & 2.69 & 3.28 & 3.81 & 3.00 \\
\hline Heart & 0.63 & 0.57 & 0.55 & 0.50 \\
\hline Lung:s & 0.91 & 0.96 & 0.77 & 0.73 \\
\hline Iiver & 4.04 & 4.16 & 4.29 & 3.16 \\
\hline Gall Bladder and Gall & 0.06 & 0.05 & 0.05 & 0.03 \\
\hline Kidneys & 0.67 & 0.56 & 0.55 & 0.52 \\
\hline Urinary Bladder & 0.13 & 0.14 & 0.13 & 0.13 \\
\hline Uterus, Vagina, and Ovaries & 81.44 & 1.69 & 0.36 & 0.34 \\
\hline Drain & 0.25 & 0.23 & 0.27 & 0.27 \\
\hline Spinal Cord & 0.17 & 0.11 & 0.16 & 0.15 \\
\hline Eyes and attend. tissue & 0.10 & 0.06 & 0.07 & 0.07 \\
\hline
\end{tabular}


The question arises as to the condition when a lactating animal becomes pregnant. Does the great increase in size of uterus check milk production, does milk production retard this increase of uterus, is another 'reserve capactity for assimflation'! aroused, or is this great increase in weight of uterus chlefly water and of little consequence so far as nutrition is concerned? We walt for the chemlcal. analysis to answer the last part of this question.

Table No.42 with the weights of parts and their percentages referred to the empty welght shows the reduction in fat due to lactation. The per cent of fat running as low as 14.311 in the case of No. 5, the per cent of fat in No. 2, the other lactating gilt, is 24.05 , only about one per cent lower than in No. 9 whlch was not producing milk. This seems to confirm our opinion that No. 2 was not producing much milk.

The higher per cent of internal organs observed in No. 5 is perhaps due entirely to the smaller amount of fat. Perhaps the most striking thing in this table is the small amount of intestinal fat in the lactating gilts.

Tables No., , and, give a comparison of the lactating gilts with two gilts, Nos. 3 and 8 , glaughtered after farrowing, and with Gilt No. 1, slaughtered just before farrowing. In the calculations for this table it is assumed that all these animals were just alike except in size at the time of farrowing, then the use of a factor determines the welght of any part of the live animal. The difference be- 
Tablen 20.42

Weights of Parts of Gilts and Percentages of Parta Referred to the Fmpty Wieight, pounas.

\begin{tabular}{|c|c|c|c|}
\hline קים & $\begin{array}{l}\text { No } 9 \\
\text { Without } \\
\text { Lactation }\end{array}$ & $\begin{array}{l}\text { No. } 2 \\
\text { Suckied } \\
\text { on iim- } \\
\text { ited. }\end{array}$ & $\begin{array}{l}\text { No. } 5 \\
\text { Suckieo } \\
\text { on Fuld }\end{array}$ \\
\hline 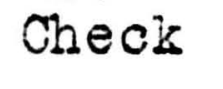 & Period & Ration & Ration \\
\hline $\begin{array}{l}13 \mathrm{mo} \\
23 \mathrm{da}\end{array}$ & $\begin{array}{l}\text { 14. mo. } \\
5 \text { da. }\end{array}$ & $\begin{array}{l}14 \mathrm{mo} . \\
20 \mathrm{da} .\end{array}$ & $\begin{array}{l}14 \mathrm{mc} \\
17 \mathrm{de}\end{array}$ \\
\hline
\end{tabular}

Live weight at glaughter-

$$
\text { ing }
$$

$266.00 \quad 284.00 \quad 250.00 \quad 188.00$

Weight Hung up

$256.00 \quad 270.00 \quad 240.00 \quad 179.00$

Wt. Hair, Scurf, and Toes

3.123 .40

3.10

3.80

Neight of Blood

$9.05 \quad 10.67$

7.60

7.34

Total Welght

Vielght of contents of Digestive Tract $268.17 \quad 284.07$ $240.70 \quad 290.14$ $29.70 \quad 24.88$

32.22

35.50

Empty Wejght

Per cent Fonpty Weight to Live Welght.

Per cent Blood to Enpty Weight $238.47 \quad 259.19$

208.48

154.64

$89.650 \quad 91.264 \quad 83.392 \quad 82.355$

$3.795 \quad 4.127$

3.645

4.747

Weight Internal Organs

Per cent Internal Organs to Impty Weight

$\begin{array}{cccc}17.63 & 18.86 & 18.65 & 15.14 \\ 7.393 & 7.277 & 8.946 & 9.790\end{array}$

Weight of Lean $112.16 \quad 119.15$

98.22

83.63

Per cent Lean to Fmpty Wt.

Weight of Fat

$$
62.9165 .31
$$

47.112

54.080

Per cent Fat to Fmpty Wt.

$26.381 \quad 25.198$

50.14

22.13

Weight Internal Fat

Per cent Internal Fat

to Empty Weight

$\begin{array}{cccc}7.01 & 11.57 & 4.87 & 3.44 \\ 2.940 & 4.461 & 2.336 & 2.226 \\ 11.70 & 13.40 & 11.65 & 9.87 \\ 4.906 & 5.170 & 5.588 & 6.324 \\ 20.58 & 22.26 & 22.42 & 21.44\end{array}$

Per cent Bone to Empty Weight 


\section{8 \\ Tables no,s 43,44, and 45-}

Weights in Pounds of Parts of Lactating Gilts, a calculated from

Iata on Gilts Slaughtered at Farrowing, and Gains over Calculated Weights.

\begin{tabular}{|c|c|c|c|c|c|c|c|}
\hline \multirow{5}{*}{$\begin{array}{l}\text { Ilve Weight* } \\
\text { Factor used in } \\
\text { calculations } \\
\text { Weight of Blood } \\
\text { Weight of Internal } \\
\text { Organs } \\
\text { Weight of Iean } \\
\text { Weight of Fat } \\
\text { Weight of Eone }\end{array}$} & \multirow[t]{2}{*}{$\begin{array}{l}\text { At } \\
\text { Actual } \\
\text { Welghts } \\
\text { No. } 3\end{array}$} & Calcu: & $\begin{array}{l}\text { lated } \\
\text { lohts }\end{array}$ & $\begin{array}{r}\text { A } \\
\text { Lac } \\
\text { Ac } \\
\text { Ve }\end{array}$ & $\begin{array}{l}\text { fter } \\
\text { tatiur } \\
\text { tuai } \\
\text { ights }\end{array}$ & \multicolumn{2}{|c|}{$\begin{array}{c}\text { Calculated } \\
\text { dains }\end{array}$} \\
\hline & & No. 2 & No. 5 & No. 2 & No. 5 & No. 2 & No. 5 \\
\hline & 248.00 & 255.00 & 248.00 & 250.00 & 288.00 & -5.00 & -60.00 \\
\hline & 9.30 & $\begin{array}{l}1.03 \\
9.58\end{array}$ & $\begin{array}{l}1.00 \\
9.30\end{array}$ & 7.60 & 7.34 & -1.98 & -1.96 \\
\hline & $\begin{array}{l}19.72 \\
93.18 \\
61.38 \\
19.88\end{array}$ & $\begin{array}{l}20.31 \\
95.98 \\
63.22 \\
20.48\end{array}$ & $\begin{array}{l}19.72 \\
93.18 \\
61.38 \\
19.88\end{array}$ & $\begin{array}{l}18.65 \\
98.22 \\
50.14 \\
22.42\end{array}$ & $\begin{array}{l}15.24 \\
83.63 \\
22.23 \\
21.44\end{array}$ & $\begin{array}{r}-1.66 \\
+2.24 \\
-13.08 \\
+1.94\end{array}$ & $\begin{array}{r}-3.58 \\
-9.55 \\
-39.25 \\
+1.56\end{array}$ \\
\hline & No. 8 & No. 2 & No. 5 & iro. 2 & 10. 5 & No. 2 & No. 5 \\
\hline $\begin{array}{l}\text { Live Weight } \\
\text { Factor used in }\end{array}$ & 245.00 & 255.00 & 248.00 & 350.00 & 188.00 & -5.00 & -60.0 \\
\hline $\begin{array}{l}\text { calculations } \\
\text { Weight of Ilood } \\
\text { Welght of Internal }\end{array}$ & 7.55 & $\begin{array}{l}1.04 \\
7.85\end{array}$ & $\begin{array}{l}1.01 \\
7.63\end{array}$ & 7.60 & 7.34 & -0.25 & -0.29 \\
\hline $\begin{array}{l}\text { Organs } \\
\text { We1ght of Iean } \\
\text { We1ght of Fat } \\
\text { We1ght of Bone }\end{array}$ & $\begin{array}{l}17.17 \\
99.76 \\
64.18 \\
19.64\end{array}$ & $\begin{array}{r}17.86 \\
103.75 \\
66.75 \\
20.43\end{array}$ & $\begin{array}{r}17.34 \\
100.76 \\
64.82 \\
19.84\end{array}$ & $\begin{array}{l}18.65 \\
98.22 \\
50.14 \\
22.42\end{array}$ & $\begin{array}{l}15.14 \\
83.63 \\
22.13 \\
21.44\end{array}$ & $\begin{array}{r}+0.79 \\
-5.53 \\
-16.61 \\
+1.99\end{array}$ & $\begin{array}{r}-2.20 \\
-17.13 \\
-42.69 \\
+1.60\end{array}$ \\
\hline & No. 1 & No. 2 & No. 5 & No. 2 & No. 5 & No. & No. 5 \\
\hline $\begin{array}{l}\text { Iive Weight } \\
\text { Factor used in }\end{array}$ & 257.00 & 255.00 & 248.00 & 250.00 & 188.00 & -5 & -60.00 \\
\hline $\begin{array}{l}\text { calculations } \\
\text { Welght of Blood } \\
\text { Welght of Internal }\end{array}$ & 9.24 & $\begin{array}{l}0.99 \\
9.15\end{array}$ & $\begin{array}{l}0.96 \\
8.87\end{array}$ & 7.60 & 7.34 & -3 & - \\
\hline $\begin{array}{l}\text { Organs } \\
\text { Weight of Lean } \\
\text { Weight of Fat } \\
\text { Weight of Bone }\end{array}$ & $\begin{array}{l}19.95 \\
94.56 \\
49.72 \\
18.40\end{array}$ & $\begin{array}{l}19.75 \\
93.61 \\
49.22 \\
18.22\end{array}$ & $\begin{array}{l}19.15 \\
90.78 \\
47.73 \\
17.66\end{array}$ & $\begin{array}{l}18.65 \\
98.22 \\
50.14 \\
22.42\end{array}$ & $\begin{array}{l}15.14 \\
83.66 \\
22.13 \\
21.44\end{array}$ & $\begin{array}{l}-1.10 \\
+4.61 \\
+0.92 \\
+4.20\end{array}$ & $\begin{array}{r}-4.01 \\
-7.12 \\
-25.60 \\
+3.78\end{array}$ \\
\hline
\end{tabular}

*Actual weight in all cases, used to obtain factor for calculation. Nos. 3 and 8 slaughtered just after farrowlng, $\%$. 1, just before farrowine. 
tween this calculated weight and the weight actually found in the animal at slaughter is considered gain or loss.

The results in this table, in so far as results thus obtained can be depended upon, indicate that No. 2 grew very little, if at all, and that No. 5 actually lost during lactation in weight of blood, internal organs, lean flesh, and fat flesh, showing gain in the skeleton only.

Is all this decrease in weight due to loss of fat, or is there an actual loss of protein? Studies at the Missouri Experiment Station of cattle on submaintenance rations show that when the animal is losing fat it draws very heavily on all other tissues before any fat is taken from the skeleton. This fact may help to explain the apparent gain in welght of okeleton in the case of this gilt even when she was losing weight. 


\section{Summary}

\section{The Experiment}

The experiment was started with ten similar gilts about seven months old, to study the effect of gestation and lactation on their growth and composition. One was slaughtered for analysis as a check at the beginning of the experiment. Seven were bred and two left open as checks. One pregnant gilt was slaughtered 88 days after conception, one just before farrowing, and two just after farrowing. One open gilt was slaughtered at this time. Two gilts suckled litters, one produced a litter but did not suckle it. Each of these was slaughtered 68 days after she farrowed and the last open gilt was slaughtered about the same time.

All animals were kept under as nearly the same conditions as possible till after farrowing when an attempt was made to give one suckling gilt a large ration, but as a matter of fact all did consume very nearly the same amount of feed.

Records were kept of dally weights, feed, measurements. At slaughtering the weights of organs and parts were recorded.

One digestion trial was run in each period for comparison of digestion coefficlent of open, pregnant, and suckling gilts. 
The Pesults

Welghts show no particular difference in the growth of the open and pregnant groups.

Measurements seem to favor a greater growth of open group, but this is not decided and may a.11 be due to individuality. The digestion trial indicates that the digestion coefficient of the pregnant gilts is enough higher than nutrients

the open to provide for the development of the litter.

The slaughterhouse data indicates that possibly

pregrancy may have caused an increase in the amount of blood and a retardation of skeletal growth.

The percentage composition indicates that pregnancy lowered the per cent of ash in the skeleton more than is accounted for by the ash in the litter.

Lactation greatly retarded growth and in case of one animal seems to have stopped it entirely except, possibly, in the skeleton.

\section{Conclusions}

In work with animals individuality is so large a factor that conclusions must be formed with caution except where large numbers are used. Then too, animals are so much affected by olight changes in environment and nutrition that all the conditions must be carefully considered. It frequently happens that there are conditions whose influence cannot be measured. 
In this experiment only ten animals were studied, and this number allows but few checks or repeats for any one condition. On this account we can say little more than that certain tendencies appear to be shown. Then, too, there is yet a large amount of the work unfinished, and the interpretation of the results already found may be changed when the work is completed.

At present the following conclusions seem tenable: Pregnant gilts make about as much growth as open gilts receiving the same feed.

Perhaps, with gilts running together, pregnancy promotes growth.

Lactation greatly retards growth and may poselbly stop it altogether. 


\section{Acknowledgements}

The investigation of which this thesis is a preliminary report has been made under the general direction of Dean F. B. Mumford and Dr. P. F. Trowbridge. Mr. I. A. Weaver selected the animals and advised as to their care. Mr. E. S. Matteson assisted in taking the measurements. A large part of the analytical work was done by the Station staff of the Department of Agricultural Chemistry. The writer wishes to acknowledge his indebtedness to all these men. 
104

References

(1) Davenport--Experimental Norphology, Part II, Intd.

(2), Ibd. Chapt. X.

(3) Marshall--Physiology of Reproduction, p. 494.

(4) M1not--Senescence and Growth--Jour. Phys101., V0I XII, 1891.

(5) Hensen--Arbe1ten Ke11, Phys101. Inst1t. 1868.

(6) Forbes--Oh10 Experiment Station Technical Bul.,5, pp.470 ff.

(7) Iusk--Science of Nutrition, pp. 232.

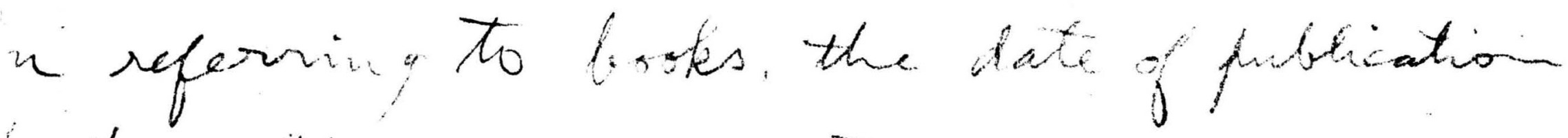
the ention are rivgertant 